\title{
The upper Katian (Ordovician) bryozoans from the Eastern Iberian Chains (NE Spain)
}

\author{
ANDREA JIMÉNEZ-SÁNCHEZ
}

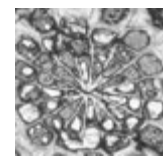

\begin{abstract}
The upper Katian (Upper Ordovician) bryozoans from the Iberian Chains (NE Spain) are described. Twenty-three species are identified, five of them are new, seven were already identified in other paleocontinents and Mediterranean localities, four are provisionally referred to other known species, and seven are undetermined species. All of them belong to 22 genera assigned to 14 families, and to one incertae sedis genera. The five Stenolaemata orders (Cryptostomata, Cyclostomata, Cystoporata, Fenestrata and Trepostomata) are represented here, Trepostomata and Cryptostomata being the most abundant and diverse. The trepostome family Halloporidae is the one with the highest diversity, with 4 genera and 5 species described here. The five new species are the cryptostomes Pseudostictoporella iberiensis sp. nov., characterized by the presence of superior hemisepta in the autozooecia, and Prophyllodictya javieri sp. nov., also characterized by the presence of superior hemisepta in the autozooecia and by its small exilazooecia; the cystoporate Ceramoporella inclinata sp. nov., whose main diagnostic character is the constant autozooecial inclination; and the trepostomates Dybowskites ernsti sp. nov., easily recognizable by its large autozooecial and mesozooecial apertures, as well as by its large acanthostyles and Trematopora acanthostylita sp. nov., mainly characterized by the absence of diaphragms in its mesozooecia and numerous, large acanthostyles. • Key words: Stenolaemata, Bryozoans, upper Katian, Upper Ordovician, Iberian Chains, NE Spain.
\end{abstract}

JiMÉNEZ-SÁNCHEZ, A. 2009. The upper Katian (Ordovician) bryozoans from the Eastern Iberian Chain (NE Spain). Bulletin of Geosciences 84(4), 687-738 (45 figures, 24 tables). Czech Geological Survey, Prague. ISSN 1214-1119. Manuscript received July 3, 2009; accepted in revised form October 27, 2009; published online December 18, 2009; issued December 31, 2009.

Andrea Jiménez-Sánchez, Área de Paleontología, Departamento de Ciencias de la Tierra, Universidad de Zaragoza, C/ Pedro Cerbuna 12, 50009 Zaragoza (Spain); andreaj@unizar.es

Bryozoans were one of the main invertebrate groups dominating the carbonate platforms during the Ordovician. They have been widely studied in North America, the Baltic and Scandinavian countries, Eastern Europe and Siberia, where they were strongly diversified by the Mid Ordovician. However, the Ordovician bryozoans from the Mediterranean margin of Gondwana have received much less attention in spite of their abundance in the Upper Ordovician carbonate units typical of the region. In the Cystoid Limestone Formation (Dereims 1898, Villas 1983), upper Katian (Upper Ordovician) in age, of the Iberian Chains (NE Spain), the five Stenolaemate orders, present since the Lower-Middle Ordovician transition, are represented [Cryptostomata, Cyclostomata, Cystoporata, Fenestrata and Trepostomata (Jiménez-Sánchez et al. 2007)]. This strongly contrasts with their extremely low diversity and very scarce occurrences in the underlying horizons. This fact is related to the Upper Ordovician environmental conditions, when the development of carbonate platforms on the Mediterranean margin of Gondwana allowed a massive faunal expansion (Vennin et al. 1998). Before the late
Katian and since the Mid Cambrian, the Mediterranean Region was occupied by large siliciclastic platforms (Gutiérrez-Marco et al. 2002).

The first descriptions of the Ordovician Mediterranean bryozoans are from Portugal (Sharpe 1853), Bohemia (Počta 1902, Kettner 1913, Röhlich 1957) and the Carnic Alps (Vinassa de Regny 1910, 1914, 1915, 1942), although this work now needs revision. The bryozoans occurring in rocks of the same age as the Cystoid Limestone Formation, from the Montagne Noire, France (Dreyfuss 1948, Boulange 1963, Ernst \& Key 2007), and Sardinia (Conti 1990), have already been well studied. The contributions of Buttler \& Massa (1996) and Buttler et al. (2007) describing a total of seven species in the Upper Ordovician of Libya, as well as the contributions of Termier \& Termier (1950) and Destombes et al. (1971) identifying five genera in the Upper Ordovician of Morocco must also be acknowledged. In addition to the first report of Upper Ordovician bryozoans in the Cystoid Limestone Formation by Hafenrichter (1979), who identified the genera Diplotrypa and Hallopora, the preliminary study of Jiménez-Sánchez et al. 


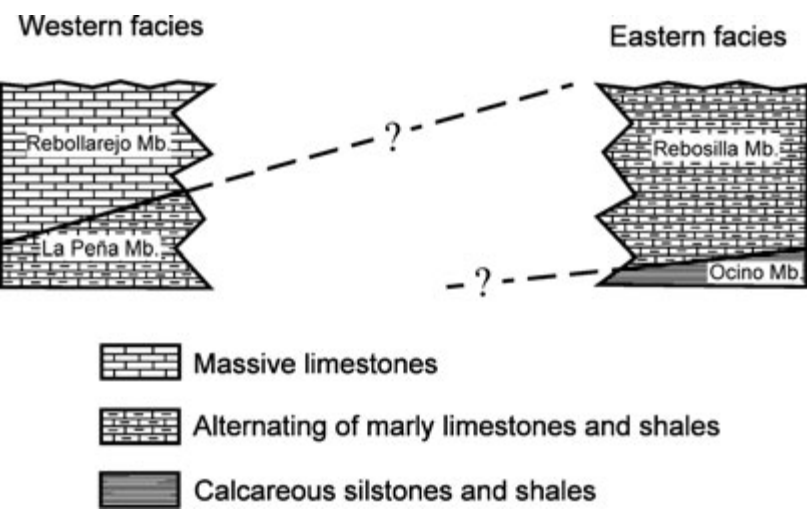

Figure 1. Relationships between facies and lithostratigraphic units of the Cystoid Limestone Formation. Taken from Jiménez-Sánchez et al. (2007).

(2007) should also be mentioned, in which 21 genera are added to those already known from the region. JiménezSánchez (in press) described five Monticuliporidae species found in the Cystoid Limestone Formation. JiménezSánchez \& Villas (in press) conducted a paleobiogeographic study of the upper Katian bryozoan faunas, incorporating the taxonomic data from previous papers and using multivariate statistical methods. Finally, JiménezSánchez et al. (in press) described a new genus and species from the family Rhinidictyidae using both the phenetic and cladistic systematic approaches.

The aim of the present study is to continue with the systematic description of the bryozoans from the Cystoid Limestone Formation, most of them preliminarily listed and figured in Jiménez-Sánchez et al. (2007). This study should contribute to knowledge of the Ordovician bryozoan fauna in the Mediterranean margin of Gondwana.

In this paper twenty three species are described, five of them are new, seven were already identified in other paleocontinents and Mediterranean localities, four are provisionally referred to other known species, and seven are undetermined species. All of them belong to 22 genera assigned to 14 families, and to one incertae sedis genera. The trepostome family Halloporidae is the one with the highest diversity, with 4 genera and 5 species described here.

A total of 29 species have now been identified in the Cystoid Limestone Formation, the orders Trepostomata, with 15 species (52\%), and Cryptostomata, with 9 species $(31 \%)$, are the most diverse. The other orders, Cystoporata (7\%), Fenestrata (7\%) and Cyclostomata (3\%), are in the minority. Thirteen of these species are restricted to the Mediterranean Province, in which India has also been included (Jiménez-Sánchez \& Villas in press). These species are Ceramoporella inclinata sp. nov., Chasmatopora hypnoides (Sharpe, 1853), Dybowskites ernsti sp. nov., Diplotrypa gemmata (Conti, 1990), Eridotrypa obliqua Conti, 1990, Iberostomata fombuenensis Jiménez-Sánchez et al., to be published, Monticulipora cystiphragmata Jiménez-Sánchez, in press, Prasopora carnica Vinassa de Regny, 1915, Prasopora spjeldnaesi Jiménez-Sánchez, in press, Prophyllodictya javieri sp. nov., Pseudostictoporella iberiensis sp. nov., Trematopora acanthostylita sp. nov., and Ulrichostylus radiatus Conti, 1990. Monticulipora kolaluensis Jaroshinskaja, 1962 was previously known exclusively from the Upper Ordovician of Altai Sayan. Ceramopora? lindströmi Hennig, 1908, was also known exclusively from the Lower Silurian of Gotland (Sweden). Pseudostictoporella iberiensis sp. nov. and Prophyllodictya javieri sp. nov. are the first representatives of their genera known outside the palaeocontinents of Laurentia, the former, and of Baltica and South China, the latter. Hallopora elegantula (Hall, 1851) and Kukersella borealis (Bassler, 1911) are the most widely distributed of all the species found in Cystoid Limestone Formation, both in space and time. Hallopora elegantula has been identified in the palaeocontinents of Avalonia, Baltica, Laurentia, Gondwana and Siberia, as well as in South China, in horizons from the Upper Ordovician to the Middle-Upper Silurian. Kukersella borealis is known from the palaeocontinents of Avalonia, Baltica, Gondwana and Laurentia, in horizons from the Middle to the Upper Ordovician.

\section{Geographical and geological setting}

A detailed description of the geographical and geological setting of the studied sections, as well as complete information regarding the stratigraphic and sedimentary characteristics of the Cystoid Limestone Formation, can be found in Villas (1985), Hammann (1992), Vennin et al. (1998), Jiménez-Sánchez et al. (2007) and Jiménez-Sánchez (in press).

The bryozoans described here have been collected from four sections of the Cystoid Limestone Formation: the Valdelaparra and La Peña del Tormo sections, near the village of Fombuena (Zaragoza), and the Luesma 2 and Luesma 3 sections, near the village of Luesma (Zaragoza). The formation was divided into four members according to lateral and vertical facies changes (Hammann 1992). In the western sections, Valdelaparra and La Peña del Tormo, the La Peña and the Rebollarejo members can be recognized; while in the eastern sections, Luesma 2 and Luesma 3, the Ocino and Rebosilla members can be recognized (Fig. 1). The distribution of the species in the studied sections and lithostratigraphic units is not homogenous (Fig. 2). The La Peña Member was the most productive, having yielded the 29 known species; in the Rebollarejo Member, three species only are represented, the same as in the Rebosilla Member; and the Ocino Member has not yet yielded any taxa. Valdelaparra 


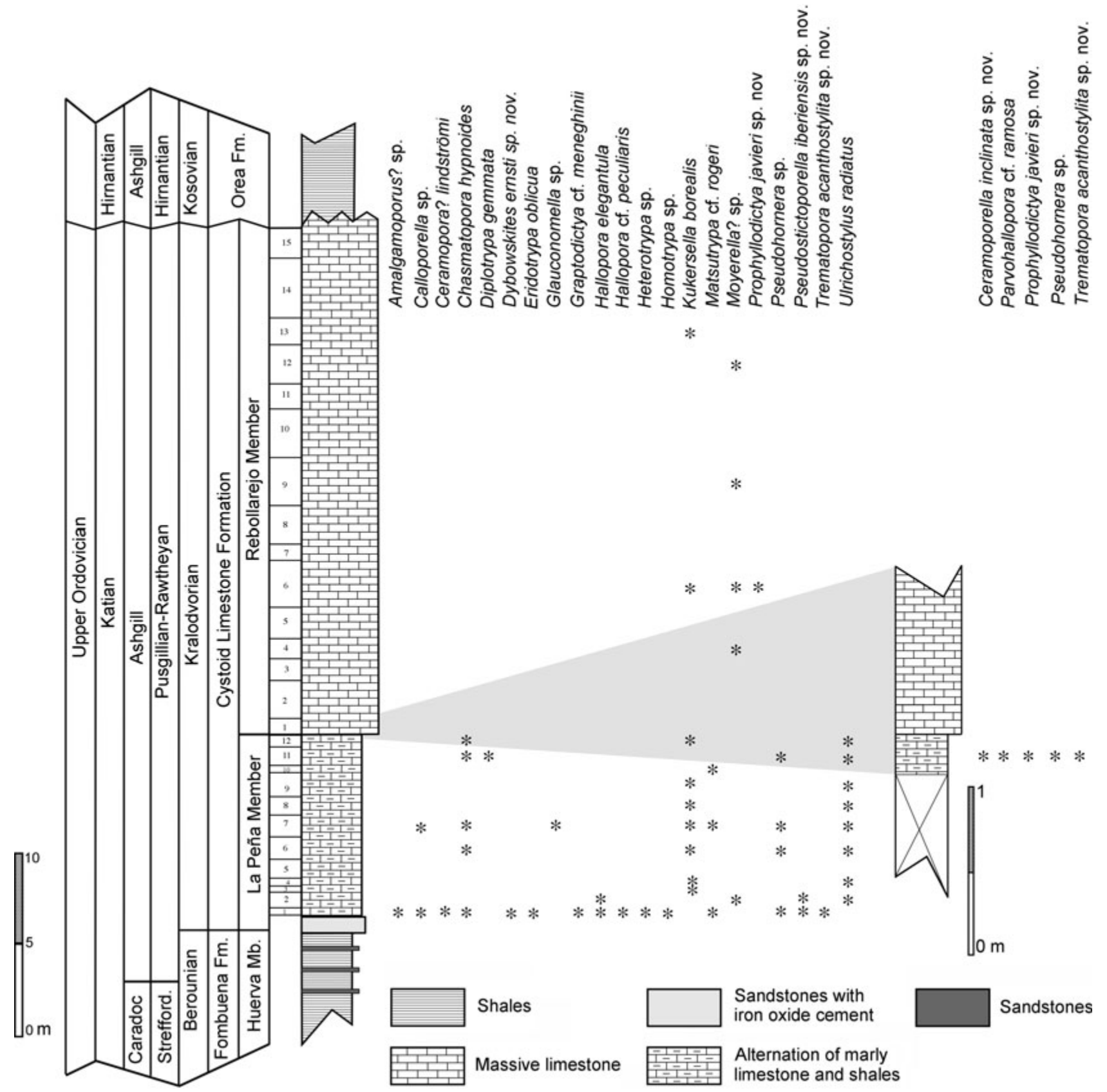

Figure 2. Stratigraphic distribution of the species described from the Valdelaparra (on the left) and the La Peña del Tormo (on the right) sections.

is the section with a higher bryozoan diversity, with 26 recognized species.

\section{Systematic palaeontology}

To carry out this systematic study, 219 thin sections were observed under a transmitted light microscope. The measurements were taken directly from the thin section using the microscope with a micrometer, or from scaled photog- raphs. The suprageneric classification is based on Karklins (1983) for the suborder Ptilodictyina, the web page: http://bryozoa.net/iba.html, edited by Phil Bock for the order Fenestrata and Ernst \& Key (2007) for the rest of orders, suborders and families. The material described here is housed in the Museo de Paleontología de la Universidad de Zaragoza, specimen numbers MPZ 2006/100-107, 111, 112, 114-116, 118-125, 127, 128, 135-162, 164-167, 169-184, 186, 188-197, 199-201, 203-230, 233-238, 240-251, 253, 255-258, 261-272, 274-290 and MPZ 2008/169. 
Phylum Bryozoa Ehrenberg, 1831

Class Stenolaemata Borg, 1926

Order Cryptostomata Vine, 1884

Suborder Ptilodyctyina Astrova \& Morozova, 1956

Family Escharoporidae Karklins, 1983

\section{Graptodictya Ulrich, 1882}

Type species. - Ptilodictya perelegans Ulrich, 1878. Waynesville Formation, Upper Ordovician of Clarkville (Ohio, USA).

\section{Graptodictya cf. meneghinii (Vinassa de Regny, 1942)} Figures 3A, B, 4, 5, Table 1

cf. 1942 Pachydictya meneghinii sp. nov.; Vinassa de Regny, pp. 1030, 1031, pl. 1, figs 6-8.

cf. 1942 Graptodictya sp.; Vinassa de Regny, p. 1030, pl. 1, figs $4,5$.

cf. 1942 Pachydictya (?) sardona sp. nov.; Vinassa de Regny, p. 1031, pl. 1, fig. 11 .

cf. 1988 Graptodictya sp.; Conti \& Serpagli, p. 143, pl. 11, fig. 5 , pl. 12, figs 2,3 .

cf. 1990 Graptodictya meneghinii (Vinassa de Regny, 1942). - Conti, pp. 113, 114, pl. 20, figs 5-7.

cf. 2007 Graptodictya meneghini (Vinassa de Regny, 1942).Ernst \& Key, p. 408, pl. 17, fig. 15, pl. 18, figs 1-3.

2007 Graptodictya sp.; Jiménez-Sánchez et al., fig. $7(5,6)$.

Material. - One zoarium (MPZ 2006/189) in tangential and longitudinal sections.

Description. - Zoaria branching and bifoliated, with a small diameter of $0.64 \mathrm{~mm}$ on average. Autozooecia of length equal to between three and four time its diameter, budding from the mesotheca, forming on average an angle of $44^{\circ}$, bending at the endozone-exozone limit and intersecting the external surface at an apparent angle of $71^{\circ}$ on average; autozooecial cross section oval with large diameter $0.14 \mathrm{~mm}$ and small diameter $0.06 \mathrm{~mm}$ on average, and with the large axis parallel to the zoarial growth direction; autozooecial apertures arranged in longitudinal rows, separated by one or two grooves, but with a rhombic pattern overall; diagonal and longitudinal separation between autozooecial apertures being $0.26 \mathrm{~mm}$ and $0.08 \mathrm{~mm}$, respectively. Autozooecial superior hemisepta short and blunt, always present in the exozone. Heterozooecia absent. Mesotheca slightly sinuous in longitudinal section, without median rods and apparently formed by one layer of laminated microstructure. Walls laminated with an average thickness of $0.017 \mathrm{~mm}$ in the endozone and $0.095 \mathrm{~mm}$ in the exozone; pustules may be present. Extrazooecial laminated skeleton also present in zoarial margins, forming longitudinal grooves.

Discussion. - This zoarium is closely related to Graptodictya meneghinii (Vinassa de Regny, 1942) as was described by Ernst \& Key (2007) from the Montagne Noire, France. The two collections share the same relative size of the large and small diameter of the zoarial branches; the angle of autozooecia with the mesotheca and the shape of the latter; the oval shape of the autozooecial apertures and its separation, both longitudinally and diagonally; the presence of hemisepta and their shape; the distribution and the microstructure of the extrazooecial skeleton, as well as the absence of heterozoecia and maculae. However, no transversal section is available and so, the shape of autozooecia in the endozone, the way they are placed with respect to the mesotheca, and the transversal shape of the mesotheca can not be analyzed. Thus, this specimen can only be referred provisionally to Graptodictya meneghinii.

Table 1. Summary of the statistical analysis of Graptodictya cf. meneghini (Vinassa de Regny, 1942) including the observed range (Or), the mean value $(\mathrm{X})$, the standard deviation (SD), the number of measurements $(\mathrm{Nm})$, and the number of zoaria from which these measurement were made (Nsp).

\begin{tabular}{|c|c|c|c|c|c|}
\hline Character & Or & $X$ & DS & $\mathrm{Nm}$ & Nsp \\
\hline Autozooecial angle with mesotheca & $30^{\circ}-55^{\circ}$ & $44^{\circ}$ & 10 & 6 & 1 \\
\hline Autozooecial angle with zoarial surface & $70^{\circ}-72^{\circ}$ & $71^{\circ}$ & 1 & 3 & 1 \\
\hline Autozooecial large diameter (in $\mathrm{mm}$ ) & $0.09-0.19$ & 0.14 & 0.04 & 10 & 1 \\
\hline Autozooecial small diameter (in mm) & $0.05-0.08$ & 0.06 & 0.01 & 10 & 1 \\
\hline Autozooecial separation in diagonal direction (in $\mathrm{mm}$ ) & $0.05-0.1$ & 0.08 & 0.02 & 6 & 1 \\
\hline Autozooecial separation in growth direction (in mm) & $0.20-0.3$ & 0.26 & 0.04 & 6 & 1 \\
\hline Autozooecial wall thickness in endozone (in mm) & $0.015-0.02$ & 0.017 & 0.003 & 6 & 1 \\
\hline Autozooecial wall thickness in exozone (in mm) & $0.080-0.115$ & 0.095 & 0.01 & 6 & 1 \\
\hline Endozone thickness (in mm) & $0.11-0.3$ & 0.2 & 0.10 & 5 & 1 \\
\hline Exozone thickness (in mm) & $0.15-0.2$ & 0.18 & 0.02 & 4 & 1 \\
\hline Zoarial small diameter (in mm) & $0.60-0.7$ & 0.64 & 0.05 & 4 & 1 \\
\hline
\end{tabular}



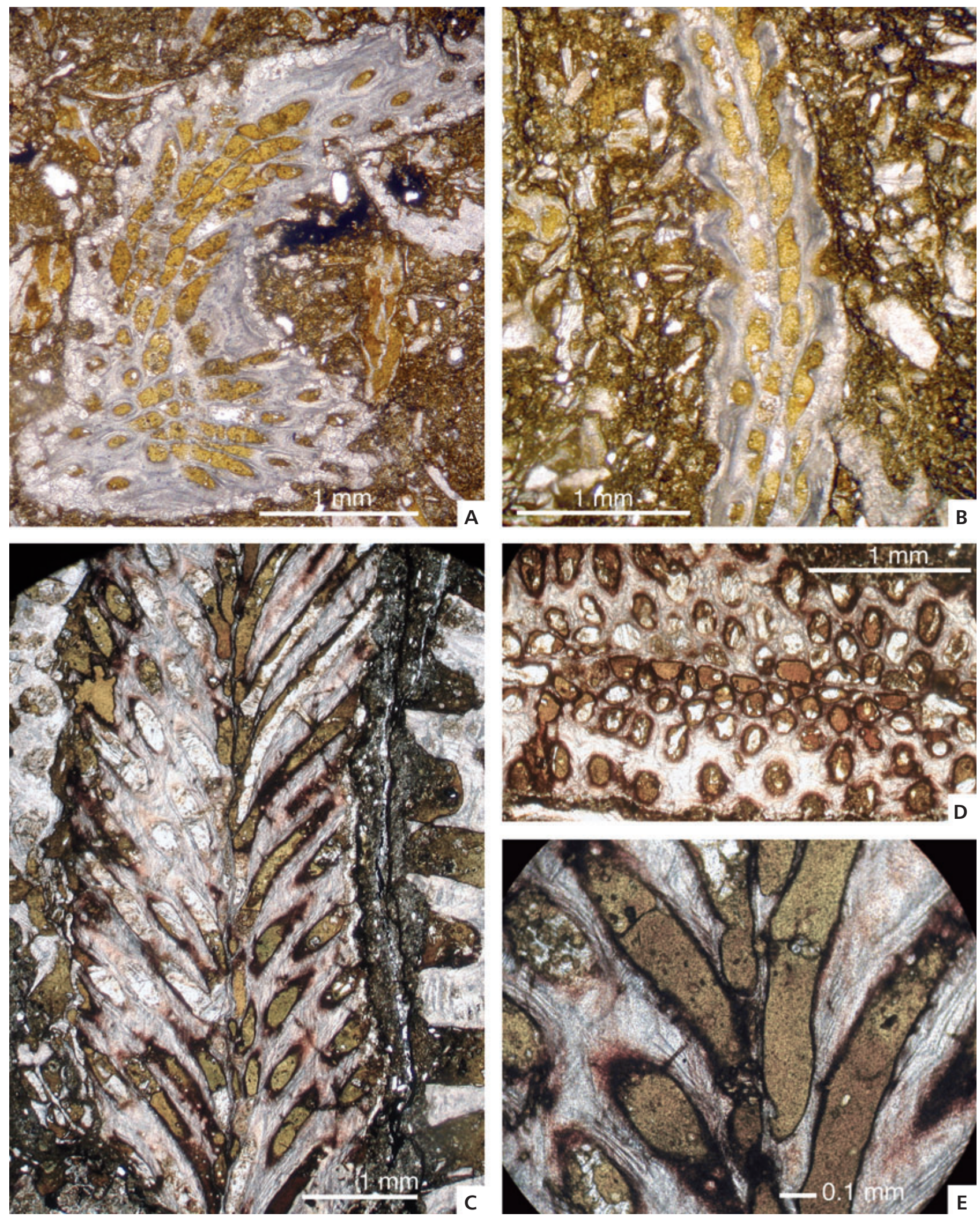

Figure 3. A, B - Graptodictya cf. meneghinii (Vinassa de Regny, 1942), MPZ 2006/189; A - oblique section; B - longitudinal section. • C-E - Amalgamoporus? sp., MPZ 2006/213; C - longitudinal section; D - transversal section; E - enlargement of the longitudinal section in C. All taxa from the La Peña Member, in the Valdelaparra section (Fombuena, Zaragoza). 


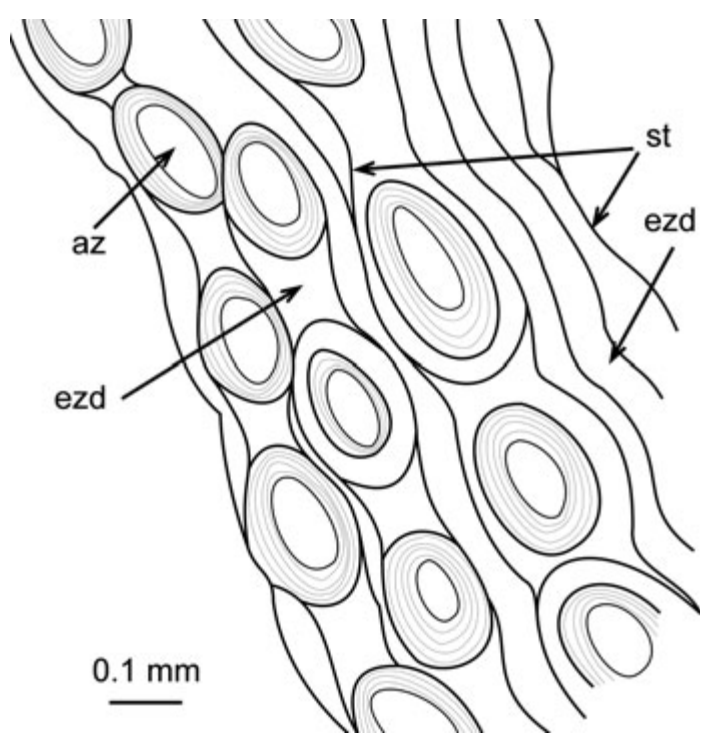

Figure 4. Graptodictya cf. meneghinii (Vinassa de Regny, 1942). Schematic tangential section showing oval autozooecial apertures (az), and thick extrazooecial laminated deposits (ezd) with longitudinal striae (st).

Occurrence. - The La Peña Member (layer 1), in the Valdelaparra section (Fombuena, Zaragoza).

Family Rhinidictyidae Ulrich, 1893

\section{Genus Amalgamoporus Farmer, 1975}

Type species. - Amalgamoporus kecius Farmer, 1975. Tulip Creek Formation, Middle Ordovician of Oklahoma (USA).

\section{Amalgamoporus? sp.}

Figures 3C-E, 6, 7, Table 2

Material. - One zoarium (MPZ 2006/213) in longitudinal and transversal sections.

Description. - Zoarium branching and bifoliated, with small diameter $1.95 \mathrm{~mm}$ on average and apparent large diameter $11 \mathrm{~mm}$. Length of autozooecia $2.1 \mathrm{~mm}$ on average, and with a constant diameter of $0.16 \mathrm{~mm}$ on average; budding from the mesotheca and forming an average angle of $20^{\circ}$ with it, but at the endozone-exozone transition autozooecia slightly bend to intersect the external surface at an angle of $41^{\circ}$ on average; autozooecia short and blunt, superior and inferior hemisepta can be present; in transversal section autozooecial subcircular to oval in the endozone and with straight contact with the mesotheca. Diaphragms present, but no more than one per autozooecia, located in the inner exozone and usually concave. Mesotheca composed of two external laminated layers and a central granular layer, all of them continuous and slightly sinuous. Median rods present in granular layer, but less than

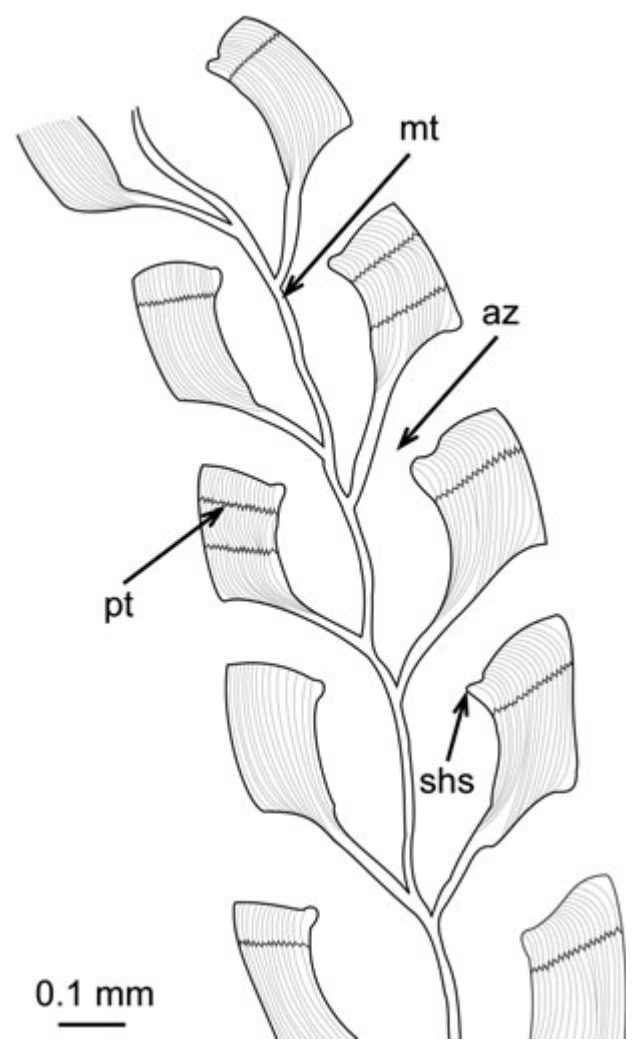

Figure 5. Graptodictya cf. meneghinii (Vinassa de Regny, 1942). Schematic longitudinal section showing autozooecia (az), superior hemisepta (shs), mesotheca (mt), and pustules (pt).

one per mm; mesotheca with an average thickness of $0.03 \mathrm{~mm}$. Autozooecial wall constituted of thick longitudinal lamina, $0.02 \mathrm{~mm}$ thick in the endozone and $0.20 \mathrm{~mm}$ thick in the exozone, on average; pustules may be present. Zoarial margins without autozooecia.

Discussion. - This zoarium shares the following features with the genus Amalgamoporus; the rounded zoarial margins without autozooecia; the longitudinal wall lamination, parallel to the autozooecial growth direction and the occurrence of pustules; the large size of the autozooecia, with occasional diaphragms and its position in the exozone; as well as the angle that the autozooecia form with the mesotheca and the zoarial surface. But this material has much fewer median rods than Amalgamoporus, as was described by Farmer (1975), and lacks the cystoidal spaces between autozooecia, characteristic of this genus. On the other hand, it was not possible to study the arrangement pattern of autozooecial apertures on the colonial surface or to check if it corresponds with that of Amalgamoporus. In spite of the similarity with Amalgamoporus as stated above, this zoarium is only provisionally referred to this genus.

Occurrence. - The La Peña Member (layer 1), in the Valdelaparra section (Fombuena, Zaragoza). 


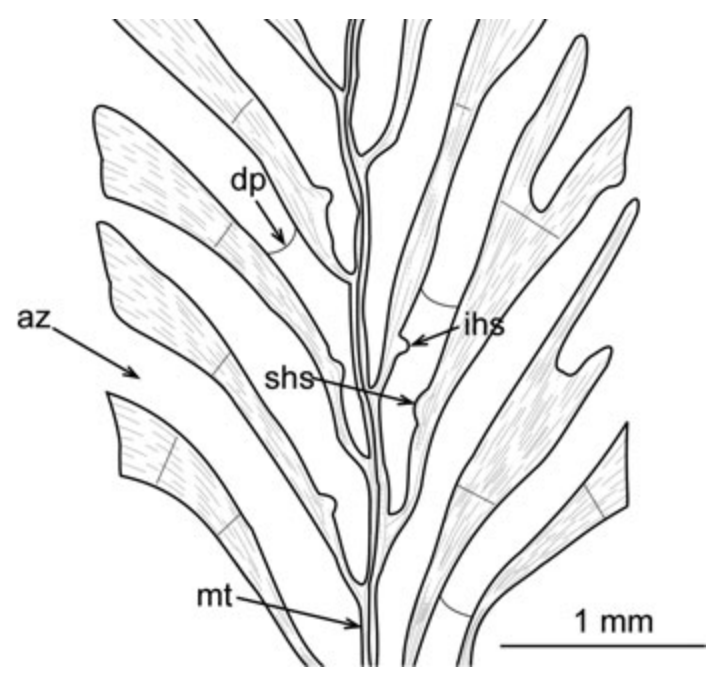

Figure 6. Amalgamoporus? sp. Schematic longitudinal section showing autozooecia (az), autozooecial diaphragms (dp), superior (shs) and inferior (ihs) hemisepta, and mesotheca (mt) composed of three layers.

Family Stictoporellidae Nickles \& Bassler, 1900

\section{Pseudostictoporella Ross, 1970}

Type species. - Pseudostictoporella typicalis Ross, 1970. Rockland Formation, Middle Ordovician of Ontario (Canada) and New York (USA).

\section{Pseudostictoporella iberiensis sp. nov.}

Figures 8A-C, 9, Table 3

2007 Pseudostictoporella iberiensis sp.; Jiménez-Sánchez et al., fig. 1 (5-7).

Holotype. - MPZ 2006/106.

Paratypes. - MPZ 2006/107 and MPZ 2006/195.

Type horizon. - La Peña Member of the Cystoid Limestone Formation, Upper Ordovician.

Type locality. - The Valdelaparra section (Fombuena, Zaragoza).

Material. - One zoarium in tangential, longitudinal and transversal sections (MPZ 2006/106) and two zoarial fragments in transversal section (MPZ 2006/107 and MPZ 2006/195).

Etymology. - After the Iberian Peninsula where the species has been described for the first time.

Diagnosis. - Pseudostictoporella characterized by superior hemisepta in autozooecia.

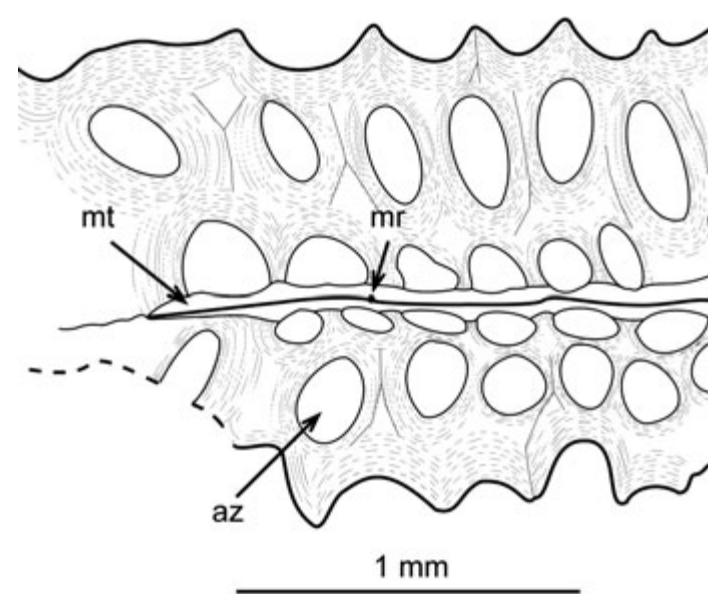

Figure 7. Amalgamoporus? sp. Schematic transversal section showing autozooecia (az) and mesotheca ( $\mathrm{mt}$ ) with median rods (mr) in central layer.

Description. - Zoaria branching and bifoliated, with large and small diameters of $2.5 \mathrm{~mm}$ and $1.1 \mathrm{~mm}$ on average, respectively. Autozooecia polygonal in shape with five or six sides and with the large axis parallel to the growth direction; apertures oval with large diameter $0.31 \mathrm{~mm}$ and small diameter $0.14 \mathrm{~mm}$ on average, and outline much smaller than the autozooecial outline; autozooecia long, about five times longer than its diameter; bedding from the mesotheca and forming an angle with it of $27^{\circ}$ on average, but at the limit of the endozone-exozone, bending and intersecting the zoarial surface at an angle of $75^{\circ}$ on average; two autozooecia per1 $\mathrm{mm}$ and 5 autozooecia per $1 \mathrm{~mm}^{2}$. Short, blunt superior hemisepta present in the exozone. Mesotheca slightly sinuous, composed of two external laminated layers and a central granular layer. Exilazooecia growing in the exozone, rhomboidal in shape with a large axis of $0.23 \mathrm{~mm}$ and small axis of $0.14 \mathrm{~mm}$ on average; one exilazooecium per $1 \mathrm{~mm}$ and 3 exilazooecia per $1 \mathrm{~mm}^{2}$. Autozooecial wall obliquely laminated, with an inverse $\mathrm{V}$ pattern in the exozone in transversal section, $0.02 \mathrm{~mm}$ thick in the endozone and $0.2 \mathrm{~mm}$ thick in the exozone on average. With an extrazooecial laminated skeleton within the exilazooecia.

Discussion. - Pseudostictoporella Ross, 1970 is a genus known only from its type species Pseudostictoporella typicalis Ross, 1970. The material described here is closely related to this species, sharing all its diagnostic characters. However, the Iberian specimens have superior hemisepta in the autozooecia and a larger angle between the autozooecia and the mesotheca $\left(27^{\circ}\right.$ in our material vs. $20^{\circ}$ in $\mathrm{Pseu}$ dostictoporella typicalis). The occurrence of the superior hemisepta is considered important enough to define it as a new species.

Occurrence. - This species is exclusively from its type horizon in layer 1 and 2 . 
Table 2. Summary of the statistical analysis of Amalgamoporus? sp. Abbreviations as in Table 1.

\begin{tabular}{|c|c|c|c|c|c|}
\hline Character & Or & $\mathrm{X}$ & DS & $\mathrm{Nm}$ & Nsp \\
\hline Autozooecial angle with mesotheca & $17^{\circ}-27^{\circ}$ & $20^{\circ}$ & 5 & 4 & 1 \\
\hline Autozooecial angle with zoarial surface & $33^{\circ}-48^{\circ}$ & $41^{\circ}$ & 4 & 10 & 1 \\
\hline Autozooecial diameter (in mm) & $0.135-0.21$ & 0.16 & 0.022 & 10 & 1 \\
\hline Autozooecial length (in mm) & $1.4-2.3$ & 2.1 & 0.4 & 6 & \\
\hline Autozooecial wall thickness in endozone (in mm) & $0.01-0.02$ & 0.02 & 0,01 & 8 & 1 \\
\hline Autozooecial wall thickness in exozone (in mm) & $0.15-0.23$ & 0.2 & 0.03 & 6 & 1 \\
\hline Endozone thickness (in mm) & $0.12-0.3$ & 0.23 & 0.07 & 5 & 1 \\
\hline Exozone thickness (in mm) & $0.51-0.63$ & 0.58 & 0.04 & 5 & 1 \\
\hline Mesotheca thickness (in mm) & $0.02-0.04$ & 0.03 & 0,01 & 12 & \\
\hline Zoarial small diameter (in mm) & $1.68-2.07$ & 1.95 & 0.14 & 7 & 1 \\
\hline
\end{tabular}

Table 3. Summary of the statistical analysis of Pseudostictoporella iberiensis sp. nov. Abbreviations as in Table 1.

\begin{tabular}{|c|c|c|c|c|c|}
\hline Character & Or & $\mathrm{X}$ & DS & $\mathrm{Nm}$ & Nsp \\
\hline Autozooecial angle with mesotheca & $20^{\circ}-33^{\circ}$ & $27^{\circ}$ & 5 & 5 & 1 \\
\hline Autozooecial angle with zoarial surface & $63^{\circ}-81^{\circ}$ & $75^{\circ}$ & 8 & 5 & 1 \\
\hline Autozooecial large diameter (in mm) & $0.24-0.36$ & 0.31 & 0.03 & 18 & 1 \\
\hline Autozooecial small diameter (in mm) & $0.09-0.18$ & 0.14 & 0.02 & 19 & 1 \\
\hline Autozooecial wall thickness in endozone (in mm) & $0.010-0.028$ & 0.018 & 0.006 & 31 & 3 \\
\hline Autozooecial wall thickness in exozone (in mm) & $0.08-0.22$ & 0.2 & 0.17 & 17 & 1 \\
\hline Endozone thickness (in mm) & $0.11-0.3$ & 0.19 & 0.04 & 32 & 3 \\
\hline Exozone thickness (in mm) & $0.22-0.5$ & 0.34 & 0.08 & 24 & 3 \\
\hline Exilazooecial large axis & $0.16-0.42$ & 0.23 & 0.08 & 8 & 1 \\
\hline Exilazooecial small axis & $0.09-0.16$ & 0.14 & 0.03 & 10 & 1 \\
\hline Mesotheca thickness (in mm) & $0.02-0.04$ & 0.03 & 0.01 & 19 & 3 \\
\hline Number of autozooecia per $1 \mathrm{~mm}$ & $0.5-3.5$ & 2 & 0.8 & 11 & 1 \\
\hline Number of autozooecia per 1 square mm & $3-6$ & 5 & 1 & 3 & 1 \\
\hline Number of exilazooecia per $1 \mathrm{~mm}$ & $0-3$ & 1 & 1 & 11 & 1 \\
\hline Number of exilazooecia per 1 square $\mathrm{mm}$ & $2-4$ & 3 & 1 & 3 & 1 \\
\hline Zoarial large diameter (in mm) & $2.3-3.1$ & 2.5 & 0.3 & 5 & 3 \\
\hline Zoarial small diameter (in mm) & $0.9-1.5$ & 1.1 & 0.3 & 7 & 3 \\
\hline
\end{tabular}

Family indet.

\section{Prophyllodictya Gorjunova in Gorjunova \& Lavrentjeva, 1987}

Type species. - Prophyllodictya intermedia Gorjunova in Gorjunova \& Lavrentjeva, 1987. Volkhov and Kunda horizons, Middle Ordovician of Estonia and Saint Petersburg area.

Discussion. - Gorjunova (Gorjunova \& Lavrentjeva, 1987) described the ptilodictyine genus Prophyllodictya and included it in the family Rhinidictyidae. Jiménez-Sánchez et al. (in press) cladistically analyzed this family, concluding that Prophyllodictya cannot be included within the Rhinidictyidae because it does not possess the two synapomorphies that characterize this family: presence of median rods in the mesotheca and presence of cystopores (or vesicular tissue) in the zooecia. Prophyllodictya does not have any apomorphic character among those considered by Jiménez-Sánchez et al. (in press) which could allow it to be included in any other known ptilodictyine family. So they consider this genus to be within a group of genera with an uncertain family relationship. This criterion is followed here. 

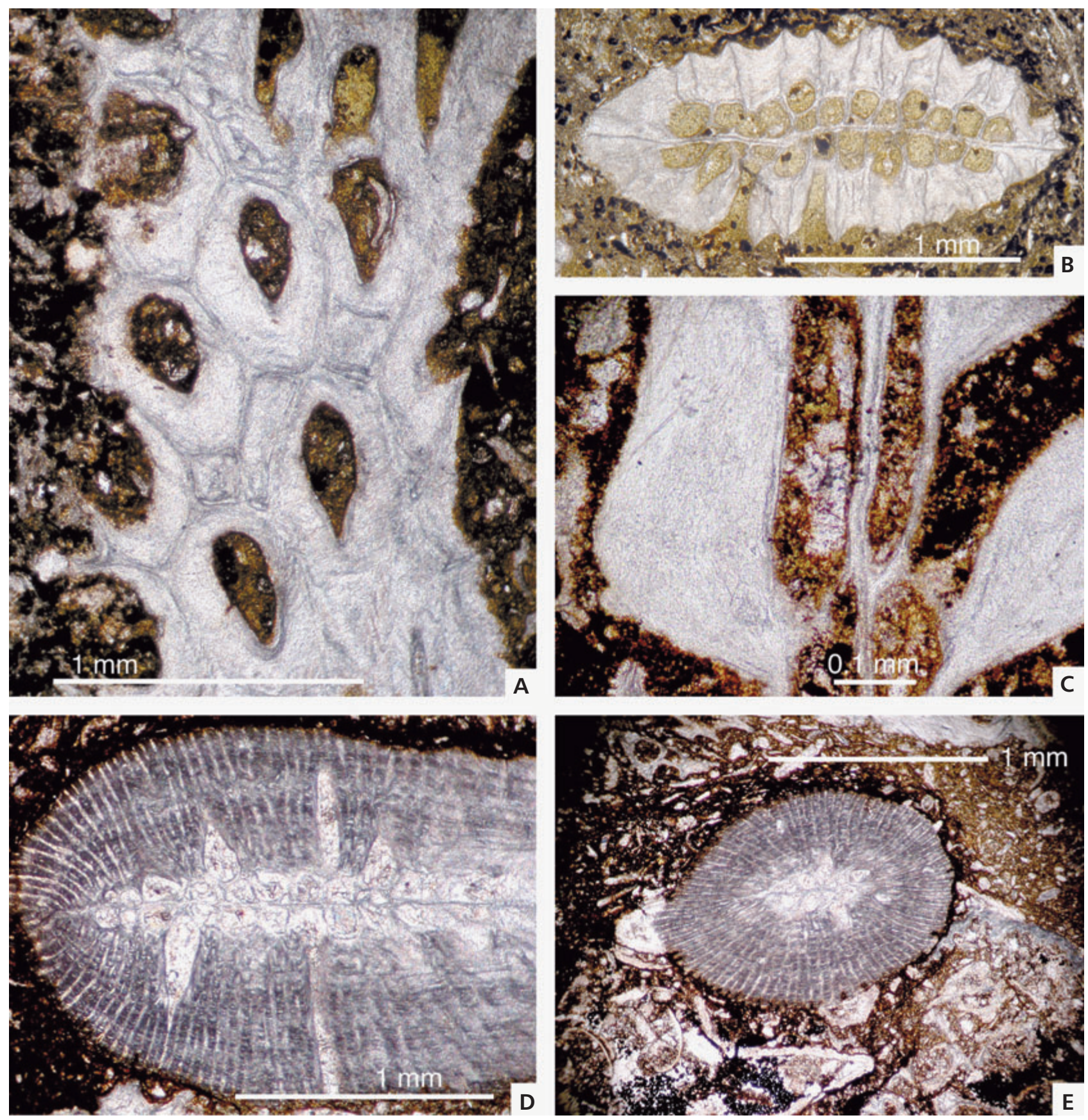

Figure 8. A-C - Pseudostictoporella iberiensis sp. nov. A, C - MPZ 2006/106 (holotype), A - tangential section, C - detail of longitudinal section. B - MPZ 2006/107, transversal section. • D, E - Prophyllodictya javieri sp. nov. D, MPZ 2006/114, transversal section in proximal zoarial zone; E, MPZ 2006/117 (holotype), transversal section. A-C from the La Peña Member in the Valdelaparra section, D and E from the La Peña Member in the La Peña del Tormo section (Fombuena, Zaragoza).

Prophyllodictya javieri sp. nov.

Figures 8D, E, 10A, B, 11, Table 4

2007 Phaenopora sp.; Jiménez-Sánchez et al., fig. 5 (3).

Holotype. - MPZ 2006/117.

Paratypes. - MPZ 2006/114-116 and MPZ 2006/118.
Type horizon. - La Peña Member of the Cystoid Limestone Formation, Upper Ordovician.

Type locality. - La Peña del Tormo Section (Fombuena, Zaragoza).

Material. - One zoarium in tangential, longitudinal and transversal sections (MPZ 2006/117); one zoarium in lon- 


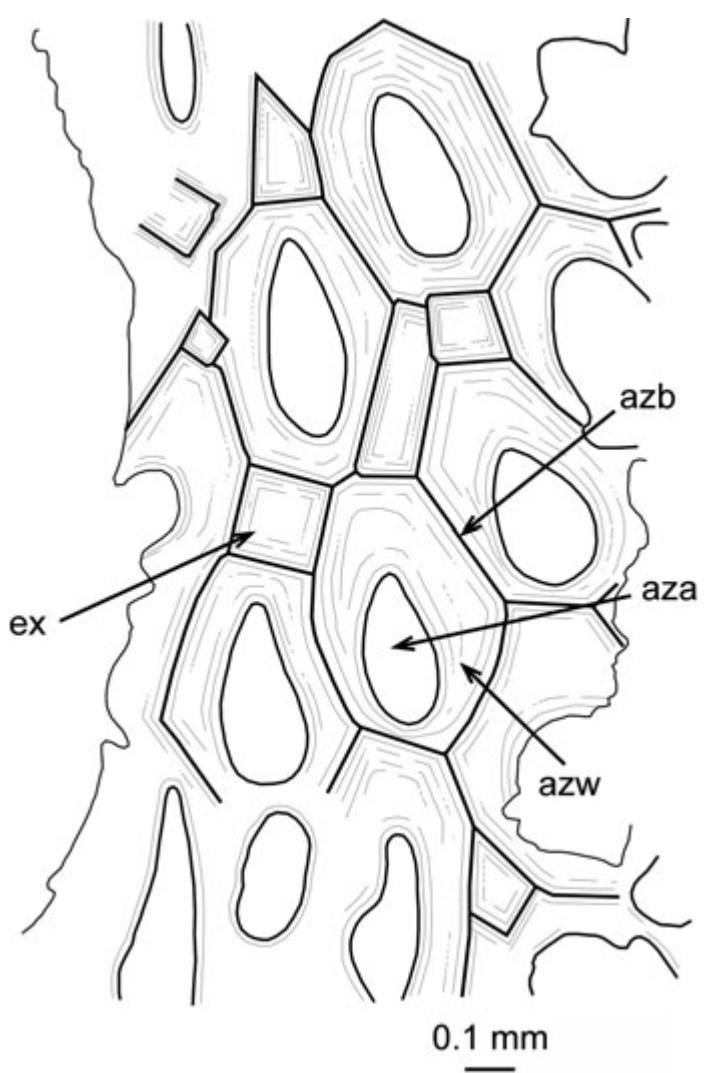

Figure 9. Pseudostictoporella iberiensis sp. nov. Schematic tangential section of the holotype (MPZ 2006/106) showing autozooecia with oval apertures (aza) and polygonal boundaries (azb), laminated autozooecial walls (azw) and exilazooecia (ex)

gitudinal and transversal sections (MPZ 2006/118); and three zoarial fragments in transversal sections (MPZ 2006/114, MPZ 2006/115 and MPZ 2006/116).

Etymology. - Named after my husband, Javier Gómez, thanking him for his academic and personal help.

Diagnosis. - Prophyllodictya characterized by the presence of superior hemisepta and by the small diameter of autozooecia and exilazooecia.

Description. - Zoaria cribrated and bifoliated, ellipsoidal in cross section with large diameter $2.30 \mathrm{~mm}$ and small diameter $1.01 \mathrm{~mm}$ on average; zoarial base rounded in cross section. Autozooecial apertures having rhombic pattern on the surface with a distance between them of $0.30 \mathrm{~mm}$ measured in the growth direction and $0.16 \mathrm{~mm}$ in a diagonal direction. Autozooecial cross section oval with large diameter $0.18 \mathrm{~mm}$ and small diameter $0.10 \mathrm{~mm}$ on average; large axis parallel to the growth direction; autozooecia long, roughly four times the small diameter; bedding from the mesotheca, forming an angle with it of $27^{\circ}$ on average, and bending at the endozone-exozone transition until reaching the zoarial surface at an average angle of $78^{\circ}$; superior hemisepta short and blunt present in almost all autozooecia. Mesotheca sinuous, formed apparently of only one granular layer, with average thickness of $0.009 \mathrm{~mm}$, but thickest at the zoarial margins. Exilazooecial apertures small, $0.014 \mathrm{~mm}$ diameter on average; budding in the exozone, reaching the external surface at the same angle as the autozooecia and arranged in longitudinal rows between autozooecia. Autozooecial wall wavy, laminated with an average thickness of $0.008 \mathrm{~mm}$ in the endozone and $0.063 \mathrm{~mm}$ in the exozone; in transversal section significant changes in the colour of the wall waves occurs in adjacent laminae. Extrazooecial laminated skeleton present in zoarial base and zoarial margins.

Discussion. - This material displays all the characters included by Gorjunova in Gorjunova \& Lavrentjeva (1987), within Prophyllodictya diagnosis, excluding the presence of superior hemisepta, a feature not considered diagnostic by Gorjunova in Gorjunova \& Lavrentjeva (1987), since neither inferior nor superior hemisepta are present in any of the five known Prophyllodictya species: Prophyllodictya gracilis (Eichwald, 1840), Prophyllodictya flabellaris (Bassler, 1911), Prophyllodictya intermedia Gorjunova, 1987, Prophyllodictya lauta Lavrentjeva, 1987, and Prophyllodictya prisca Xia, Zhang \& Wang, 2007.

The presence/absence of superior and/or inferior hemisepta in autozooecia is an important character because hemisepta modify the internal structure of autozooecia. However, it is not clear whether this character by itself is enough to define a new genus since there are polymorphic genera with respect to this character. So, the assignment of this material to Prophyllodictya is based on the remaining characters shared with this genus. In this case, the presence of superior hemisepta should be added to Gorjunova's diagnosis in Gorjunova \& Lavrentjeva (1987).

The new species, Prophyllodictya javieri, is similar to Prophyllodictya lauta Lavrentjeva in Lavrentjeva \& Gorjunova, 1987. Both species lack autozooecial diaphragms and maculae, in addition the distance between adjacent autozooecial apertures is similar.

Occurrence. - La Peña Member in la Peña del Tormo section and in the Rebollarejo Member (layer 6) in the Valdelaparra section (Fombuena, Zaragoza).

Suborder Rhabdomesina Astrova \& Morozova, 1956 Family Arthrostylidae Ulrich, 1882

\section{Glauconomella Bassler, 1952}

Type species. - Glauconome disticha Goldfuss, 1831. Upper Silurian, England. 

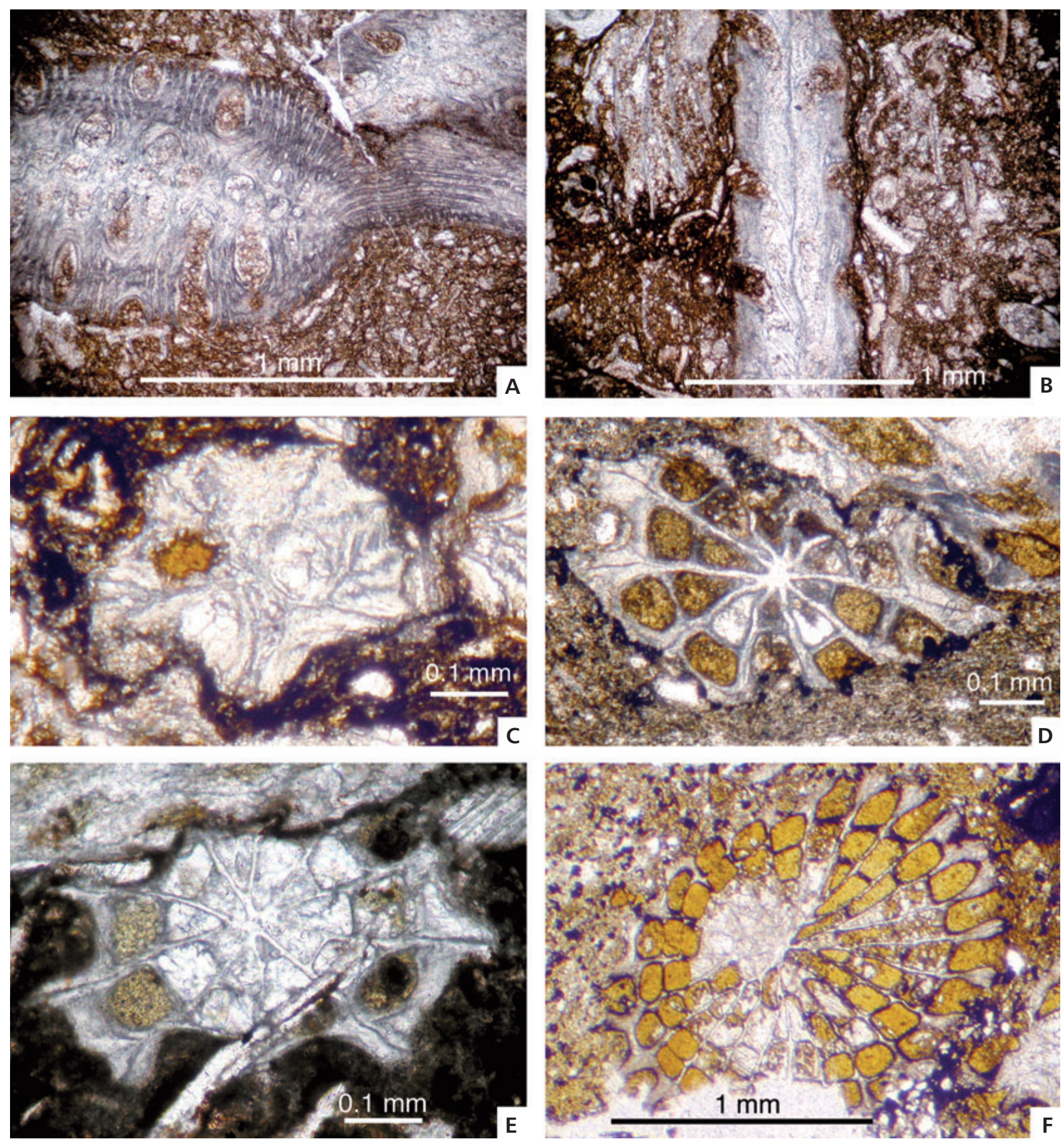

Figure 10. A, B - Prophyllodictya javieri sp. nov. A - MPZ 2006/118, oblique section; B - MPZ $2006 / 117$ (holotype), longitudinal section. - C - Glauconomella sp. MPZ 2006/127, transversal section. • D, E - Ulrichostylus radiatus Conti, 1990. D - MPZ 2006/192, transversal section; E - MPZ 2006/227, transversal section. • F - Moyerella? sp. MPZ 2006/128, transversal section. A and B from the La Peña Member in the La Peña del Tormo section, C-F from the La Peña Member in the Valdelaparra section (Fombuena, Zaragoza).

Glauconomella sp.

Figure 10C, Table 5

Material. - Two zoarial fragments in transversal section (MPZ 2006/127 and MPZ 2006/254).
Description. - Zoaria of slender, articulated branches, $0.42 \mathrm{~mm}$ average diameter; branch obverse side with autozooecial apertures distributed in four longitudinal rows and branch reverse side without apertures, but with longitudinal grooves; obverse side with a median keel and angular 


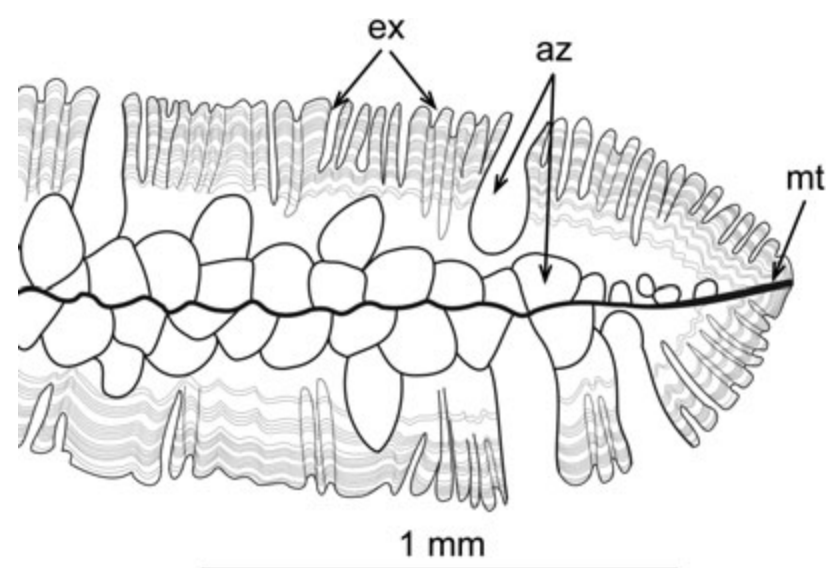

Figure 11. Prophyllodictya javieri sp. nov. Schematic transversal section of the zoarium MPZ 2006/115 showing autozooecia (az), exilazooecia (ex), and mesotheca (mt).

outline. Reverse autozooecia small and circular, front autozooecia large, $0.12 \mathrm{~mm}$ average diameter; autozooecia separated by a dark line; in the exozone, numerous dark, planar zones, similar to an autozooecial boundary, radiating from this boundary. Autozooecial wall laminated with inverse $\mathrm{V}$ pattern in the exozone and an average thickness of $0.034 \mathrm{~mm}$. Extrazooecial laminated skeleton present in the distal side.

Discussion. - This material presents all the diagnostic characters of Glauconomella, but it cannot be assigned to a concrete species until a more complete specimen is found.

Occurrence. - La Peña Member (layer 7) in the Valdelaparra section (Fombuena, Zaragoza).

\section{Ulrichostylus Bassler, 1952}

Type species. - Helopora divaricatus Ulrich, 1886. Decorah Shale, Middle Ordovician of Minneapolis (USA).

Discussion. - Blake (1983) revised the genus Ulrichostylus and reduced its number of autozooecial rows from eight or more, as was considered by Bassler (1952), to between six and eight. Conti (1990) tacitly increased that number, including in the genus a species with twelve autozooecial rows. We follow Blake's (1983) diagnosis, but accept the increase in the number of autozooecial rows introduced by Conti (1990).

\section{Ulrichostylus radiatus Conti, 1990}

Figure 10D, E, Table 6

1990 Ulricostylus radiatus sp. n.; Conti, p. 116, pl. 21, figs $7-12$.

2007 Ulrichostylus radiatus Conti, 1990. - Ernst \& Key, p. 401, pl. 15, figs $1-4$.

2007 Ultichostylus sp.; Jiménez-Sánchez, et al., fig. 8 (2).

Material. - Seventeen zoarial fragments in transversal section (MPZ 2006/192, MPZ 2006/214-229).

Description. - Zoarium articulated and delicately branched; transversal section subpolygonal, $0.54 \mathrm{~mm}$ diameter on average. Axial region formed by well-defined linear axis, with autozooecia arranged radially around it; autozooecial apertures arranged on average in 8 longitudinal rows. Autozooecial cross section oval in the exozone, with

Table 4. Summary of the statistical analysis of Prophyllodictya javieri sp. nov. Abbreviations as in Table 1.

\begin{tabular}{|c|c|c|c|c|c|}
\hline Character & Or & $\mathrm{X}$ & DS & $\mathrm{Nm}$ & Nsp \\
\hline Autozooecial angle with mesotheca & $22^{\circ}-32^{\circ}$ & 27 & 5 & 3 & 1 \\
\hline Autozooecial angle with zoarial surface & $71^{\circ}-84^{\circ}$ & $78^{\circ}$ & 7 & 3 & 1 \\
\hline Autozooecial large diameter (in mm) & $0.16-0.21$ & 0.18 & 0.19 & 13 & 2 \\
\hline Autozooecial small diameter (in mm) & $0.08-0.13$ & 0.1 & 0.017 & 13 & 2 \\
\hline Autozooecial separation in diagonal direction (in mm) & $0.1-0.23$ & 0.16 & 0.03 & 23 & 2 \\
\hline Autozooecial separation in growth direction (in $\mathrm{mm}$ ) & $0.26-0.35$ & 0.3 & 0.03 & 8 & 2 \\
\hline Autozooecial wall thickness in endozone (in mm) & $0.005-0.015$ & 0.008 & 0.003 & 22 & 5 \\
\hline Autozooecial wall thickness in exozone (in mm) & $0.04-0.1$ & 0.063 & 0.02 & 15 & 5 \\
\hline Endozone thickness (in mm) & $0.19-0.35$ & 0.25 & 0.05 & 16 & 5 \\
\hline Exozone thickness (in mm) & $0.21-0.44$ & 0.35 & 0.07 & 24 & 5 \\
\hline Exilazooecia diameter (in mm) & $0.005-0.025$ & 0.014 & 0.004 & 38 & 5 \\
\hline Mesotheca thickness (in mm) & $0.005-0.01$ & 0.009 & 0.003 & 16 & 5 \\
\hline Zoarial large diameter (in mm) & $1.4-2.6$ & 2.3 & 0.7 & 5 & 5 \\
\hline Zoarial small diameter (in mm) & $0.87-1.17$ & 1.01 & 0.12 & 5 & 5 \\
\hline
\end{tabular}


Table 5. Summary of the statistical analysis of Glauconomella sp. Abbreviations as in Table 1.

\begin{tabular}{lccccc}
\hline Character & Or & X & DS & Nm & Nsp \\
\hline $\begin{array}{l}\text { Autozooecial diameter } \\
\text { (in mm) }\end{array}$ & $0.10-0.15$ & 0.12 & 0.02 & 4 & 2 \\
$\begin{array}{l}\text { Autozooecial wall thickness } \\
\text { in exozone (in mm) }\end{array}$ & $0.030-0.040$ & 0.034 & 0.005 & 4 & 2 \\
Zoarial diameter (in mm) & $0.41-44$ & 0.42 & 0.02 & 2 & 2 \\
\hline
\end{tabular}

a large diameter of $0.094 \mathrm{~mm}$ and a small diameter of $0.061 \mathrm{~mm}$ on average; a dark zone marking the boundary between adjacent autozooecia. Autozooecial cross section triangular and without visible boundary in the endozone. Exozonal walls $0.028 \mathrm{~mm}$ thick on average, composed of concentrically arranged layers around the autozooecial aperture; endozonal walls $0.009 \mathrm{~mm}$ thick on average, composed of only one crystal. Dark zones bifurcated at the zoarial surface producing prominent longitudinal ridges separating apertural rows.

Discussion. - These characters have allowed the inclusion of this material in Ulrichostylus: the diameter of the transversal section and its subpolygonal shape; the radial arrangement of autozooecial rows around one well defined central axis; the presence of prominent longitudinal ridges separating these autozooecial rows; the well developed autozooecial boundaries in the exozone and its absence in the endozone; the presence of dark zones; and the absence of mesozooecia. There are neither longitudinal nor tangential sections of this material to be compared with those described by Blake (1983). However, transversal sections of the Iberian material closely conform to Ulrichostylus diagnosis, therefore it can be confidently assigned to this genus.

The absence of diaphragms and acanthostyles is characteristic of Ulrichostylus radiatus Conti, 1990, as was described in the type material from Sardinia (Italy) (Conti 1990) and by Ernst \& Key (2007) in the Montagne Noire (France), in both cases Late Ordovician in age. The absence of these characters also in the Iberian material, as well as the number of autozooecial rows and an autozooecial diameter similar to that of Ulrichostylus radiatus has allowed assigning of these specimens to this species.
Ulrichostylus radiatus is similar to Ulrichostylus castatus Lobdell, 1992, but they differ in that the former species has more autozooecial longitudinal rows (7-12 in Ulrichostylus radiatus vs. 7-8 in Ulrichostylus castatus) and a smaller autozooecial diameter $(0.06-0.13 \mathrm{~mm}$ in Ulrichostylus radiatus vs. $0.1-0.2 \mathrm{~mm}$ in Ulrichostylus castatus).

Occurrence. - Maciurru and Punta S'Argiola members in the Domus-Novas Formation (Sardinia, Italy), upper Katian (Conti 1990); carbonate and clastic sequence from the Montagne Noire (France), upper Katian (Ernst \& Key 2007); Pin Formation, upper Katian, in India (Suttner \& Ernst 2007); and the La Peña Member (layers 4, 6-9, 11 and 12), in the Valdelaparra section (Fombuena, Zaragoza).

Family Hyphasmoporidae Vine, 1886

\section{Matsutrypa Gorjunova, 1985}

Type species. - Matsutrypa mera Gorjunova, 1985. Lower Silurian (Llandovery) of Estonia.

\section{Matsutrypa cf. rogeri Ernst \& Key, 2007}

Figures 12C-E, 13, Table 7

cf. 2007 Matsutrypa rogeri sp. nov.; Ernst \& Key, p. 45, pl. 15, figs 16, 17, pl. 16, figs 1-3.

2007 Matsutrypa sp.; Jiménez-Sánchez et al., fig. 5 (1 and 4).

Material. - Eighteen zoarial fragments in transversal section (MPZ 2006/125, MPZ 2006/191, MPZ 2006/235-238, MPZ 2006/240-251); two zoarial fragments in longitudinal section (MPZ 2006/233 and MPZ 2006/234); one zoarial fragment in tangential section (MPZ 2006/253); and one zoarial fragment in oblique section (MPZ 2006/230).

Description. - Zoarium with erect growth habit, with segments of different sizes; transversal section subcircular, $0.50 \mathrm{~mm}$ diameter on average; axial region formed by well-defined linear axis, sometimes substituted by a thin layer; autozooecial apertures with small peristome, arranged

Table 6. Summary of the statistical analysis of Ulrichostylus radiatus Conti, 1990. Abbreviations as in Table 1.

\begin{tabular}{lccccc}
\hline Character & Or & X & DS & Nm & Nsp \\
\hline Autozooecial large diameter (in mm) & $0.06-0.13$ & 0.094 & 0.016 & 68 & 18 \\
Autozooecial small diameter (in mm) & $0.04-0.09$ & 0.061 & 0.012 & 59 & 18 \\
Autozooecial rows number & $7-11$ & 8 & 1 & 17 & 73 \\
Autozooecial wall thickness in endozone (in mm) & $0.005-0.015$ & 0.009 & 0.002 & 18 \\
Autozooecial wall thickness in exozone (in mm) & $0.015-0.06$ & 0.028 & 0.008 & 67 & 18 \\
Zoarial diameter (in mm) & $0.36-0.82$ & 0.54 & 0.13 & 18 & 18 \\
\hline
\end{tabular}


in longitudinal rows and separated by a small ridge. Autozooecia budding from the central axis, or central layer, at an average angle of $38^{\circ}$, but suddenly bending to grow parallel to the segment growth direction; autozooecial apertures oval with large diameter $0.102 \mathrm{~mm}$ on average, and separated by a pair of small metazooecia, triangular in shape, observed only in the exozone; a well developed dark line marks the autozooecial boundaries. Autozooecial walls laminated, $0.02 \mathrm{~mm}$ thick on average in the exozone and much thinner in the endozone, but with a high degree of recrystallization preventing exact measurement. Extrazooecial laminated deposits present, separating autozooecia.

Discussion. - The main diagnostic characters of the studied zoaria that allow their assignment to Matsutrypa Gorjunova, 1985 (see emended diagnosis by Ernst \& Key 2007) are the following: erect growth habit with different sizes of segments; axial region with a lineal axis, less commonly a central layer, from which the autozooecia bud; the oval shape of the autozooecia and the triangular shape of the metazooecia; the arrangement of autozooecia in longitudinal rows on the zoarial surface; clearly visible autozooecial boundaries; the development of a thick extrazooecial skeleton, and the absence of acanthostyles.

The study of different species included in Matsutrypa shows that the characters used to distinguish them are mainly the diameter of the zoarial segments, the number of autozooecial longitudinal rows, the density of autozooecial apertures per $\mathrm{mm}$, the thickness of the extrazooecial skeleton and the presence/absence of diaphragms. The poor preservation of this material prevented measurement of autozooecia density. Nevertheless, in most of the other features, the Iberian material is similar to Matsutrypa rogeri Ernst \& Key, 2007 (upper Katian of the Montagne Noire) with the exception that Ernst \& Key (2007) described occasional diaphragms in the autozooecia, not observed in the Iberian material. Therefore, these specimens are only provisionally assigned to Matsutrypa rogeri.

Specimens MPZ 2006/235-238, 240-243, 245, 247, 249,250 , all in transversal section, have some characteristics different from those in the remaining specimens. They have a smaller zoarial and autozooecial diameter, thinner autozooecial walls, and only in one section a pair of metazooecia between autozooecia can be seen. In spite of these differences these specimens have also been included in the same taxon refered here to as Matsutrypa rogeri, because they seem to be secondary segments. The fact that most sections lack the pair of metazooecia could be a consequence of the orientation of the thin section. Metazooecia are very small structures and they are longitudinally separated, therefore they are difficult to see in randomly cut thin sections.

Occurrence. - La Peña Member (layers 1, 7 and 10), in the Valdelaparra section (Fombuena, Zaragoza).
Table 7. Summary of the statistical analysis of Matsutrypa cf. rogeri Ernst \& Key, 2007. Abbreviations as in Table 1.

\begin{tabular}{lccccc}
\hline Character & Or & X & DS & Nm & Nsp \\
\hline $\begin{array}{l}\text { Autozooecial angle respect } \\
\text { central axis }\end{array}$ & $19^{\circ}-51^{\circ}$ & $38^{\circ}$ & 11 & 10 & 3 \\
$\begin{array}{l}\text { Autozooecial large diameter } \\
\text { (in mm) }\end{array}$ & $0.01-0.04$ & 0.02 & 0.01 & 39 & 15 \\
$\begin{array}{l}\text { Autozooecial wall thickness } \\
\text { in exozone (in mm) }\end{array}$ & $0.01-0.04$ & 0.02 & 0.01 & 39 & 15 \\
\begin{tabular}{l} 
Zoarial diameter (in mm) \\
\hline
\end{tabular} & $0.33-0.84$ & 0.50 & 0.13 & 19 & 19 \\
\hline
\end{tabular}

Family Nematotrypidae Spjeldnaes, 1984

\section{Genus Moyerella Nekhoroshev, 1956}

Type species. - Meyerella stellata Nekhoroshev, 1956. Lower Silurian (Llandovery) of Russia.

\section{Moyerella? sp.}

Figures 10F, 12A, B, 14-21, Tables 8, 9

Material. - Twenty zoarial fragments in transversal section (MPZ 2006/128, MPZ 2006/143-145, MPZ 2006/147-162); and one zoarial fragment in oblique section (MPZ 2006/146).

Description. - Zoaria with erect growth habit, with circular cross section, $0.93 \mathrm{~mm}$ diameter on average. Axial region formed by well-defined axis, with two types of autozooecia: the most numerous (type 1) directly radiating from the central axis, and the other (type 2) developed between the former. Autozooecial apertures circular with an average diameter of $0.10 \mathrm{~mm}$ and laminated cingulum, $0.04 \mathrm{~mm}$ thick; autozooecial apertures laterally separated $0.15 \mathrm{~mm}$ on average, and arranged on average in 16 longitudinal rows, with a dark layer separating each row. Autozooecial

Table 8. Summary of the statistical analysis of Moyerella? sp. Abbreviations as in Table 1.

\begin{tabular}{lccccc}
\hline Character & Or & X & DS & Nm & Nsp \\
\hline $\begin{array}{l}\text { Autozooecial aperture } \\
\text { separation (in mm) }\end{array}$ & $0.11-0.23$ & 0.15 & 0.04 & 8 & 1 \\
$\begin{array}{l}\text { Autozooecial diameter } \\
\text { (in mm) }\end{array}$ & $0.08-0.14$ & 0.10 & 0.02 & 1 & 1 \\
Autozooecial rows number & $13-25$ & 16 & 3 & 21 & 21 \\
$\begin{array}{l}\text { Autozooecial wall thickness } \\
\text { in endozone (in mm) }\end{array}$ & $0.005-0.015$ & 0.009 & 0.003 & 89 & 21 \\
$\begin{array}{l}\text { Autozooecial wall thickness } \\
\text { in exozone (in mm) }\end{array}$ & $0.01-0.06$ & 0.03 & 0.01 & 135 & 21 \\
Cingulum thickness (in mm) & $0.03-0.07$ & 0.04 & 0.01 & 11 & 1 \\
Zoarial diameter (in mm) & $0.59-1.41$ & 0.93 & 0.31 & 21 & 21 \\
\hline
\end{tabular}



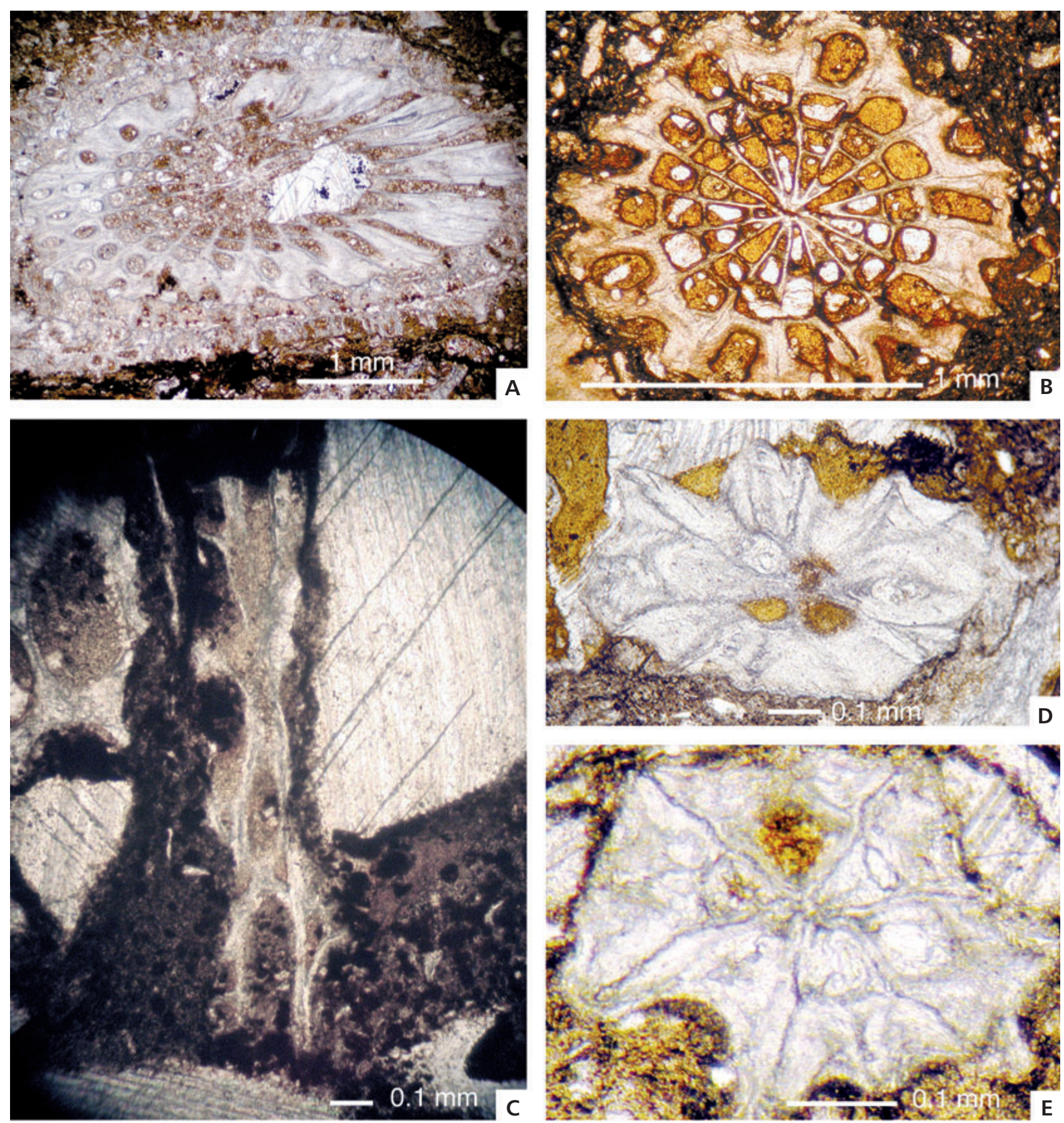

Figure 12. A, B - Moyerella? sp. A - MPZ 2006/146, transversal section; B - MPZ 2006/144, transversal section. • C-E - Matsutrypa cf. rogeri Ernst \& Key, 2007. C - MPZ 2006/253, tangential section; D - MPZ 2006/125, transversal section; E- MPZ 2006/191, transversal section. A from the La Peña Member in the La Peña del Tormo section, B-E from the La Peña Member in the Valdelaparra section.

cross section triangular in the endozone. Autozooecial walls laminated, with an inverse $\mathrm{V}$ pattern, $0.030 \mathrm{~mm}$ thick in the exozone; in the endozone autozooecial walls composed of a single crystal $0.009 \mathrm{~mm}$ thick.

Discussion. - According to Ernst \& Carrera (2007), these taxa are closer to Moyerella Nekhoroshev, 1956, sharing with it the zoarial growth habit, the axial region in the zoarium composed of a well defined central axis, the shape of autozooecia in the endozone and the exozone, and the arrangement of autozooecia in longitudinal rows. But neither heterozooecia nor acanthostyles can be seen in the Iberian material. Nevertheless, neither tangential nor longitudinal sections are available to confirm the absence of these features. 


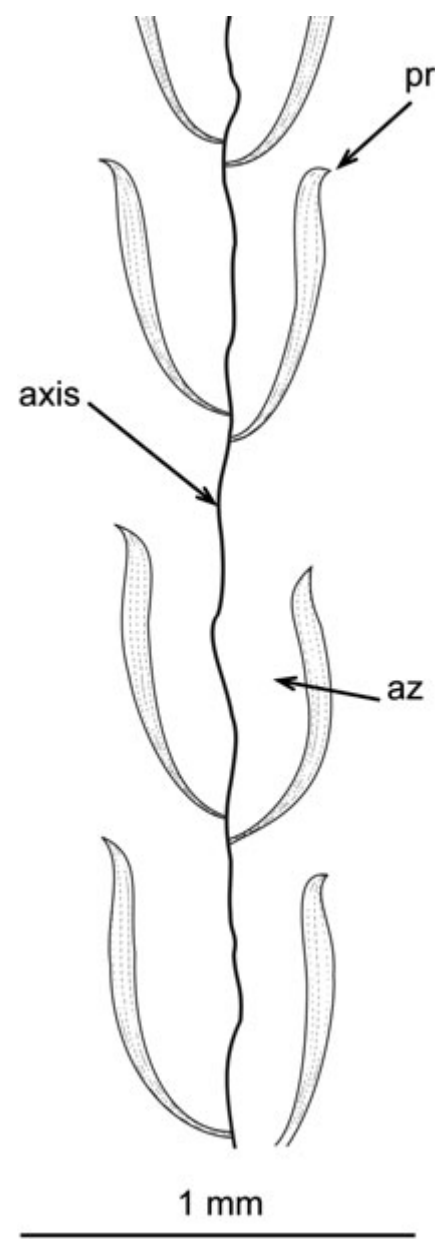

Figure 13. Matsutrypa cf. rogeri Ernst \& Key, 2007. Schematic longitudinal section of the zoarium MPZ 2006/233 showing the central axis with autozooecia (az) around it and autozooecial apertures with peristome (pr).

So, I provisionally refer this material to Moyerella while waiting for new data which can confirm this assignment.

The absence of tangential and longitudinal sections has hindered classifying this material to species level because some characters cannot be described. However, with the large number of transversal sections studied, coming from several localities and stratigraphic levels, statistical analysis to determine the degree of homogeneity of the samples and check whether all sections indeed belong to the same species have been performed. For this purpose, different univariate and multivariate analyses with PAST (Hammer et al. 2008) was carried out.

The analyzed characters are: zoarial diameter $(\mathrm{ZoD})$, number of autozooecial longitudinal rows $\left(\mathrm{N}^{\circ} \mathrm{AzR}\right)$, autozooecial diameter in the exozone $\left(\mathrm{Az}_{1} \mathrm{DEx}\right.$ for autozooecia type $1 ; \mathrm{Az}_{2} \mathrm{DEx}$ for autozooecia type 2 ), and autozooecial wall thickness in the exozone (AzWthEx).

A histogram of the number of autozooecial longitudinal rows (Fig. 15) shows the fragments can be divided into three groups: the first one is composed of the zoaria with
$12-14$ autozooecial rows (33.3\% of the sample); the second one is composed of the zoaria with 16-21 autozooecial rows $(57.14 \%)$; and the third one is composed of the zoaria with 24-25 autozooecial rows (9.5\%). All the zoaria coming from the Rebosilla Member (Luesma 2 section) are included in the first group, and more than $80 \%$ of the zoaria coming from the Rebollarejo Member (Valdelaparra section) are included in the second group; the zoaria coming from the La Peña Member (Valdelaparra and Peña del Tormo sections) are distributed among the three groups. There is no relationship between the number of autozooecial longitudinal rows and the stratigraphic position.

Considering the autozooecial wall thickness in the exozone (Fig. 16), the zoaria are also divided into three groups: the first one is composed of zoaria with a wall thickness range of $0.011-0.016 \mathrm{~mm}$ (38.1\% of the sample); the second group is composed of zoaria with wall thickness ranging from $0.018-0.021 \mathrm{~mm}(38.1 \%)$; and the third one is composed of zoaria with wall thickness ranging from $0.023-0.028 \mathrm{~mm}(23.8 \%)$. According to the provenance of zoaria, $100 \%$ of those coming from the Rebollarejo Member in the Valdelaparra section are included in the first and second groups, and $100 \%$ of the zoaria coming from the La Peña Member in the Valdelaparra and La Peña del Tormo sections are included in the third group. The zoarial fragments with thinner walls have been recorded in the upper stratigraphic member of the formation (Rebollarejo and Rebosilla members), while all zoarial fragments with thicker walls have been recorded in the basal member of the formation (La Peña Member) in the Valdelaparra and La Peña del Tormo sections.

There is no significant correlation between zoarial diameter and autozooecial wall thickness in the exozone $(r=0.3)$. But the Fig. 17 shows that most zoarial fragments with a diameter smaller than $1 \mathrm{~mm}$ have autozooecial walls of thickness less than $0.018 \mathrm{~mm}$, while those zoaria with a zoarial diameter greater than $1 \mathrm{~mm}$ have autozooecial walls of thickness greater than $0.020 \mathrm{~mm}$. However, no conclusion can be made from this analysis in connection with the stratigraphic and geographic distribution.

Nevertheless, characters $\mathrm{ZoD}$ and $\mathrm{N}^{\circ} \mathrm{AzR}$ have a good positive correlation index, with $r=0.82$ (Fig. 18), although the zoarial fragment MPZ 2006/128 plot is at some distance from the regression line. This specimen does not have an especially large diameter $(1.17 \mathrm{~mm})$, but it does have the largest number of autozooecial longitudinal rows (25 rows). Superficial erosion is not significant in this fragment, so it can be assumed that the original diameter is similar to the measured one. This anomaly could be the consequence of anomalous colonial growth, which instead of attaining a larger diameter with a proportional increase in autozooecial diameter and number of autozooecial longitudinal rows, produced an increase in size with only an increase in the number of autozooecial longitudinal rows. 
Table 9. Characters analyzed in Moyerella? sp. with the software PAST. $\mathrm{N}^{\circ} \mathrm{AzR}$ (Number of autozooecia rows), $\mathrm{Az}_{1} \mathrm{DEx}$ (Autozooecial diameter type 1 in the exozone), $A z_{2} D E x$ (Autozooecial diameter type 2 in the exozone), AzWthEx (autozooecial wall thickness in exozone), and ZoD (zoarial diameter).

\begin{tabular}{lccccc}
\hline Specimen & $\mathrm{N}^{\mathrm{o} A z R}$ & $\mathrm{Az}_{1} \mathrm{DEx}$ & $\mathrm{Az} 2 \mathrm{DEx}$ & $\mathrm{AzWthEx}$ & $\mathrm{ZoD}$ \\
\hline MPZ 2006/128 & 25 & 0.097 & 0.101 & 0.019 & 1.17 \\
MPZ 2006/143 & 13 & 0.008 & 0.085 & 0.019 & 0.63 \\
MPZ 2006/144 & 12 & 0.087 & 0.077 & 0.024 & 0.63 \\
MPZ 2006/145 & 16 & 0.115 & 0.113 & 0.025 & 1.2 \\
MPZ 2006/146 & 24 & 0.118 & 0.118 & 0.024 & 1.86 \\
MPZ 2006/147 & 14 & 0.075 & 0.067 & 0.012 & 0.65 \\
MPZ 2006/148 & 13 & 0.089 & 0.075 & 0.024 & 0.66 \\
MPZ 2006/149 & 13 & 0.074 & 0.077 & 0.018 & 0.59 \\
MPZ 2006/150 & 18 & 0.114 & 0.11 & 0.02 & 1.41 \\
MPZ 2006/151 & 17 & 0.081 & 0.076 & 0.014 & 0.84 \\
MPZ 2006/152 & 16 & 0.088 & 0.097 & 0.012 & 0.87 \\
MPZ 2006/153 & 14 & 0.090 & 0.09 & 0.012 & 0.72 \\
MPZ 2006/154 & 17 & 0.092 & 0.11 & 0.011 & 1.05 \\
MPZ 2006/155 & 13 & 0.090 & 0.09 & 0.016 & 0.75 \\
MPZ 2006/156 & 16 & 0.087 & 0.09 & 0.019 & 0.81 \\
MPZ 2006/157 & 19 & 0.114 & 0.114 & 0.016 & 0.96 \\
MPZ 2006/158 & 16 & 0.081 & 0.08 & 0.014 & 0.87 \\
MPZ 2006/159 & 16 & 0.1 & 0.1 & 0.018 & 0.87 \\
MPZ 2006/160 & 18 & 0.11 & 0.1 & 0.019 & 0.96 \\
MPZ 2006/161 & 21 & $?$ & $?$ & 0.023 & 1.2 \\
MPZ 2006/162 & 16 & 0.09 & 0.115 & 0.028 & 0.81 \\
\hline
\end{tabular}

The multivariate analyses included cluster analysis, a Principal Components analysis and a Discriminant analysis, using the characters previously mentioned. The zoarial diameter $(\mathrm{ZoD})$ has not been used for these analyses because this character is related to the other ones.

In the cluster analysis (Fig. 19), the euclidean distance and UPGMA (unweighted pair-group average, Hammer et al. 2008) algorithm have been used to define the distance between the groups. In the obtained dendrogram, the zoarial fragments are separated into two groups clearly correlated with their stratigraphic position. The first group, on the left, is composed of eight fragments mainly belonging to the La Peña Member. The second group, on the right, is composed of thirteen fragments mainly belonging to the Rebollarejo and Rebosilla Members. The fragments MPZ 206/150, MPZ 2006/157 and MPZ 2006/160 from the Rebollarejo Member are included in the first group. The study of the different characters in these zoarial fragments show that they have more autozooecial longitudinal rows and a larger autozooecial diameter than the other fragments

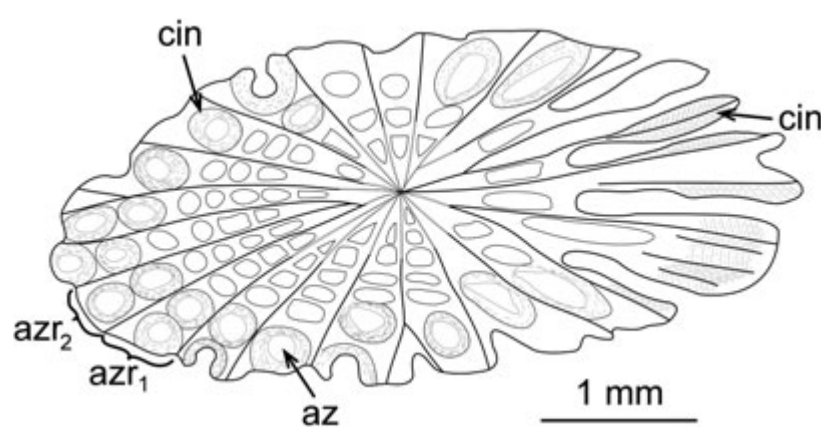

Figure 14. Moyerella? sp. Schematic oblique section of the zoarium MPZ 2006/146 showing autozooecial apertures (az) with a thick cingulum (cin), and the different types of autozooecial rows: those radiating directly from the central axis $\left(\operatorname{azr}_{1}\right)$ and those growing between the other rows $\left(\mathrm{azr}_{2}\right)$.

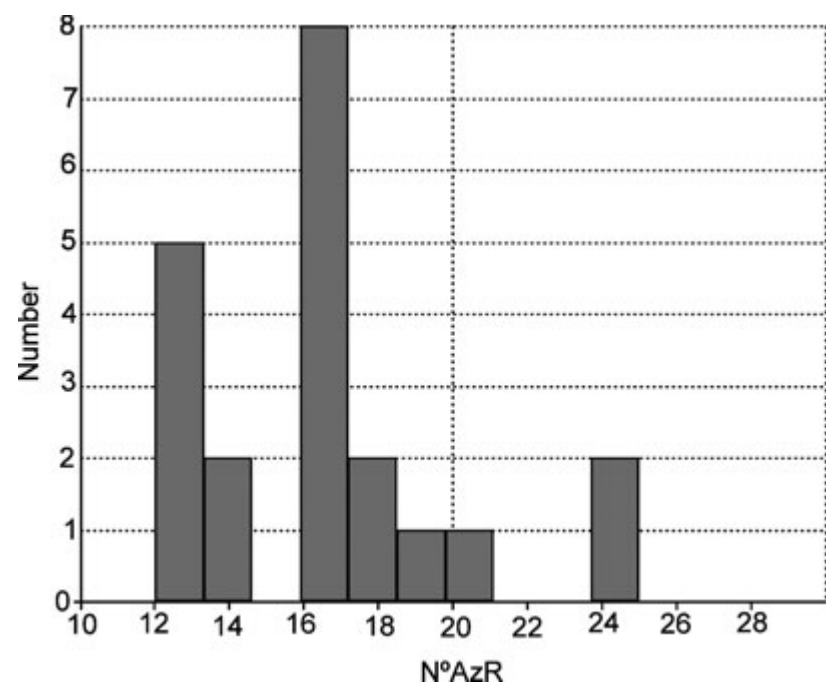

Figure 15. Histogram showing the frequency of the number of autozooecial rows in Moyerella? sp.

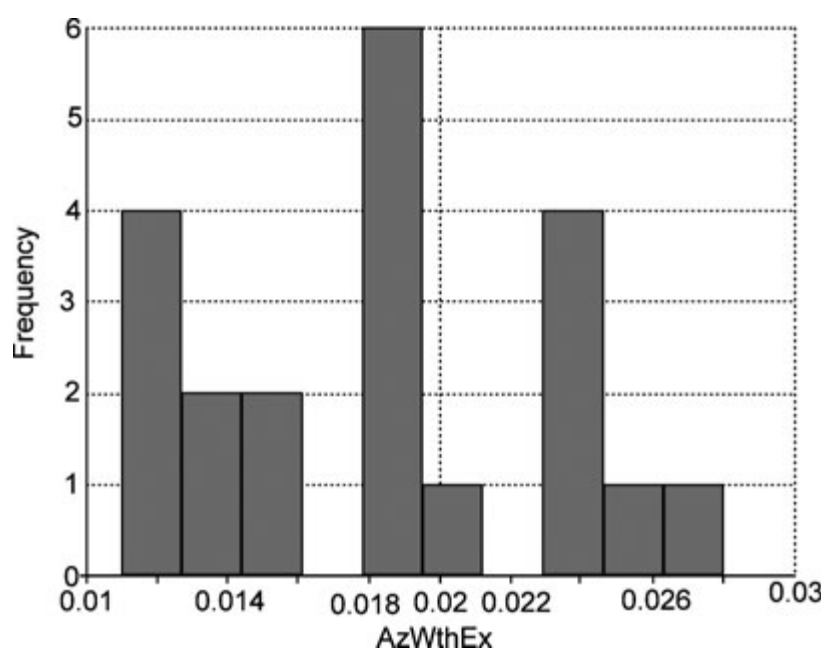

Figure 16. Histogram showing the frequency of autozooecial wall thickness in Moyerella? sp. 


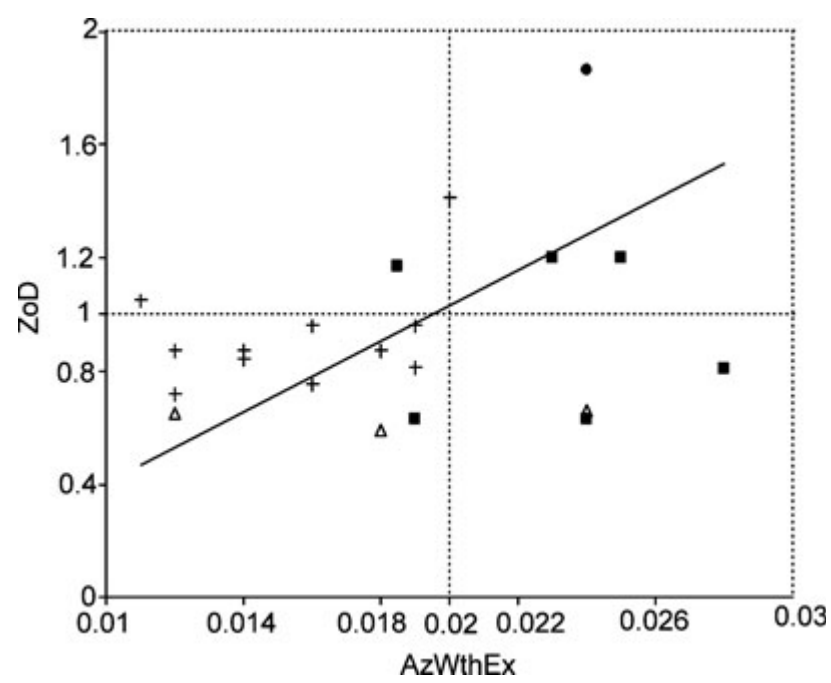

Figure 17. Autozooecial wall thickness in the exozone (AzWthEx) vs. zoarial diameter (ZoD) in Moyerella? sp. The regression line is shown, although the correlation coefficient is low $(\mathrm{r}=0.3) . \mathrm{n}$ - zoarial fragments from the La Peña Member, + - zoarial fragments from the Rebollarejo Member, both in the Valdelaparra section, I - zoarial fragments from the La Peña Member in La Peña del Tormo section, $\triangle$ - zoarial fragments from the Rebosilla Member in the Luesma 2 section.

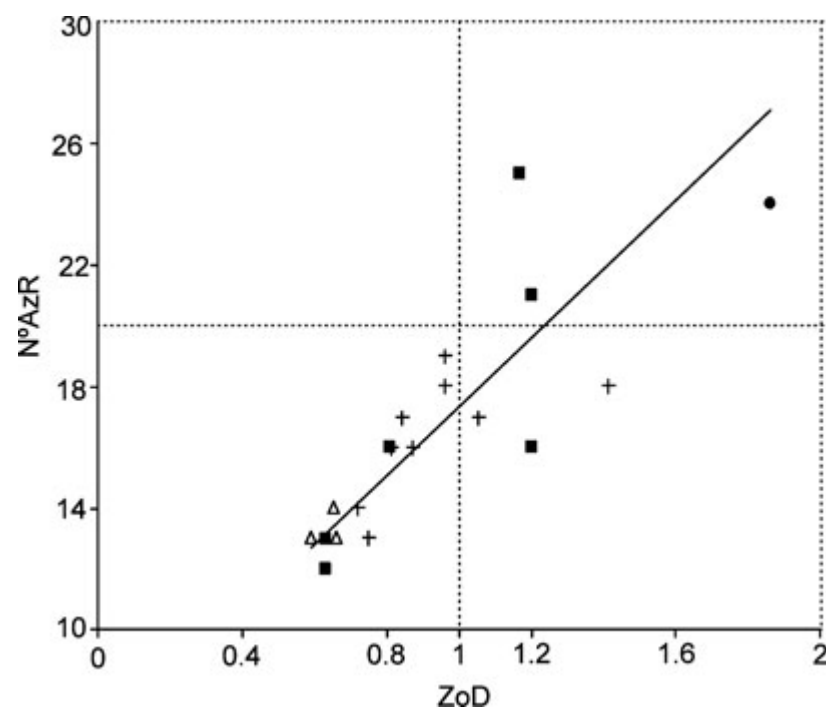

Figure 18. Zoarial diameter (ZoD) vs. number of longitudinal autozooecial rows ( $\left.\mathrm{N}^{\circ} \mathrm{AzR}\right)$ in Moyerella? sp. The regression line has a correlation coefficient (r) of 0.82. Symbols as in Fig. 17.

belonging to the Rebollarejo Member. The zoarial fragments MPZ 2006/143 and 144 come from the La Peña Member, but are included in the second group (on the right). They have fewer autozooecial longitudinal rows and a smaller autozooecial diameter than the other fragments belonging to the La Peña Member.

To see the strength of this grouping, a Principal Component analysis (Fig. 20) and a Discriminant analysis (Fig. 21) were carried out. In both analyses, the result was that the

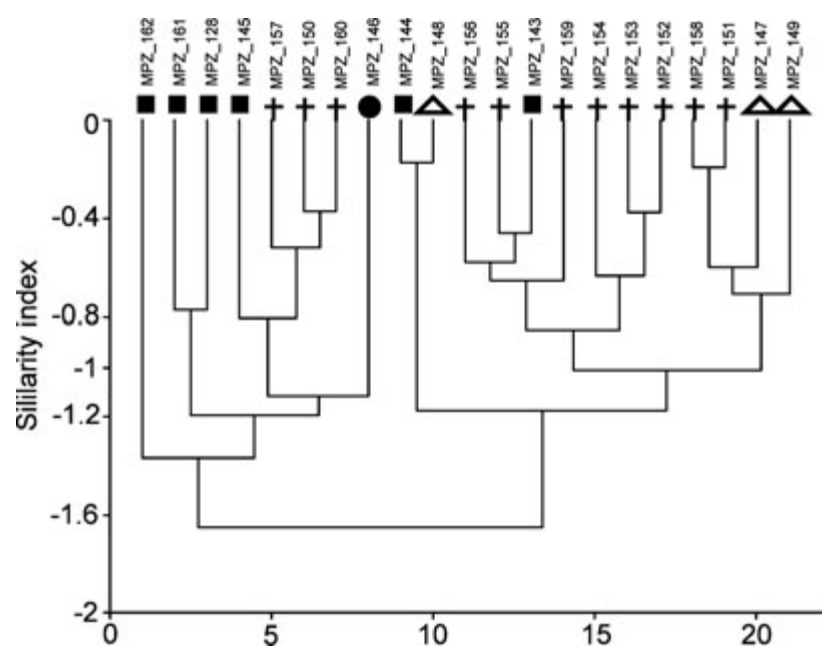

Figure 19. Dendrogram of the cluster analysis of Moyerella? sp. with the euclidean distance and UPGMA algorithm. $\mathrm{n}$ and I represent the zoarial fragments from the La Peña Member, $\boldsymbol{+}$ and $\triangle$ the zoarial fragments from the Rebollarejo and Rebosilla members, respectively.

zoarial fragments were divided into two groups, composed of the same zoarial fragments as in the dendrogram.

These analyses show that it is possible to group the zoarial fragments using the characters selected here. The first group, composed of the zoarial fragments coming from the La Peña Member, is characterized by having more autozooecial longitudinal rows, a larger autozooecial diameter, and thicker autozooecial walls than those zoarial fragments coming from the Rebollarejo and Rebosilla Members, the two stratigraphic upper members in the Cystoid Limestone Formation. So, the zoaria in the lower members are more robust than those in the upper members.

A good correlation between zoarial diameter (ZoD) and the number of autozooecial longitudinal rows $\left(\mathrm{N}^{\circ} \mathrm{AzR}\right)$, and the consequences of this correlation (increase in the autozooecial diameter with the increase in autozooecial wall thickness), suggest that all the studied fragments belong to the same species. The difference in robustness here is interpreted as an environmental adaptation. The La Peña and the Rebosilla Member represent a high energy environment near the coast, while the Rebollarejo Member represents a calm environment, further from the coast, where complex mud-mounds were developed. This difference can explain the presence of robust forms in the La Peña Member and of more delicate forms in the Rebollarejo Member. The delicate forms found in the Rebosilla Member would have come from distal, calm environments (represented by the Rebollarejo Member) and would have been transported during the storm episodes that characterize it.

Occurrence. - The La Peña Member (layer 1) in Valdelaparra and La Peña del Tormo sections, in the Rebollarejo Member (layers 4, 6, 9 and 12) in the Valdelaparra 
section (Fombuena, Zaragoza); in the Rebosilla Member (layers 22 and 23) in the Luesma 2 section (Luesma, Zaragoza).

Order Cystoporata Astrova, 1964

Suborder Ceramoporina Bassler, 1913

Family Ceramoporidae Ulrich, 1882

\section{Ceramopora Hall, 1851}

Type species. - Ceramopora imbricata Hall, 1852. Niagara Limestone Formation (Lock-port, New York), Lower Silurian of USA.

Discussion. - Utgaard (1969) made a comprehensive study of Ceramopora, emending its diagnosis; this diagnosis is followed here.

Ceramopora? lindströmi Hennig, 1908

Figures 22A-C, 23, 24, Table 10

1908 Ceramopora lidströmi n. sp.; Hennig, pp. 2-5, pl. 1, figs 1-3, pl. 4, figs 1, 2, text-figs 1-3.

2007 Ceramopora sp.; Jiménez-Sánchez et al., fig. 6 (4).

Material. - Two zoaria in tangential and longitudinal section (MPZ 2006/176 and MPZ 2006/178); and one zoarium in longitudinal section (MPZ 2006/177).

Description. - Zoaria with encrusting growth habit, composed of one or two layers with an average thickness of $0.77 \mathrm{~mm}$ per layer. Autozooecia $1.14 \mathrm{~mm}$ long, budding from thick basal layer at an angle of $40^{\circ}$ on average; this angle increases until forming an average angle of $67^{\circ}$ with the external surface. Basal layer $0.047 \mathrm{~mm}$ thick. Autozooecial cross section asymmetrically oval, with small diameter $0.29 \mathrm{~mm}$ on average and 3 autozooecia per $\mathrm{mm}$ on average. Lunaria sickle shaped and located in the autozooecium narrower side, radially arranged. Lunarial deposits $0.1 \mathrm{~mm}$ thick on average, only present in the outer exozone. Exilazooecia cross-section circular or polygonal in shape, $0.11 \mathrm{~mm}$ diameter on average and 0.8 exilazooecia per $\mathrm{mm}$. Interzooecial pores present and situated on the opposite side of the lunarium, $0.05 \mathrm{~mm}$ diameter on average. Zooecial walls $0.075 \mathrm{~mm}$ thick in the exozone and $0.03 \mathrm{~mm}$ thick in the endozone, on average, completely recrystallized. Another polymorph, wedge shaped, present in the zoarium, situated between the autozooecia and exilazooecia, but with irregular distribution; composed of thick skeletal structures, with perpendicular orientation with respect to autozooecial growth direction and circular holes between them, resembling large vesicular structures.

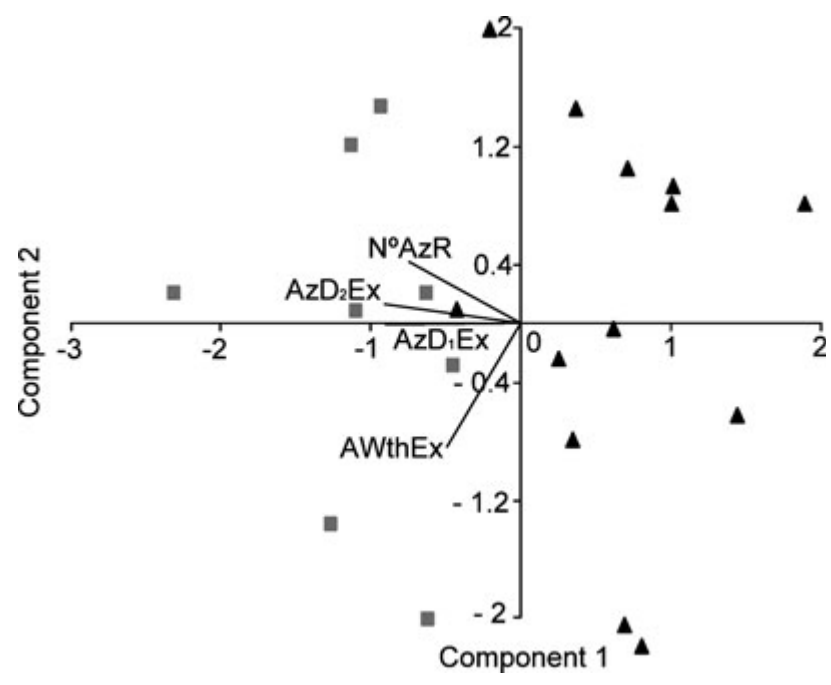

Figure 20. Principal Component Analysis of the main measurements made on Moyerella? sp. The graph shows that the separation between the first $(\mathrm{n})$ and the second $(\boldsymbol{\Delta})$ groups obtained by cluster analysis is very distinct. The character with less influence on these groups is the autozooecial wall thickness (AzWth).

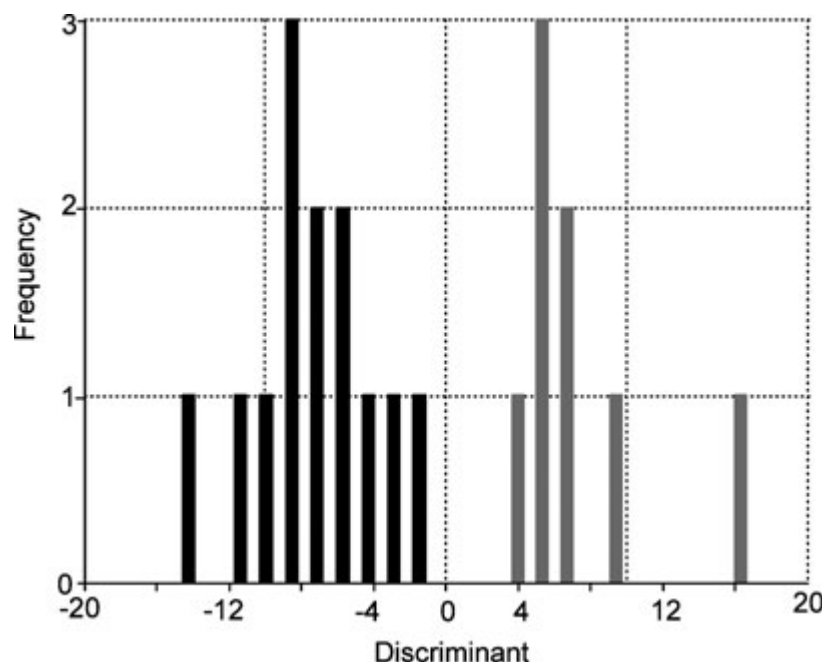

Figure 21. Discriminant analysis of the main measurements made on Moyerella? sp. The graph shows two well-differentiated groups. The group formed by gray bars corresponds to the first group in the dendrogram (on the left) and the group formed by black bars corresponds to the second one, on the right in the dendrogram.

Discussion. - The Iberian material shares several features with Ceramopora species: the growth habit; the angle at which the autozooecia bud from the epitheca and reach the zoarial external surface; the shape and arrangement of the autozooecia; the thickness of the walls in the exozone and the endozone; the presence of interzooecial pores; the shape, size and arrangement of lunaria; the absence of diaphragms and acanthostyles; as well as the presence of exilazooecia. However Utgaard (1969) in his emended diagnosis of the genus did not mention any polymorph apart 
from the exilazooecia. The material studied here has another large, wedge shaped polymorph and similar structures were described by Hennig (1908) in Ceramopora armata Hennig, 1908 and Ceramopora lindströmi Hennig, 1908 from the Lower Silurian of Sweden. This type of polymorph could be important enough to define a new genus, since it considerably changes the internal structure of the colony. Nevertheless, there are only three specimens from the Iberian Chains, and it has not been possible to describe their external surface, so Hennig's (1908) generic assignment of Ceramopora lindströmi is followed here until further study of this species can be made to clarify the situation.

The presence of the large polymorphs with vesicular structure, the budding angle of the autozooecia and its oval shape, the wall thickness and the occasional interzooecial pores are characters that the Iberian material shares with Ceramopora lindströmi, thus this material is included in this species.

Along the Mediterranean margin of Gondwana Ceramopora discoidalis (Vinassa de Regny, 1942) was previously described by Conti (1990), and Ceramopora italica (Vinassa de Regny, 1942), by Conti (1990) and Ernst \& Key (2007) from the upper Katian of the Montagne Noire and Sardinia, respectively. Ceramopora? lindströmi is similar to both species, but can be easily distinguished from them because neither Ceramopora discoidalis nor Ceramopora italica have any polymorphs apart from exilazooecia and both have more interzooecial pores. It can be also distinguished from Ceramopora discoidalis because this species has a constant wall thickness; and from Ceramopora italica because this species has larger lunarial deposits that reach the endozone.

Occurrence. - Lower Silurian of Gotland (Sweden) (Hen- nig, 1908); and in the La Peña Member (layer 1), in the Valdelaparra section (Fombuena, Zaragoza).

\section{Ceramoporella Ulrich, 1882}

Type species. - Ceramoporella distincta Ulrich, 1890. Cincinnati Group (Upper Ordovician of Cincinnati, USA).

Ceramoporella inclinata sp. nov.

Figures 22D-F, 25A, 26, 27, Table 11

2007 Ceramoporella sp.; Jiménez-Sánchez et al., fig. 6(5).

Holotype. - MPZ 2006/212.

Paratype. - MPZ 2006/179-184.

Type horizon. - La Peña Member of the Cystoid Limestone Formation, Upper Ordovician.

Type locality. - La Peña del Tormo section (Fombuena, Zaragoza).

Material. - Seven zoaria in tangential and longitudinal section (MPZ 2006/179-184 and MPZ 2006/212).

Etymology. - After the constant inclination of the autozooecia during its growth.

Diagnosis. - Ceramoporella characterized by the constant inclination of its autozooecia, by the presence of only one diaphragm per autozooecium, by its large lunaria, and by the limited number of exilazooecia.

Table 10. Summary of the statistical analysis of Ceramopora? lindströmi Hennig, 1908. Abbreviations as in Table 1.

\begin{tabular}{|c|c|c|c|c|c|}
\hline Character & Or & $\mathrm{X}$ & DS & $\mathrm{Nm}$ & Nsp \\
\hline Autozooecial angle with basal zoarial layer & $26^{\circ}-60^{\circ}$ & $40^{\circ}$ & 12 & 9 & 3 \\
\hline Autozooecial angle with superior zoarial surface & $47^{\circ}-85^{\circ}$ & $67^{\circ}$ & 11 & 9 & 3 \\
\hline Autozooecial length & $0.88-1.4$ & 1.14 & 0.21 & 9 & 3 \\
\hline Autozooecial small diameter (in mm) & $0.24-0.45$ & 0.29 & 0.05 & 33 & 2 \\
\hline Autozooecial wall thickness in endozone (in mm) & $0.015-0.045$ & 0.03 & 0.009 & 18 & 3 \\
\hline Autozooecial wall thickness in exozone (in mm) & $0.06-0.09$ & 0.075 & 0.014 & 24 & 3 \\
\hline Basal layer thickness (in mm) & $0.015-0.09$ & 0.047 & 0.018 & 24 & 3 \\
\hline Exilazooecia diameter (in mm) & $0.045-0.15$ & 0.11 & 0.038 & 20 & 2 \\
\hline Interzooecial pores diameter (in mm) & $0.03-0.08$ & 0.05 & 0.01 & 23 & 3 \\
\hline Lunaria deposit thickness (in mm) & $0.02-0,21$ & 0.1 & 0.04 & 21 & 2 \\
\hline Number of autozooecia per $1 \mathrm{~mm}$ & $2-4$ & 3 & 0.6 & 13 & 2 \\
\hline Number of exilazooecia per $1 \mathrm{~mm}$ & $0-2$ & 0.8 & 0.7 & 13 & 2 \\
\hline Zoarial layer thickness (in mm) & $0.53-0.9$ & 0.77 & 0.14 & 11 & 3 \\
\hline
\end{tabular}



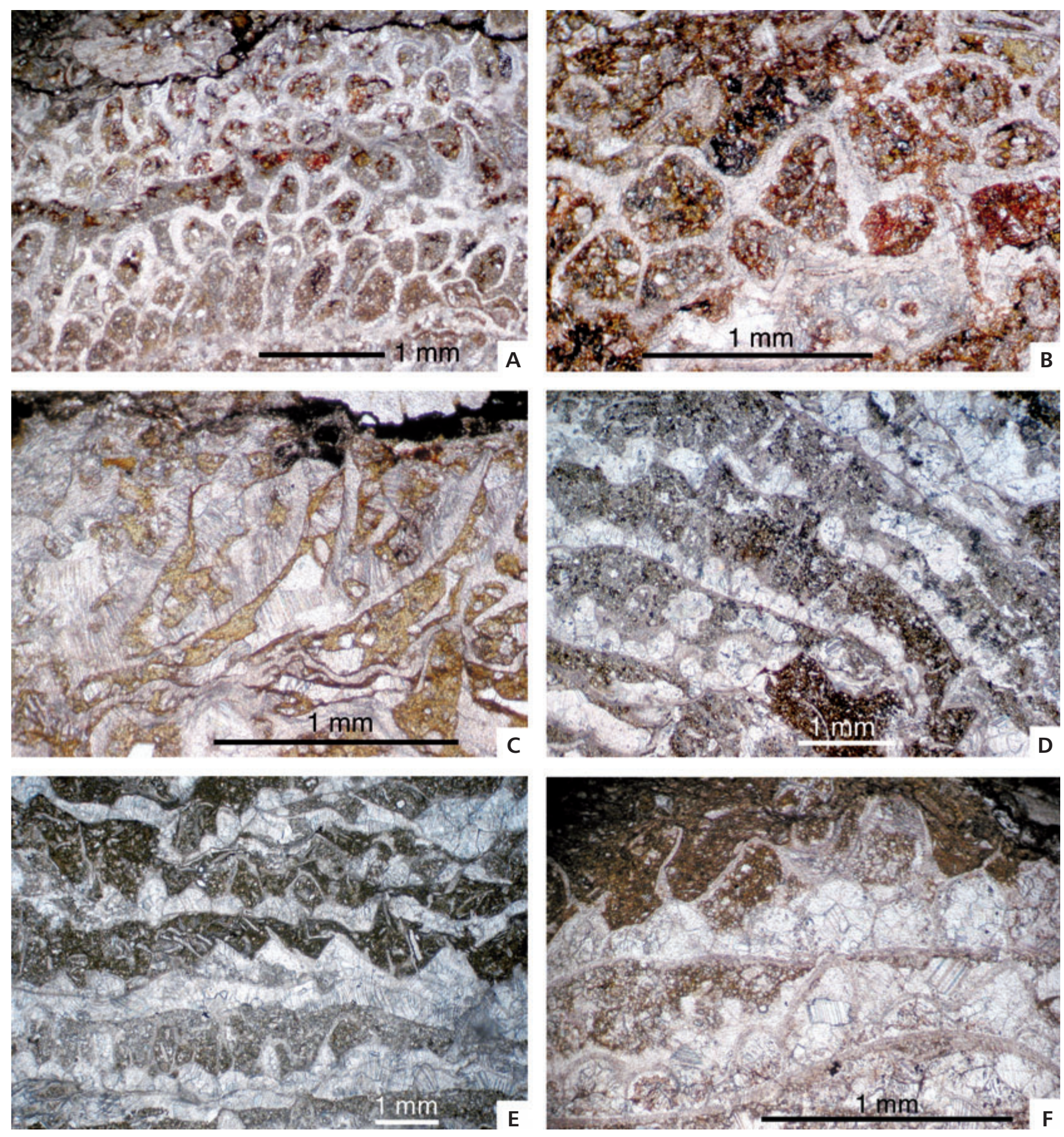

Figure 22. A-C - Ceramopora? lindströmi Hennig, 1908. A, C - MPZ 2006/178; A - tangential section; C - longitudinal section; B - MPZ 2006/176, tangential section. • D-F - Ceramoporella inclinata sp. nov. D - MPZ 2006/184; E - MPZ 2006/212 (holotype); F - MPZ 2006/180; superimposed zoarial layers, sectioned in different orientations. A-C from the La Peña Member in the Valdelaparra section, D-F from the La Peña Member in the La Peña del Tormo section.

Description. - Zoaria with encrusting growth habit composed of several layers, $0.66 \mathrm{~mm}$ thick on average. Autozooecia tubular in shape, $1.15 \mathrm{~mm}$ long on average, budding from the laminated basal layer, $0.04 \mathrm{~mm}$ thick, at a constant angle of $32^{\circ}$ on average; autozooecia adjacent to exilazooecia sigmoid in shape and with thickened basal zone. Auto- zooecial cross section asymmetrically oval, with large diameter $0.26 \mathrm{~mm}$ on average and an average of 4 autozooecia per mm. Lunaria sickle shaped and located in the autozooecium narrower side, all of them with the same orientation. Lunarial end penetrates into the autozooecial wall producing two small indentations; lunarial deposits $0.07 \mathrm{~mm}$ 


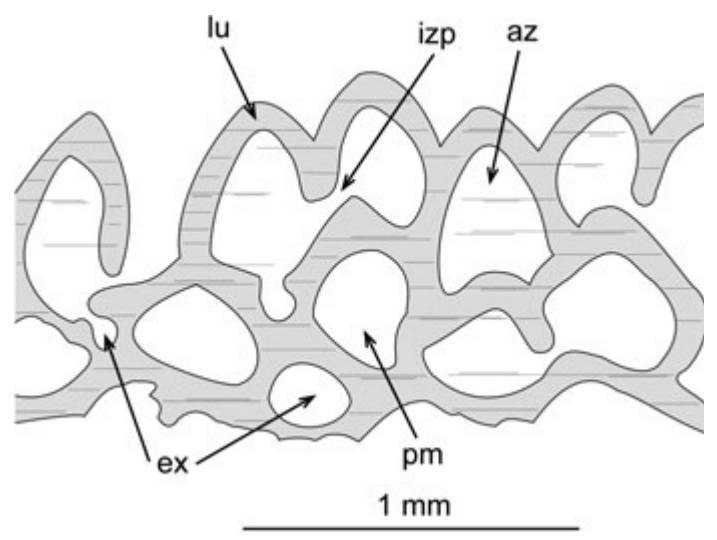

Figure 23. Ceramoporella? lindströmi Hennig, 1908. Schematic tangential section of the zoarium MPZ 2006/178 showing semioval autozooecial apertures (az) with lunaria (lu), exilazooecia (ex) and large polymorphs (pm), as well as interzooecial pores (izp).

thick on average, also present in the outer endozone, apparently being formed by single crystal. Only one diaphragm present per autozooecium, always at the same autozooecial level. Exilazooecia developed as small wedges in the inner exozone, some of them with one diaphragm; exilazooecial cross section four-sided polygonal, with average diameter of $0.15 \mathrm{~mm}$ and 0.7 exilazooecia per $\mathrm{mm}$ on average. Zooecial walls laminated with a constant thickness of $0.018 \mathrm{~mm}$ on average.

Discussion. - The characters shared between the Iberian material and the genus Ceramoporella, following Utgaard's (1968) emended diagnosis are: the encrusting growth habit; the shape of autozooecia in tangential and longitudinal section; the presence of exilazooecia growing between autozooecia from the inner exozone; the presence of only one autozooecial diaphragm and its position inside the autozooecia; the presence of only one occasional diaphragm in exilazooecia; the microstructure of the lunarial deposits,

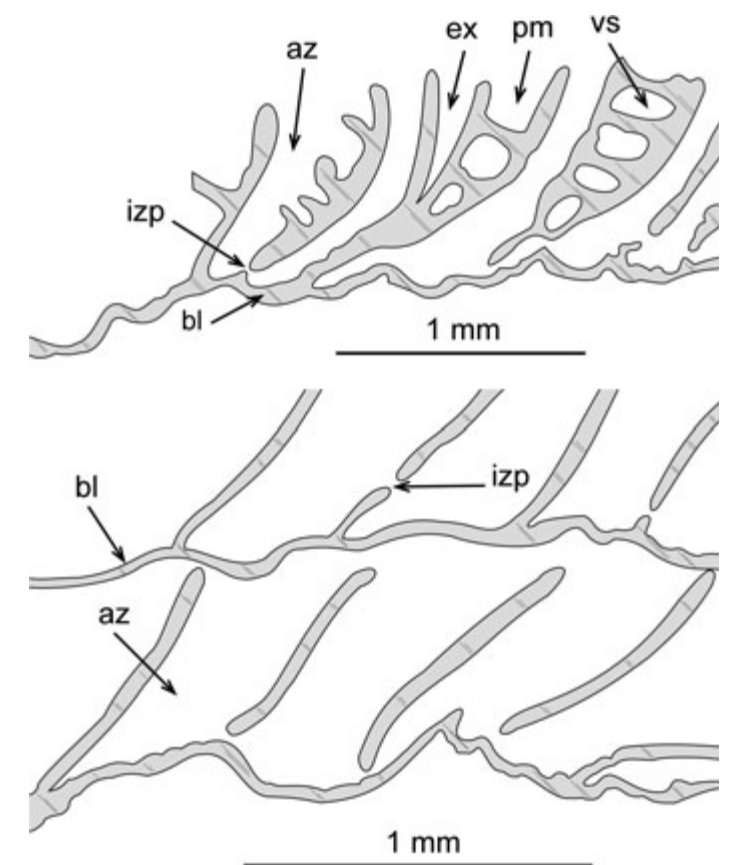

Figure 24. Ceramoporella? lindströmi Hennig, 1908. Schematic longitudinal sections of the zoaria MPZ 2006/178 (A) and MPZ 2006/176 (B), showing large polymorphs with vesicular structures (vs) and small exilazooecia (ex) in (A) and a zoarial zone without them in (B). Both figures show autozooecia (az), interzooecial pores (izp), and the basal layer (bl).

zooecial walls and epitheca; the absence of interzooecial pores; as well as the position of the lunaria sometimes indenting the autozooecial chambers. But Utgaard (1968) included in his diagnosis the presence of macula with radially arranged lunaria, and this feature was not seen in the Iberian material. In spite of this, the shared characters have enough importance to assign these specimens to Ceramoporella.

The studied zoaria have a series of diagnostic characters valid for defining them as Ceramoporella inclinata sp.

Table 11. Summary of the statistical analysis of Ceramoporella inclinata sp. nov. Abbreviations as in Table 1.

\begin{tabular}{|c|c|c|c|c|c|}
\hline Character & Or & $\mathrm{X}$ & DS & $\mathrm{Nm}$ & Nsp \\
\hline Autozooecial angle with inferior zoarial surface & $21^{\circ}-40^{\circ}$ & $32^{\circ}$ & 8 & 5 & 2 \\
\hline Autozooecial length & $0.7-1.5$ & 1.15 & 0.28 & 9 & 3 \\
\hline Autozooecial large diameter (in mm) & $0.18-0.3$ & 0.26 & 0.03 & 59 & 6 \\
\hline Autozooecial wall thickness (in mm) & $0.015-0.03$ & 0.018 & 0.007 & 24 & 6 \\
\hline Basal layer thickness (in mm) & $0.03-0.06$ & 0.04 & 0.01 & 33 & 6 \\
\hline Exilazooecia diameter (in mm) & $0.09-0.21$ & 0.15 & 0.03 & 20 & 6 \\
\hline Lunaria deposit thickness (in mm) & $0.04-0.1$ & 0.07 & 0.02 & 31 & 6 \\
\hline Number of autozooecia per $1 \mathrm{~mm}$ & $2-5$ & 4 & 1 & 16 & 5 \\
\hline Number of exilazooecia per $1 \mathrm{~mm}$ & $0-2$ & 0.7 & 0.7 & 16 & 5 \\
\hline Zoarial total height (in mm) & $4-12$ & 9.5 & 3.3 & 5 & 5 \\
\hline Zoarial layer thick (in mm) & $0.28-1.2$ & 0.66 & 0.3 & 12 & 3 \\
\hline
\end{tabular}



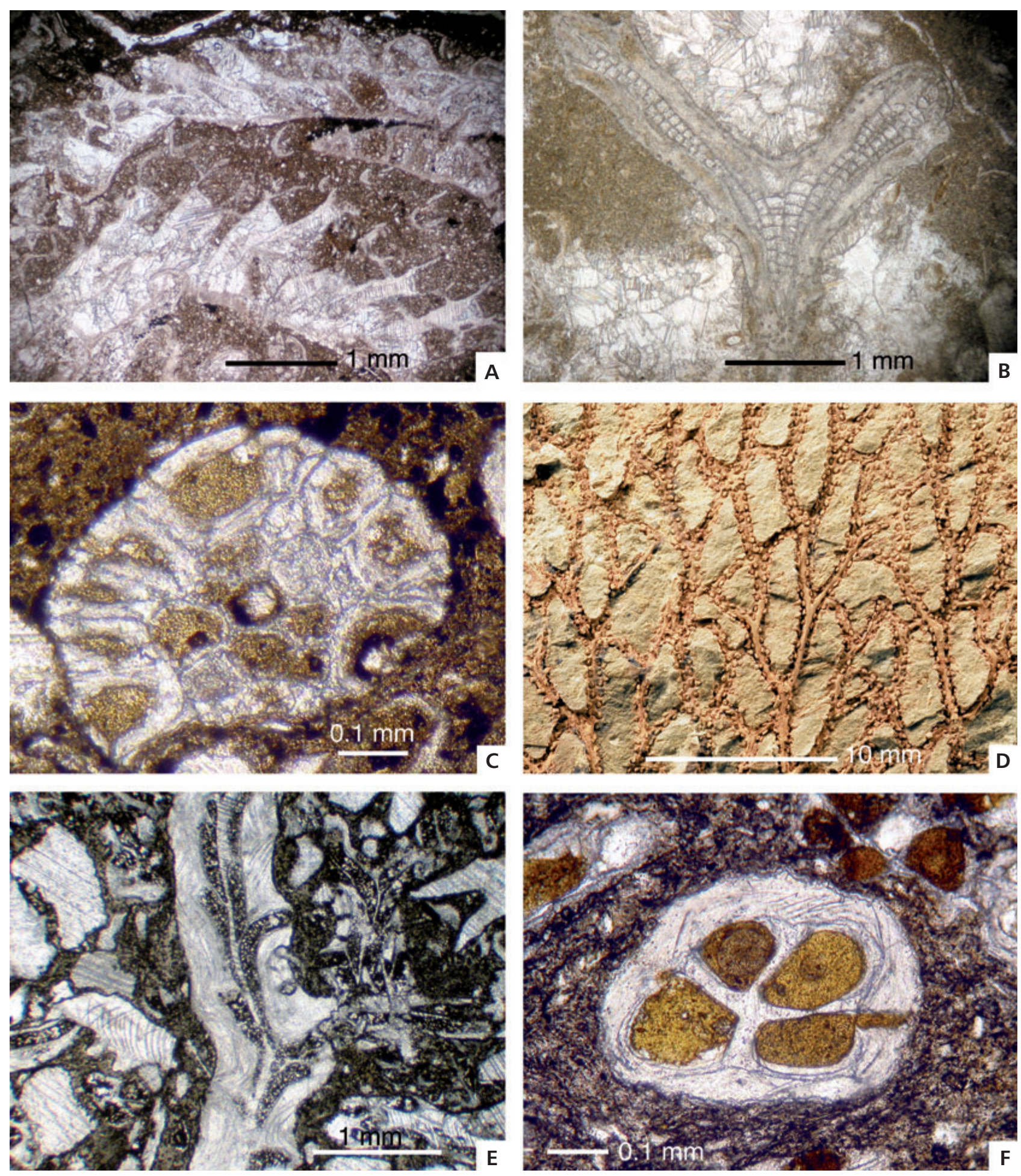

Figure 25. A - Ceramoporella inclinata sp. nov. MPZ 2006/179, longitudinal section. •B, C - Kukersella borealis (Bassler, 1911). B - MPZ 2006/193, longitudinal section; C - MPZ 2006/194, transversal section. • D-F - Chasmatopora hypnoides (Sharpe, 1853). D - MPZ 2008/196, general view of the zoarial internal mold; E - MPZ 2006/260, longitudinal section; F - MPZ 2006/186, transversal section. A from the La Peña Member in the La Peña del Tormo section, B from the Rebollarejo Member in the Valdelaparra section, C and F from the La Peña Member in the Valdelaparra section (Fombuena, Zaragoza); D from the Rebosilla Member in Luesma 3 section, and E from the Rebosilla Member in Luesma 2 section (Luesma, Zaragoza). 


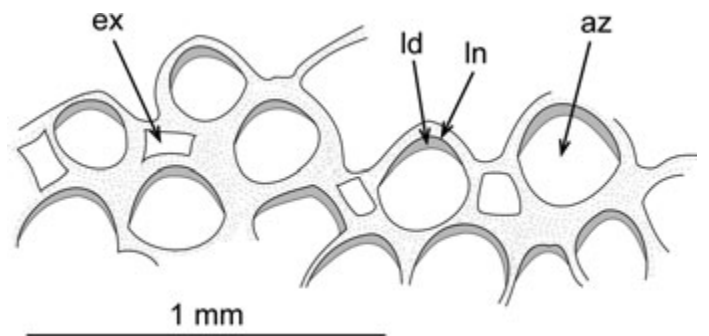

Figure 26. Ceramoporella inclinata sp. nov. Schematic tangential section of the zoarium MPZ 2006/182 showing autozooecial apertures (az) with lunaria (ln) and lunarial deposits (ld), and small exilazooecia (ex).

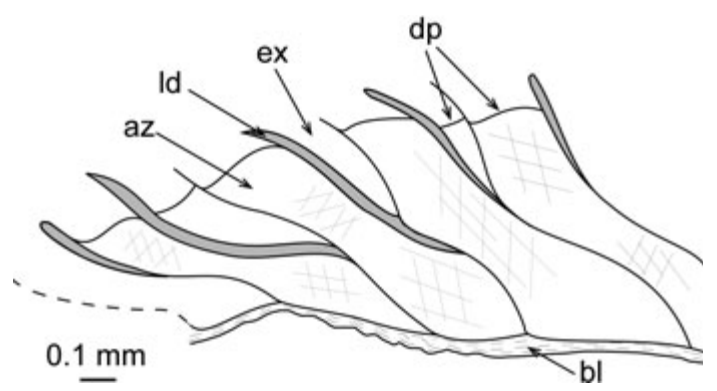

Figure 27. Ceramoporella inclinata sp. nov. Schematic longitudinal section of the zoarium MPZ 2006/179 showing autozooecia (az) and exilazooecia (ex) with a single diaphragm (dp) and the basal layer (bl).

nov. The new species is most similar to the specimens studied by Karklins (1984) from the Eden Formation (Upper Ordovician of Cincinnati), and by Buttler (1991b) in the Llanbedrog Limenstone (Upper Ordovician of Wales), included in Ceramoporella distincta Ulrich, 1890. Both species share the same general shape of the zoarium composed of a group of encrusting zooecial layers, the autozooecial wall thickness, the shape of the lunarial deposits, the absence of cores (spines) in the lunaria, and the absence of interzooecial pores. But the new species can be distinguished from Casmatoporella distincta because its autozooecia have a constant inclination, contain fewer exilazooecia and no basal diaphragm.

Along the Mediterranean margin of Gondwana Ceramoporella discoidalis Conti, 1990 [upper Katian of Sardinia (Italy), Conti (1990), and the Montagne Noire (France), Ernst \& Key (2007)] and Ceramoporella grandis Ernst \& Key, 2007, in the same Katian beds from the Montagne Noire have been previously described. Ceramoporella inclinata sp. nov. shares with both species the shape of lunarial deposits, adapted to the sinuous autozooecial walls. But it can be distinguished from both because in Ceramoporella discoidalis and Ceramoporella grandis the autozooecia reach the zoarial external surface at an angle of $90^{\circ}$, but the angle is more acute in the new species, they contain more exilazooecia, interzooecial pores are present in the autozooecial walls and cores (spines) are present in the lunaria.
Occurrence. - This species occurs exclusively in its type locality and horizon.

Order Cyclostomata Busk, 1852

Suborder Paleotubuliporina Brood, 1973

Family Crownoporidae Ross, 1967a

\section{Genus Kukersella Toots, 1952}

Type species. - Kukersella bassleri Toots, 1952. Kuckers Shales Formation (Middle Ordovician of Käva, Estonia).

Discussion. - Toots (1952) included the genus Kukersella in the family Diastoporidae (order Cyclostomata), considering significant the absence of large peristomes, mesozooecia and acanthostyles, as well as its narrow autozooecial apertures. Ross (1967a) described the new genus Crownopora, with Crownopora singularis as the type species, and the family Crownoporidae to include this genus, in addition to Diploclema Ulrich, 1889, Kukersella Toots, 1952, Mitoclema Ulrich, 1882, and Mitoclemella Bassler, 1952, which were previously included in the family Diastoporidae. Ross (1967a) included the new family in the order Cryptostomata based on the presence of vestibules. Brood (1975a) considered the external and internal structures of Crownopora and Kukersella to be identical, putting both genera as synonymous. Furthermore, Brood (1975a) proposed changing the name of the family Crownoporidae to Kukersellidae and assigning it to the order Cyclostomata. This change of order was based on the zooecial wall structure, the presence of front pseudopores and interzooecial pores, as well as the zoaria growth pattern. Buttler (1989) accepted the synonymy between the genera Kukersella and Crownopora, but she returned to Crownoporidae as the family name. Her criteria are followed here.

Kukersella borealis (Bassler, 1911)

Figures 25B, C, 28, 29, Table 12

1911 Mitoclema boreale new species; Bassler, p. 69, pl. 6, fig. 8, text-fig. 15 .

1952 Kukersella bassleri n. sp.; Toots, p. 117, pl. 7, figs 1 and 9.

1967a Crownopora singularis n. sp.; Ross, p. 645, pl. 72, figs 4-11, pl. 73, figs 1-4, pl. 74, figs $1-4$, text-fig. 4 .

1973 Crownopora singularis Ross, 1967a. - Boardman \& Cheetham, p. 145, fig. 34.

1973 Kukersella boreale (Bassler, 1911). - Brood, p. 254, fig. 2.

1974 Kukersella boreale (Bassler, 1911). - Brood, p. 425, fig. 2A. 
1975a Kukersella bassleri Toots, 1952. - Brood, p. 113, pl. 8, figs 6, 7, pl. 12, figs 1, 2.

1975b Kukersella boreale (Bassler, 1911). - Brood, p. 114, pl. 8, figs 1, 5, pl. 12, figs $1,2$.

1987 Kukersella cf. boreale (Bassler, 1911). - Hillmer \& Schallreuter, fig. $2 \mathrm{~N}$.

1987 Kukersella n. sp.; Gorjunova, pl. 4, fig. 3a-c.

1989 Kukersella borealis (Bassler, 1911). - Buttler, pp. 222-225, figs 4A-F, 5A-F, 6A, B.

1990 Kukersella borealis (Bassler, 1911). - Conti, p. 117, pl. 22, figs 7-11.

1991a Kukersella borealis (Bassler, 1911). - Buttler, pp. 104, 105, pl. 7, figs 7, 8.

1991b Kukersella borealis (Bassler, 1911). - Buttler, p. 167, fig. 20.

1996 Kukersella borealis (Bassler, 1911). - Buttler \& Massa, fig. 4h.

2007 Kukersella borealis (Bassler, 1911). - Buttler, Cherns \& Massa, p. 490, text-fig. 5D.

2007 Kukersella borealis (Bassler, 1911). - Suttner \& Ernst, p. 6, pl. 2, fig. 5.

2007 Kukersella borealis (Bassler, 1911). - Ernst \& Key, p. 365 , pl. 1, figs 3, 4, 6 .

2007 Kukersella sp.; Jiménez-Sánchez et al., fig. 8 (8, 9).

Material. - One zoarial fragment in longitudinal and transversal section (MPZ 2006/201); four zoarial fragments in longitudinal section (MPZ 2006/193, MPZ 2006/199, 200); and ten zoarial fragments in transversal section (MPZ 2006/194, MPZ 2006/203, 211).

Description. - Zoaria with branching growth habit, dichotomously bifurcated; branch transversal section circular, $0.52 \mathrm{~mm}$ diameter on average. Exozone composed of only one autozooecial ring, $0.16 \mathrm{~mm}$ thick on average. Endo-

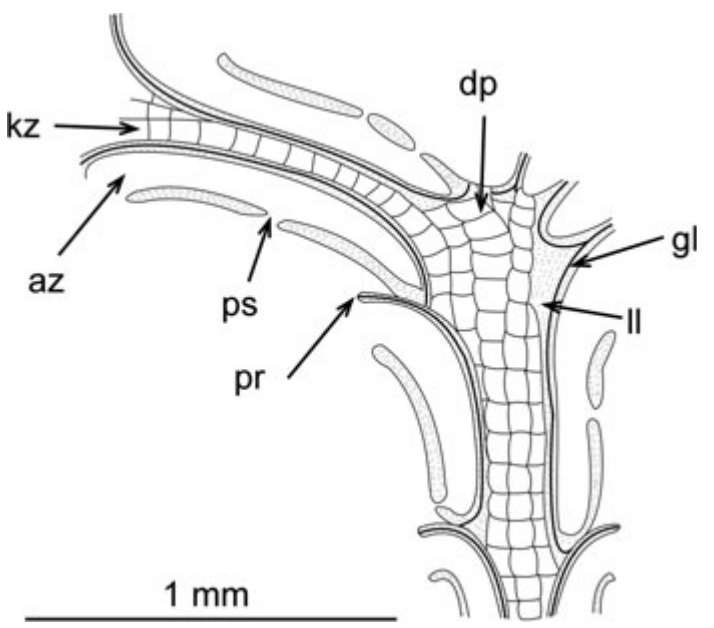

Figure 28. Kukersella borealis (Bassler, 1911). Schematic longitudinal section of the zoarium MPZ 2006/199 showing long autozooecia (az) with peristome (pr) and pseudopores (ps), kenozooecia (kz) divided by numerous diaphragms (dp), and autozooecial walls composed of two laminated layers (1l) and one granular layer (gl).

zone with $0.20 \mathrm{~mm}$ diameter on average, composed of kenozooecia, laminated skeletal material, or a hollow with neither kenozooecia nor laminated skeletal material. Autozooecia very long, developed only in the exozone; parallel to the branch growth direction, but near the external surface bending to reach it at an average angle of $36^{\circ}$; autozooecial apertures widely separated and with small peristome; autozooecial cross section subrectangular or subcircular in shape, with a chamber of average diameter $0.11 \mathrm{~mm}$; interzooecial pores, situated at the lateral-distal wall junction. Kenozooecia long and narrow, only open to the zoarial surface at the branch ends and densely tabulated by diaphragms, 13 per mm on average; without any physical continuity between kenozooecia and autozooe-

Table 12. Summary of the statistical analysis of Kukersella borealis (Bassler, 1911). Abbreviations as in Table 1.

\begin{tabular}{lcccc}
\hline Character & Or & X & DS & Nm \\
\hline Autozooecial angle with zoarial surface & $22^{\circ}-60^{\circ}$ & $36^{\circ}$ & 14 & 6 \\
Autozooecial diameter (in mm) & $0.04-0.16$ & 0.11 & 0.11 & 52 \\
Autozooecial distal wall thickness (in mm) & $0.015-0.06$ & 0.03 & 0.01 & 33 \\
Autozooecial proximal and lateral wall thickness (in mm) & $0.01-0.03$ & 0.019 & 0.004 & 63 \\
Endozone diameter (in mm) & $0.07-0.35$ & 0.2 & 0.08 & 22 \\
Exozone thickness (in mm) & $0.11-0.28$ & 0.16 & 0.03 & 68 \\
Kenozooecial diameter & $0.05-0.12$ & 0.08 & 0.02 & 12 \\
Kenozooecial wall thickness (in mm) & $0.005-0.015$ & 0.008 & 0.003 & 48 \\
Number of kenozooecia & $5-12$ & 8 & 3 & 11 \\
Number of kenozooecial diaphragm per 1 mm & $9-16$ & 13 & 3 \\
Pseudopores diameter & $0.005-0.04$ & 0.017 & 0.01 & 3 \\
Zoarial diameter (in mm) & $0.38-1.03$ & 0.52 & 0.18 & 33 \\
\hline
\end{tabular}




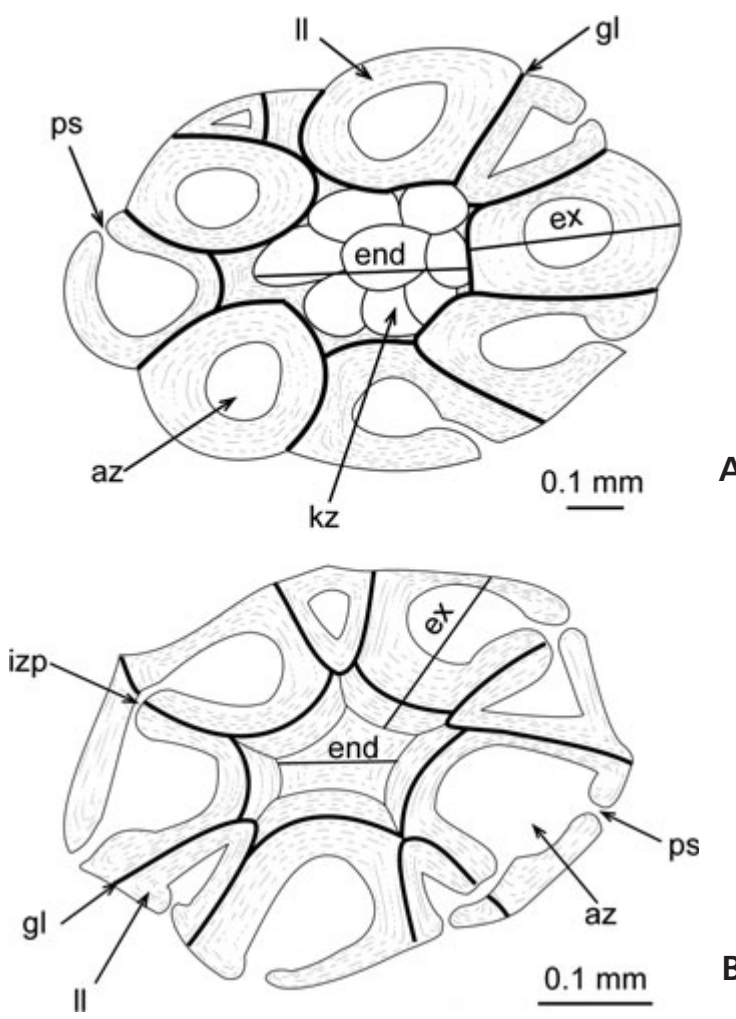

Figure 29. Kukersella borealis (Bassler, 1911). Schematic transversal sections of the zoaria MPZ 2006/201 (A) and MPZ 2006/206 (B). The two figures show autozooecia (az), pseudopores (ps), laminar (11) and granular (gl) layers in autozooecial walls and the relative size of the endozone (end) and exozone (ex). In (A) the endozone is composed of kenozooecia and in (B) it is composed of skeletal material; interzooecial pores (izp) can also be observed in (B).

cia; kenozooecial cross section subhexagonal or subcircular, $0.08 \mathrm{~mm}$ diameter on average and with 8 kenozooecia on average in the endozone, this number increases just before branch bifurcation and then reduces in the resulting branches; kenozooecia seem to be absent in the zoarial base. Autozooecial proximal and lateral walls composed of two layers, $0.019 \mathrm{~mm}$ thick on average, with a thin internal layer of granular microstructure and an external layer thickened by laminated microstructure; distal wall composed of only a thickened laminated layer, $0.030 \mathrm{~mm}$ thick on average; large pseudopores, $0.017 \mathrm{~mm}$ diameter on average, present in distal autozoecial walls. Kenozooecial walls composed of a single granular layer, $0.008 \mathrm{~mm}$ thick on average.

Discussion. - Following Buttler's (1989) emended diagnosis, the Iberian material shares with Kukersella the zoarium size and growth habit, the autozooecia and kenozooecia development patterns in the exozone and endozone, respectively, the presence of peristomes in autozooecial apertures, as well as interzooecial pores and pseudopores in the autozooecial walls.
The features seen in this material correspond with the description given by Buttler (1989) of Kukersella borealis (Bassler 1911). I am in agreement with her regarding the impossibility of distinguishing it from Kukersella bassleri Toots, 1952 and Kukersella singularis (Ross 1967a) taking into account the generally used characters of pseudopore diameters and number of kenozooecia in the endozone. In the material from the Iberian Chains, the diameter of the pseudopores is not constant, ranging from $0.005 \mathrm{~mm}$ to $0.04 \mathrm{~mm}$, and the number of kenozooecia in the endozone depends on the position along the branch.

Occurrence. - Orthoceras Limestone (Darriwilian) in Port Kunda (Bassler 1911); in the Wassalem bed (lower Katian) in Uxnorm (Bassler 1911); Kukers Shale and Wesenberg Limestone (upper Darriwilian-lower Katian) (Toots 1952); all of them in Estonia. Rockland and Kirkland Formations (Sandbian-lower Katian) in New York (Ross 1967a). In erratic blocks in North and Central Poland and the Mójcza Limestone (Poland), Floian-Katian in age (Dzik 1981). Llanbedrog Limestones (upper Sandbian) in Gwynedd, Wales (Buttler 1991b). Punta S'Agiola Member, lower Domus-Novas Formation (upper Katian) in Sardinia, Italy (Conti 1990). Crug Shale and Slade and Redhill beds (Hirnantian) in Dyfed, Wales (Buttler 1991a). Tripolitania Formation (upper Katian) in Djeffara, Libya (Buttler et al. 2007). Pin Formation, Upper Katian, in India (Suttner \& Ernst 2007). The siltstone/sandstone member of the Uggwa Formation (upper Katian) in Valbertad, Carnic Alps, Italy, and the carbonate and clastic sequence from Montagne Noire, France (Ernst \& Key 2007). La Peña (layers 3, 4, 6-9 and 12) and Rebollarejo (layers 6 and 12) members, the Valdelaparra section, Fombuena, and Rebosilla Member (layer 6), Luesma 2 section, Luesma; both sections in the Zaragoza province.

Order Fenrstrata Astrova \& Morozova, 1956 Family Phylloporinidae Ulrich, 1890

\section{Genus Chasmatopora Eichwald, 1855}

Type species. - Retepora tenella Eichwald, 1855. Upper Ordovician of Vormsi (Estonia).

\section{Chasmatopora hypnoides (Sharpe, 1853)}

Figure 25D-F, Table 13

1853 Synocladia hypnoides n. sp.; Sharpe, p. 147, pl. 7, fig. 10.

1880 Dictyonema? corniculata sp. nov.; Meneghini, p. 216, pl. 1, 6 .

1910 Fenestella (Reteporina) carnica n. sp; Vinassa de Regny, p. 17, pl. 2, figs 12-14. 
1936 Chasmatoporella metzi sp. nov.; Nekhoroshev, p. 7, pl. 1, fig. 1.

1940 Chasmatoporella metzi Nekhoroshev, 1936. - Prantl, p. $87,1.1$, figs 2,3 .

1942 Fenestella (Reteporina) corniculata (Meneghini, 1880). - Vinassa de Regny, pp. 1033, 1034, pl. 2, figs 5,6 .

1942 Protocrisina sardoa n. sp.; Vinassa de Regny, p. 1027, pl. 1, fig. 10, text-fig. A.

1948 Phylloporina hypnoides (Sharpe, 1853). - Dreyfuss, p. 33, pl. 4, figs 11, 11a, 12, pl. 9, fig. 11.

1968 Chasmatoporella sp.; Annoscia, p. 221, pl. 7, fig. 1.

1985 Chasmatopora metzi (Nekhoroshev, 1936). - Lavrentjeva, p. 45, pl. 17, fig. 2.

1988 Graptodictya sp.; Conti \& Serpagli, pl. 11, figs 4-6.

1990 Chasmatopora corniculata (Meneghini, 1880). Conti, pp. 112, 113, pl. 19, figs 3-12, pl. 22, fig. 6.

2001 Moorephylloporina hypnoides (Sharpe, 1853). - Morozova, p. 41.

2007 Chasmatopora hypnoides (Sharpe, 1853). - Ernst \& Key, p. 56, pl. 21, figs 9-15, pl. 22, figs 1-3.

2007 Chasmatopora sp.; Jiménez-Sánchez et al., fig. 6(6).

Material. - Two external zoarial molds (MPZ 2008/169); eleven zoarial fragments in transversal section (MPZ 2006/186, MPZ 2006/256, MPZ 2006/261, MPZ 2006/266-272 and MPZ 2006/274); five zoarial fragments in longitudinal section (MPZ 2006/257, 258, MPZ 2006/264, 265 and MPZ 2006/275); one zoarium in longitudinal and transversal section (MPZ 2006/263); and one zoarium in tangential section (MPZ 2006/262).

Description. - Zoaria with cribated growth habit, anastomosed in shape, $120 \mathrm{~mm}$ wide and $201 \mathrm{~mm}$ tall. Fenestrulae irregularly elongated, with large axis $5 \mathrm{~mm}$ long on average and small axis $2.3 \mathrm{~mm}$ long on average, with large axis parallel to zoarium growth direction. Fenestrula components (or zoarial fragments) four-sided polygonal or circular, with $0.55 \mathrm{~mm}$ diameter on average. Autozooecia without internal structures, arranged in four longitudinal rows, two median and two lateral, open to the obverse side; reverse side with longitudinal narrow grooves. Autozooecial apertures oval in shape with large diameter of $0.15 \mathrm{~mm}$ on average and with large peristome around them; autozooecial length almost eight times its average diameter; growing parallel to the zoarial growth direction during the majority of their development but suddenly bending and terminating at the external surface at an angle of $81^{\circ}$ on average; autozooecia budding from a central axis in two series: the initial one forming central longitudinal rows, and the later one forming lateral longitudinal rows. Heterozooecia present, but scarce. Autozooecial walls laminated, $0.019 \mathrm{~mm}$ thick on average in the endozone, in the exozone $0.15 \mathrm{~mm}$ thick on the obverse side
Table 13. Summary of the statistical analysis of Chasmatopora hypnoides (Sharpe, 1853). Abbreviations as in Table 1.

\begin{tabular}{lccrrrr}
\hline Character & Or & X & DS & Nm & Nsp \\
\hline $\begin{array}{l}\text { Autozooecial angles with } \\
\text { zoarial surface }\end{array}$ & $65^{\circ}-88^{\circ}$ & $81^{\circ}$ & 8 & 6 & 4 \\
$\begin{array}{l}\text { Autozooecial large diameter } \\
\text { (in mm) }\end{array}$ & $0.09-0.03$ & 0.15 & 0.05 & 91 & 19 \\
$\begin{array}{l}\text { Autozooecial wall thickness } \\
\text { (in mm) }\end{array}$ & $0.01-0.04$ & 0.019 & 0.006 & 68 & 18 \\
$\begin{array}{l}\text { Fenestrula large axis } \\
\text { (in mm) }\end{array}$ & $6-3$ & 5 & 1 & 21 & 2 \\
$\begin{array}{l}\text { Fenestrula small axis (in } \\
\text { mm) }\end{array}$ & $1.5-4$ & 2.3 & 0.6 & 21 & 2 \\
$\begin{array}{l}\text { Obverse thickness (in mm) } \\
\text { Reverse thickness (in mm) }\end{array}$ & $0.04-0.27$ & 0.15 & 0.07 & 18 & \\
$\begin{array}{l}\text { Zoarial wide (in mm) } \\
\text { Zoarial fragment diameter } \\
\text { (in mm) }\end{array}$ & $0.34-1.32$ & 0.12 & 0.06 & 22 & 11 \\
Zoarial height & 120 & 0 & 2 & 2 \\
\hline
\end{tabular}

and $0.12 \mathrm{~mm}$ thick on average on the reverse side, respectively.

Discussion. - The following features have allowed the inclusion of the studied material in Chasmatopora, according to Ernst \& Key's (2007) emended diagnosis: the zoaria growth habit and its anastomosed shape; the autozooecia budding from a central axis, arranged in four longitudinal rows; the autozooecial apertures with peristomes, frontally and laterally open; the presence of grooves on the reverse side; as well as the autozooecial cross sections being oval in shape. Up to now, only a single species of Chasmatopora has been identified from the Mediterranean margin of Gondwana: Chasmatopora hypnoides (Sharpe, 1853). This species was originally described from the upper Katian of Portugal (Sharpe 1853) and subsequently identified from the Montagne Noire in France (Dreyfuss 1948 and Ernst \& Key 2007), in Sardinia (Conti 1990) and in the Carnic Alps (Vinassa de Regny 1942) with different names (see synonymies). The fenestrula irregular shape, the size and shape of the fenestrula components, the large length of autozooecia without internal structures, the presence of a well-developed peristome, and the presence of heterozooecia clearly allow the inclusion of the Iberian material in the same species.

Occurrence. - Porto do Santa Anna Formation, upper Katian of Buçaco (Portugal), Sharpe (1853); carbonate and clastic sequence from the Montagne Noire (France), upper Katian, Dreyfuss (1948) and Ernst \& Key (2007); Uggwa Formation, upper Katian of Carnic Alps, Vinassa de Regny (1942); c and e beds, upper Ordovician, Sardinia (Italy), 
Conti (1990); the La Peña Member (layers 1, 6, 7, 11 and 12) in the Valdelaparra section (Fombuena, Zaragoza) and the Rebosilla Member (layer 23) in Luesma 2 section (Luesma, Zaragoza), Iberian Chains.

\section{Genus Pseudohornera Roemer, 1876}

Type species. - Retepora diffusa Hall, 1852. Niagara Limestone Formation, Lower Silurian of New York and Canada.

\section{Pseudohornera sp.}

Figures 30A-D, 31, 32, Table 14

Material. - One zoarial fragment in tangential and longitudinal section (MPZ 2006/105); three zoarial fragments in longitudinal section (MPZ 2006/100, MPZ 2006/135 and MPZ 2006/137); four zoarial fragments in transversal section (MPZ 2006/138, 139, MPZ 2006/141, 142); and six zoarial fragments in oblique section (MPZ 2006/101-104, MPZ 2006/136 and MPZ 2006/140).

Description. - Zoaria with a branching growth habit, with branches being circular in cross section, $0.99 \mathrm{~mm}$ diameter on average. Obverse side with autozooecial apertures arranged in four to six longitudinal rows and with prominent peristome; reverse side without apertures and composed of a succession of zoarial growth stages; growth stages with light, thickened, laminated internal zone and dark, thin, laminated external zone; 4 growth stages on average in reverse, with a thickness of $0.06 \mathrm{~mm}$ on average per growth stages. Autozooecial apertures subcircular to oval, with large diameter $0.22 \mathrm{~mm}$ and small diameter $0.14 \mathrm{~mm}$, on average; large axis parallel to zoarial growth direction; autozooecial boundaries marked by a thick dark layer. Two types of autozooecia: those situated near the reverse side growing parallel to the branch, but suddenly bending to terminate at the zoarial surface; and those situated on the front side initially growing at an angle of $13^{\circ}$ on average, and then slightly bending to form a $21^{\circ}$ angle on average with the external surface; autozooecial cross section irregularly polygonal in the endozone and subelliptical in the exozone. Acanthostyles composed of light massive calcite, developed at the autozooecial boundaries where the autozooecia bend, $0.02 \mathrm{~mm}$ diameter on average. Autozooecial walls concentrically laminated around the autozooecial apertures, $0.07 \mathrm{~mm}$ thick in the exozone; autozooecial walls composed of three layers in the endozone: one granular central layer and two laminated external layers, $0.017 \mathrm{~mm}$ thick on average. Small pore-like structures may be present on the reverse side.

Discussion. - According to Brood's (1970) and Ernst \& Key's (2007) emended diagnoses, the following characters allow this Iberian material to be included in Pseudohornera Roemer, 1876: zoaria with branching growth habit; the autozooecia open only to the obverse side; the wall microstructure in the exozone and the endozone; and the presence of small acanthostyles. In spite of the numerous thin sections studied, it is preferable not to assign this material to any precise species due to lack of certainty that all the fragments belong to a single species. Nevertheless, this material is similar to Pseudohornera dimitrii Ernst \& Key, 2007, described from the upper Katian of the Montagne Noire (France), but they can be distinguished because in the Iberian material the acanthostyles are only present on the obverse side, while in Pseudohornera dimitrii the acanthostyles are also present on the reverse side.

Occurrence. - The La Peña Member, in the Valdelaparra section (layers 1, 6, 7 and 11) and in La Peña del Tormo section (Fombuena, Zaragoza).

Table 14. Summary of the statistical analysis of Pseudohornera sp. Abbreviations as in Table 1.

\begin{tabular}{|c|c|c|c|c|c|}
\hline Character & Or & $\mathrm{X}$ & DS & $\mathrm{Nm}$ & Nsp \\
\hline Acanthostyles diameter (in mm) & $0.01-0.03$ & 0.02 & 0.01 & 31 & 8 \\
\hline Autozooecial angle in endozone & $3^{\circ}-32^{\circ}$ & $13^{\circ}$ & 10 & 7 & 3 \\
\hline Autozooecial angle with zoarial surface & $13^{\circ}-32^{\circ}$ & $21^{\circ}$ & 7 & 10 & 3 \\
\hline Autozooecial large diameter (in mm) & $0.16-0.33$ & 0.22 & 0.06 & 33 & 8 \\
\hline Autozooecial small diameter (in mm) & $0.11-0.19$ & 0.14 & 0.02 & 43 & 8 \\
\hline Autozooecial wall thickness in endozone (in mm) & $0.010-0.035$ & 0.017 & 0.004 & 94 & 14 \\
\hline Autozooecial wall thickness in exozone (in mm) & $0.02-0.18$ & 0.07 & 0.1 & 53 & 12 \\
\hline Growth stage thickness (in mm) & $0.03-0.13$ & 0.06 & 0.02 & 77 & 10 \\
\hline Number of growth stages & $3-7$ & 4 & 1 & 10 & 10 \\
\hline Zoarial diameter (in $\mathrm{mm}$ ) & $0.60-1.47$ & 0.99 & 0.28 & 41 & 13 \\
\hline
\end{tabular}


Order Trepostomata Ulrich, 1882

Family Halloporidae Bassler, 1911

\section{Genus Calloporella Ulrich, 1882}

Type species. - Calloporella harrisi Ulrich, 1882. Richmond Formation, Upper Ordovician of Ohio and Indiana (USA).

\section{Calloporella sp.}

Figure 30E, Table 15

Material. - One zoarium in longitudinal section (MPZ 2006/175); and one zoarium in longitudinal-oblique section (MPZ 2006/255); all sections are perpendicular to the zoarial growth direction.

Description. - Zoarium with encrusting growth habit, composed of a single layer $1.5 \mathrm{~mm}$ thick on average and with apparent diameter $22.5 \mathrm{~mm}$. Autozooecia tubular with apparent diameter of $0.35 \mathrm{~mm}$ on average and 1.4 autozooecia per $\mathrm{mm}$ on average; autozooecia growing obliquely with respect to the basal surface, but in initial stages bending to form a $90^{\circ}$ angle with the zoarial external surface. Diaphragms scarce, with no more that one per autozooecium. Mesozooecia tubular, with apparent diameter of $0.18 \mathrm{~mm}$ on average and 3 mesozooecia per $\mathrm{mm}$, on average, densely tabulated by diaphragms, with 6 of these structures per $\mathrm{mm}$ on average; mesozooecia growing from the basal surface isolating autozooecia or in small groups forming maculae. Zooecial walls finely laminated, slightly thickened in the exozone; with autozooecial-mesozooecial wall $0.012 \mathrm{~mm}$ thick and mesozooecial-mesozooecial wall $0.01 \mathrm{~mm}$ thick, on average.

Discussion. - According to Pushkin's (1981) diagnosis the following characters allow these zoaria to be included in Calloporella: the zoarial encrusting growth habit, the thickness and microstructure of zooecial walls, and the abundance of mesozooecia, densely tabulated by diaphragms. Although, there are no transversal sections that permit classifying these zoaria at the species level, their longitudinal sections have been compared with these other species described by Pushkin (1981) as Upper Ordovician in age. The Iberian Calloporella can be distinguished from Calloporella schmidti Pushkin, 1981, and from Calloporella septata Pushkin, 1981, because their autozooecial diaphragms are more numerous and autozooecia are larger than average in the maculae, while in the Iberian material maculae are exclusively composed of mesozooecia. In addition, Calloporella septata has less mesozooecia than the two zoaria studied here. The Iberian material can be distinguished from Calloporella serotina Pushkin, 1981, because in the latter the autozooecia grow forming an angle of $90^{\circ}$ with the basal surface and the mesozooecia do not isolate autozooecia as in the Iberian Calloporella. It can be distinguished from Calloporella concinna Pushkin, 1981, because the latter has more autozooecial diaphragms and also the mesozooecia do not isolate autozooecia. Finally, Calloporella tauchenisensis Pushkin, 1981, can be distinguished from all other species, including the Iberian Calloporella, because its zoarium is composed of two symmetrical layers.

Occurrence. - The La Peña Member (layers 4 and 7) in the Valdelaparra section (Fombuena, Zaragoza).

\section{Genus Diplotrypa Nicholson, 1879}

Type species. - Favosites petropolitanus Pander, 1830. Middle Ordovician of Sweden.

Discussion. - Nicholson (1879) described Diplotrypa as a subgenus of Monticulipora d'Orbigny, 1850, with Favosites petropolitanus Pander, 1830, as the type species. Ulrich (1890) defined the family Diplotrypidae to include Diplotrypa, which was elevated to genus level, plus Batostoma Ulrich, 1882, and Monotrypa Nicholson, 1879. Nickles \& Bassler (1900) moved all these genera into the family Trematoporidae. Astrova (1978) made a revision of Diplotrypa including it into the family Halloporidae but without giving any reason for this change. Conti (1990), following McKinney's (1971) revision of the family Diplotrypidae, moved Diplotrypa back into this family. Conti (1990) based the reallocation on the reduced thickness of the zooecial walls both in the endozone and the exozone, which distinguishes Diplotrypa from the Trematoporidae genera, and in the astogenetic pattern of Diplotrypa, with autozooecia budding from mesozooecia in the endozone, which distinguishes it from the Halloporidae genera. Key (1991) emended the diagnosis of Diplotrypa and moved it back again into the family Halloporidae, emending the diagnosis of this family.

\section{Diplotrypa gemmata (Conti, 1990)}

Figures 33A-C, 34, Table 16

1990 Panderpora gemmata n. sp.; Conti, p. 102, pl. 10, figs 4-8, pl. 11, figs 1, 2.

2007 Diplotrypa sp.; Jiménez-Sánchez, Spjeldnaes \& Villas, fig. $7(1,2)$.

Material. - One zoarium in longitudinal and tangential section (MPZ 2006/112).

Description. - Zoarium with massive growth habit, hemispherical in shape and with slightly concave basal surface, 
Table 15. Summary of the statistical analysis of Calloporella sp. Abbreviations as in Table 1.

\begin{tabular}{|c|c|c|c|c|c|}
\hline Character & Or & $\mathrm{X}$ & DS & $\mathrm{Nm}$ & Nsp \\
\hline Autozooecial diameter (in mm) & $0.27-0.40$ & 0.35 & 0.04 & 19 & 2 \\
\hline Autozooecial-mesozoecial wall thickness (in mm) & $0.01-0.02$ & 0.012 & 0 & 15 & 2 \\
\hline Mesozooecial diameter (in mm) & $0.12-0.27$ & 0.18 & 0.04 & 25 & 2 \\
\hline Mesozooecial-mesozooecial wall thickness (in mm) & $0.005-0.01$ & 0.01 & 0.002 & 19 & 2 \\
\hline Number of autozooecia per $1 \mathrm{~mm}$ & $0.5-2$ & 1.4 & 0.6 & 12 & 2 \\
\hline Number of mesozooecial diaphragms per $1 \mathrm{~mm}$ & $2-9$ & 6 & 2 & 16 & 2 \\
\hline Number of mesozooecia per $1 \mathrm{~mm}$ & $1-4$ & 3 & 1 & 11 & 2 \\
\hline Zoarial apparent length (in mm) & $21-24$ & 22.5 & 2.1 & 2 & 2 \\
\hline Zoarial height (in mm) & $1-2.3$ & 1.5 & 0.5 & 8 & 2 \\
\hline
\end{tabular}

Table 16. Summary of the statistical analysis of Diplotrypa gemmata (Conti, 1990). Abbreviations as in Table 1.

\begin{tabular}{|c|c|c|c|c|c|}
\hline Character & Or & $\mathrm{X}$ & DS & $\mathrm{Nm}$ & Nsp \\
\hline Autozooecial diameter (in mm) & $0.49-0.66$ & 0.57 & 0.06 & 18 & 1 \\
\hline Zooecial wall thickness (in mm) & $0.01-0.03$ & 0.02 & 0 & 19 & 1 \\
\hline Brown body diameter (in mm) & $0.13-0.24$ & 0.17 & 0.04 & 8 & 1 \\
\hline Mesozooecial diameter (in mm) & $0.09-0.39$ & 0.19 & 0.08 & 20 & 1 \\
\hline Number of autozooecia per 1 square mm & $3-4$ & 3.3 & 0.6 & 3 & 1 \\
\hline Number of autozooecia per $2 \mathrm{~mm}$ & $2-4$ & 2.7 & 0.7 & 7 & 1 \\
\hline Number of mesozooecial diaphragms per $1 \mathrm{~mm}$ & $6-11$ & 8.5 & 1.5 & 20 & 1 \\
\hline Number of mesozooecia per 1 square mm & $6-11$ & 8.2 & 2.5 & 3 & 1 \\
\hline Number of mesozooecia per $2 \mathrm{~mm}$ & $3-4.5$ & 3.7 & 0.6 & 7 & 1 \\
\hline Zoarial diameter (in mm) & 32 & 32 & 0 & 1 & 1 \\
\hline Zoarial height (in mm) & 18.5 & 18.5 & 0 & 1 & 1 \\
\hline
\end{tabular}

with a maximum diameter of $32 \mathrm{~mm}$ and a maximum height of $18.5 \mathrm{~mm}$. Autozooecial apertures subpolygonal or subcircular, $0.57 \mathrm{~mm}$ diameter on average, isolated by mesozooecia; 2.7 autozooecial apertures per $2 \mathrm{~mm}$ and $3.3 \mathrm{au}-$ tozooecial apertures per $\mathrm{mm}^{2}$, on average. Autozooecia tubular with two astogenetic patterns. (1) Autozooecia radiating directly from the zoarium base, characterized by a larger diameter, sinuous walls and occasional diaphragms, only present in the proximal autozooecial zone in some autozooecia. (2) Autozooecia budding from mesozooecia. This second autozooecial pattern occurs in two ways: first and most common in the proximal mesozooecial zone, consisting of the termination of mesozooecial diaphragms and progressive increase in zooecial diameter; and second one occurs in the distal mesozooecial zone where autozooecia develop from two or three small mesozooecia; this transformation occurs at a point where a group of mesozooecia have the diaphragm at the same level; here, diaphragm production ceases and a small autozooecium with a pair of basal diaphragms develops.
Brown body structures, $0.17 \mathrm{~mm}$ diameter on average, are present in some autozooecia. Mesozooecial apertures polygonal or subcircular, $0.19 \mathrm{~mm}$ diameter on average, but with a large variability, $0.09-0.39 \mathrm{~mm}$, isolating autozooecia or forming small maculae; 3.7 mesozooecial apertures per $2 \mathrm{~mm}$ and 8.2 mesozooecial apertures per $\mathrm{mm}^{2}$, on average. Three types of mesozooecial astogenetic patterns were found: (1) mesozooecia developed at the zoarium base, characterised by a large diameter and either reaching the external zoarial surface, or transforming into autozooecia; (2) mesozooecia budding from other mesozooecia, when situated above a mesozooecial diaphragm, another mesozooecial wall is generated; and (3) mesozooecia budding from other mesozooecia, but in this process also generating an autozooecium. All mesozooecia densely tabulated by diaphragms, 8.5 of these structures per $\mathrm{mm}$ on average. Zooecial walls laminated, $0.02 \mathrm{~mm}$ thick on average, with layers parallel to the zoarium growth direction and without any thickness change between the exozone and endozone. 

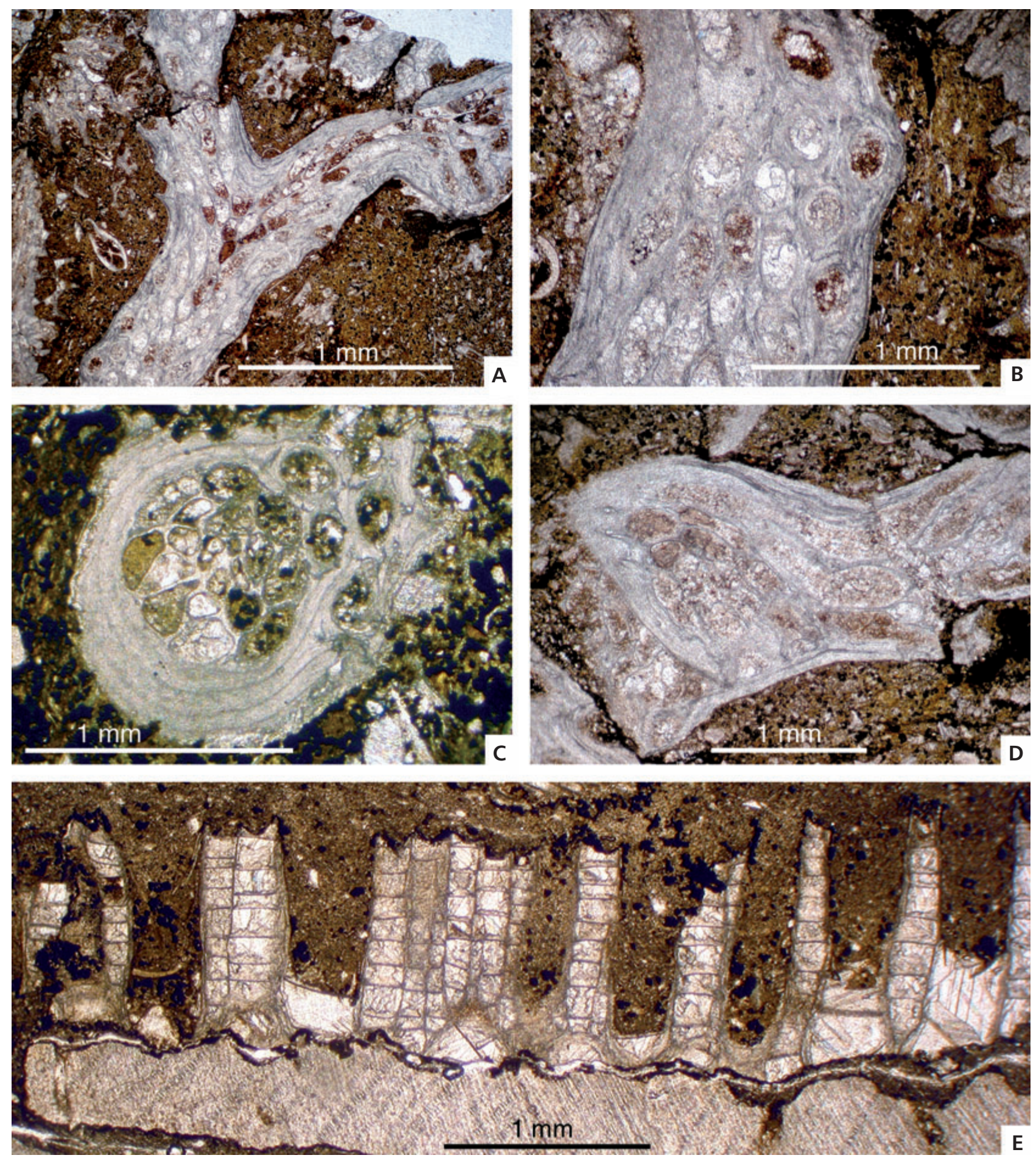

Figure 30. A-D - Pseudohornera sp. A, B - MPZ 2006/105; A - longitudinal section; B - tangential section; C - MPZ 2006/136, transversal section; D - MPZ 2006/102, oblique section in which small acanthostyles (on the left) can be observed. • E - Calloporella sp. MPZ 2006/175, longitudinal section. A, B and C from the La Peña Member in the La Peña del Tormo section, C and E from the La Peña Member in the Valdelaparra section (Fombuena, Zaragoza).

Discussion. - Bassler (1952) described the new genus Panderpora, including in it species closely related to Hallopora Bassler, 1911. Astrova (1978) considered Pander- pora as a junior synonym of Diplotrypa. Conti (1990) drew freehand astogenetic patterns of the genera Hallopora, Panderpora and Diplotrypa, showing the way in which au- 


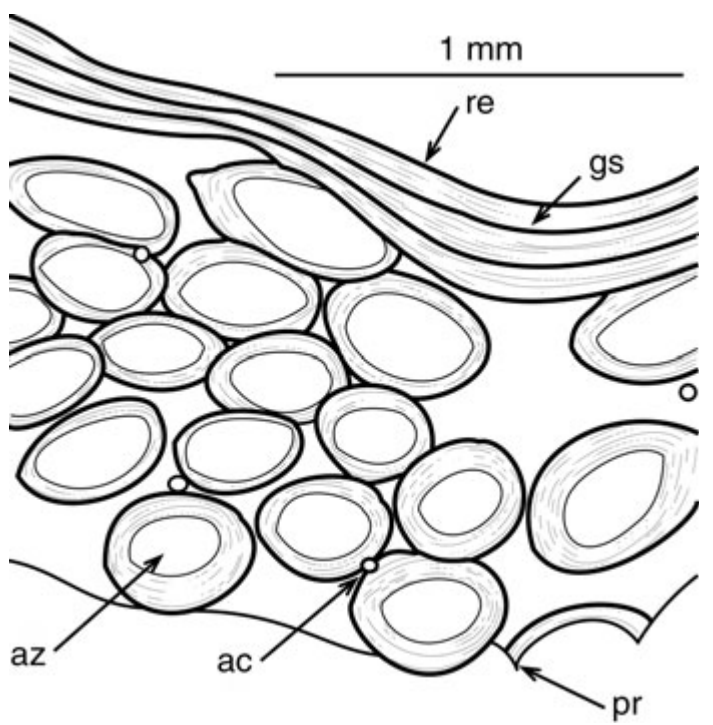

Figure 31. Pseudohornera sp. Schematic tangential section of the zoarium MPZ 2006/105 showing oval to subcircular autozooecial apertures (az) with peristome (pr), small acanthostyles (ac), and reverse with growth stages (gs).

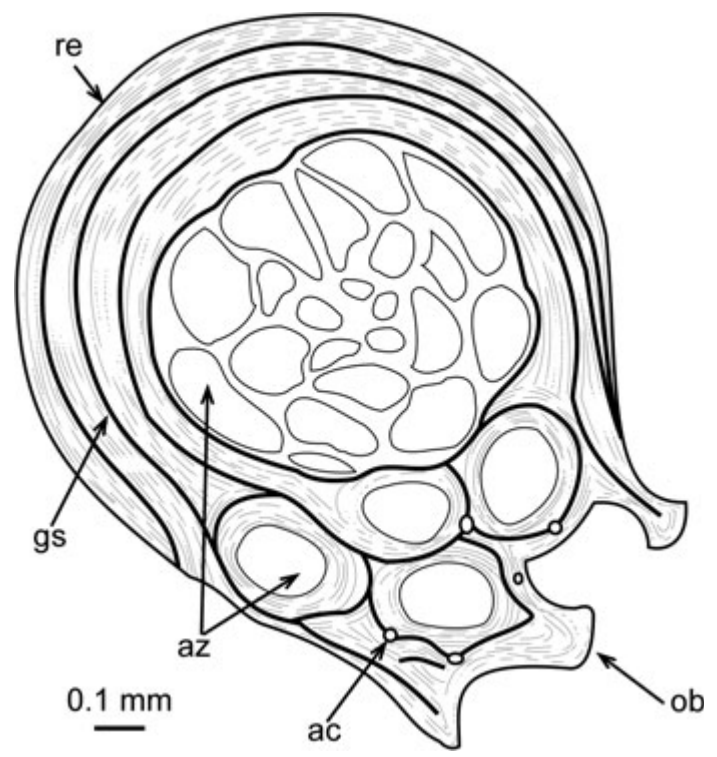

Figure 32. Pseudohornera sp. Schematic transversal section of the zoarium MPZ 2006/136 showing obverse (ob) with autozooecial apertures, autozooecia (az) sections irregular in endozone and regular in exozone, small acanthostyles (ac), and reverse (re) with growth stages (gs).

tozooecia bud from mesozooecia and vice versa. Diplotrypa and Panderpora show a different astogenetic pattern and Conti (1990), based on this fact, considered them as two different genera. Key (1991) also considered Panderpora as a junior synonym of Diplotrypa, including in it species with the typical growth habit of the halloporids, where autozooecia arise from mesozooecia by astogenetic transformation. In the zoarium studied here, the astogenetic pat- terns described by Conti (1990) for Diplotrypa and Panderpora are both present. This fact can indicate that the astogenetic pattern is not a valid diagnostic generic feature and thus, Panderpora is here also considered as a junior synonym of Diplotrypa.

The Iberian zoarium shows two of the three diagnostic characters of Diplotrypa gemmata (Conti, 1990), defined from the upper Katian of Sardinia: endozone-exozone boundary well defined and the astogenetic patterns of autozooecia and mesozooecia. No phosphatic autozooecial diaphragm has been found in the Iberian zoarium, this being the third diagnostic feature according to Conti (1990). However, since the phosphatic composition of autozooecial diaphragms is a product of diagenesis, this feature should not be considered as diagnostic. The Iberian material and Diplotrypa gemmata share the same shape, the diameter and the height of the zoarium; the same astogenetic pattern characterized by budding of autozooecia from mesozooecia; the rare autozooecial diaphragms; as well as the distribution of mesozooecial diaphragms and the winding of its walls. Due to these shared characters, the Iberian material can be clearly assigned to Diplotrypa gemmata.

Following Key's (1991) emended diagnosis, Diplotrypa gemmata can be included in Diplotrypa because it shares with it the main diagnostic characters. They are: the massive growth habit and the hemispherical shape of the zoarium; the presence of maculae composed of larger mesozooecia; the astogenetic patterns of the autozooecia and mesozooecia; the distribution of the mesozooecia isolating the autozooecia or in small groups, forming maculae; the composition and thickness of zooecial walls; the large autozooecial apertures; and the absence of acanthostyles. The Mediterranean species differs from Key's (1991) emended diagnosis in that its autozooecial diaphragms are really scarce and the endozone-exozone boundary is very clear. But the species included in Diplotrypa have a wide range in number and shape of the autozooicial diaphragm. Therefore, this species is assigned to Diplotrypa without any doubt.

Diplotrypa sardoa Conti, 1990, and Diplotrypa languedociana Dreyfuss, 1948, were previously described from the Mediterranean margin of Gondwana in the upper Katian of Sardinia (Conti 1990) and the Montagne Noire (Dreyfuss 1948, Ernst \& Key 2007), respectively. Diplotrypa gemmata can be distinguished from Diplotrypa sardoa and Diplotrypa languedociana because in the latter two species there are no differences between the endozone and the exozone. In addition, Diplotrypa gemmata can be distinguished from Diplotrypa sardoa because in the latter the autozooecia are bottle-shaped and has cystoidal diaphragms and cystiphragms; Diplotrypa gemmata can be distinguished from Diplotrypa languedociana by the presence of acanthostyles. 

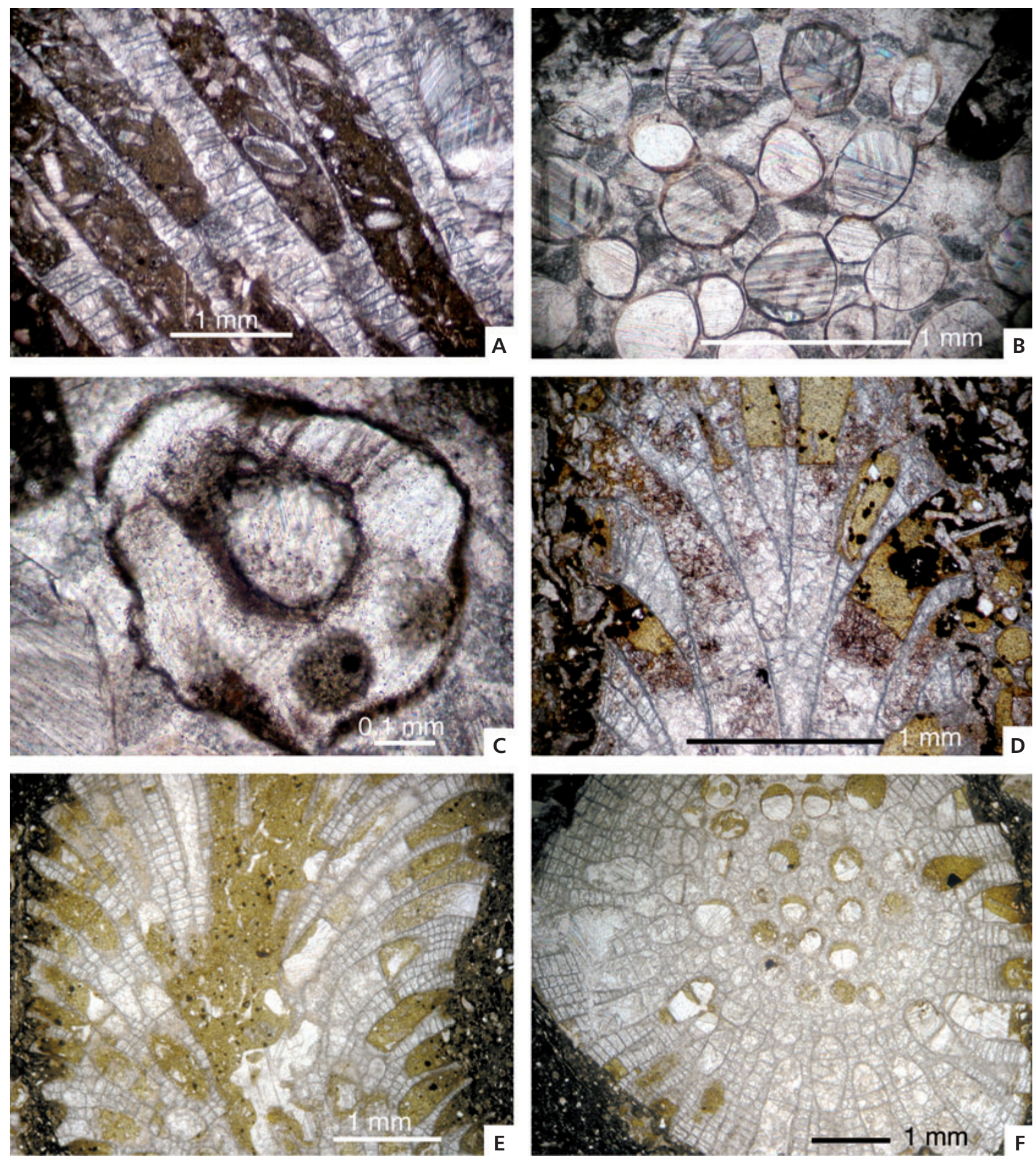

Figure 33. A-C - Diplotrypa gemmata (Conti, 1990), MPZ 2006/112. A - longitudinal section; B - transversal section; C - brown body in an autozooecium. • D-F - Hallopora elegantula (Hall, 1851). D - MPZ 2006/280, longitudinal section; E, F - MPZ 2006/190; E - longitudinal section; F - transversal section. All specimens from the La Peña Member in the Valdelaparra section (Fombuena, Zaragoza).

Occurrence. - Punta S'Argiola Member, lower beds of Domus-Novas Formation, upper Katian (Sardinia, Italy) (Conti 1990); the La Peña Member (layer 11), in the Valdelaparra section (Fombuena, Zaragoza).
Genus Hallopora Bassler, 1911

Type species. - Calopora elegantula Hall, 1851. Niagara Limestone Formation, Lower Silurian of Lockport and New York (USA). 

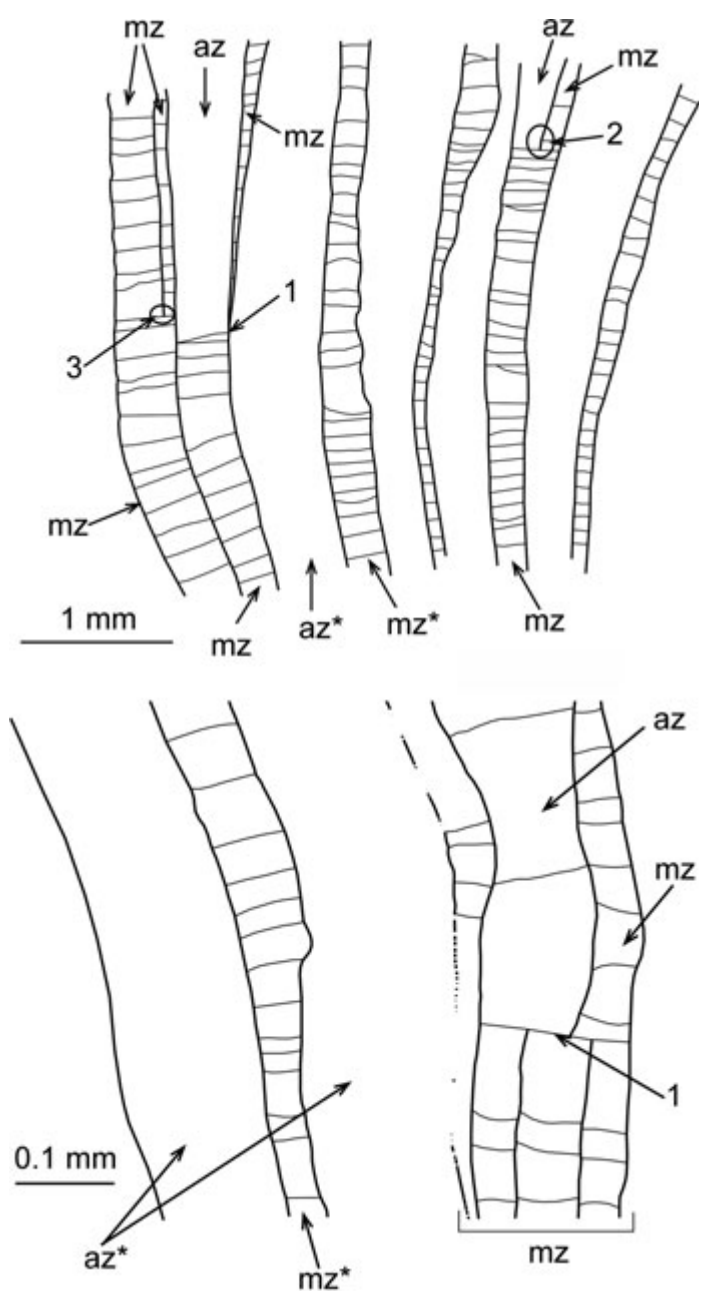

A

Figure 34. Diplotrypa gemmata (Conti, 1990). Schematic longitudinal sections showing the different types of autozooecia and mesozooecia. In both, the large tubes without diaphragms represent the autozooecia growing from the zoarial base (az*) while the large tubes densely tabulated by diaphragms represent the mesozooecia growing from the zoarial base and reaching the zoarial surface $\left(\mathrm{mz}^{*}\right)$. In (A) numbers 1 and 2 show the generation of autozooecia from mesozooecia by the mechanism of termination of diaphragms and development of an associated mesozooecium, conical in 1 and tubular in 2; and number 3 shows the generation of one mesozooecium from a preexisting one. In (B) number 1 shows the development of an autozooecium and one associated mesozooecium from three mesozooecia.

Hallopora elegantula (Hall, 1851)

Figures 33D-F, 35, Table 17

1851 Calopora elegantula n. sp.; Hall, p. 400.

1990 Hallopora elegantula (Hall, 1851). - Conti, p. 100, pl. 8, fig. 8, pl. 9, figs 1-6; and synonymy there cited.

2007 Hallopora elegantula (Hall, 1851). - Ernst \& Key, p. 382, pl. 7, figs $4-8$.

2007 Hallopora sp.; Jiménez-Sánchez et al., fig. 7 (7, 8).

Material. - One zoarium in longitudinal and transversal section (MPZ 2006/190); four zoarial fragments in trans- versal and oblique section (MPZ 2006/278, MPZ 2006/281, 282 and MPZ 2006/285); and six zoarial fragments in transversal section (MPZ 2006/279, 280, MPZ 2006/283, 284, MPZ 2006/287 and MPZ 2006/290).

Discussion. - There is no tangential section available and autozooecial and mesozooecial diameters have been measured in longitudinal and transversal sections only, so these values are estimates and the real values could be higher. The linear density of autozooecia and mesozooecia has been measured in longitudinal sections, therefore real density also may be less than the value obtained here.

Description. - Zoaria with branching growth habit, branches with circular cross section, $3.4 \mathrm{~mm}$ diameter on average. Autozooecia tubular, $0.33 \mathrm{~mm}$ diameter on average, budding in the endozone and growing parallel to the zoarial growth direction, but bending slightly in the outer endozone; in the inner exozone, autozooecia bend strongly to reach the external zoarial surface at an angle of $60^{\circ}$ on average; autozooecial diaphragms mainly in the inner exozone and irregularly distributed; autozooecial cross section circular to subpolygonal in the endozone; 3.2 autozooecia per $2 \mathrm{~mm}$. Mesozooecia develop in the outer endozone where autozooecia bend towards the external zoarial surface; wedge-shaped proximally and progressively becoming tubular distally, with an average diameter of $0.16 \mathrm{~mm}$; mesozooecial diaphragms abundant, 14 per $\mathrm{mm}$ on average, with clear laminated microstructure; mesozooecia isolating autozooecia or in groups forming maculae; 7.3 mesozooecia per $2 \mathrm{~mm}$. Astogenetic budding of autozooecia from mesozooecia and also vice versa; budding of autozooecia from mesozooecia occurs in the inner exozone by termination of mesozooecial diaphragms and an increase in autozooecial diameter. Budding of mesozooecia from autozooecia occurs in the outer exozone by the development of cap-like structures (Conti \& Serpagli 1987). Autozooecial walls laminated with layers parallel to autozooecial growth direction, without any change in thickness at the endozone-exozone boundary, $0.011 \mathrm{~mm}$ thick on average; mesozooecial walls laminated with an inverse V pattern, slightly thinner than autozooecial walls. Lamination forming mesozooecial diaphragms also including part of mesozooecial wall lamination. Endozone and exozone well defined, with similar diameter and width.

Discussion. - The branching growth habit of the zoarium, the presence of cap-like structures (present in many species of the genus), well defined endozone and exozone, the distribution of autozooecial and mesozooecial diaphragms, and the absence of acanthostyles, are the characters that have allowed this material to be included in the genus Hallopora following Ernst \& Key's (2007) emended diagnosis. 
The features described in the Iberian material correspond with those described by Conti (1990) and Ernst \& Key (2007) in Hallopora elegantula (Hall, 1851) from the upper Katian of Sardinia (Italy) and the Montagne Noire (France), respectively, but the Iberian zoaria lack mural spines in the autozooecia. However, not all the material assigned to Hallopora elegantula have these structures (Spjeldnaes 1984, from the Upper Ordovician of the Baltic); therefore, the mural spines do not appear to have diagnostic value and the zoaria studied are thus included in Hallopora elegantula.

Hallopora cystoidalis Conti, 1990, Hallopora edonis Bassler, 1927, Hallopora furumjuliensis (Vinassa de Regny 1910) and Hallopora gracilens Bassler, 1927 are other species of the genus described previously from the Mediterranean margin of Gondwana [see Conti (1990) and Ernst \& Key (2007)]. This Iberian material assigned to Hallopora elegantula can be distinguished from Hallopora cystoidalis because in the latter the zoarium is larger, the autozooecia bud from mesozooecia also in the endozone, the autozooecial diaphragms are more numerous in the exozone, and the cap-like structures are absent. From Hallopora edonis it can be distinguished because in this species the autozooecia reach the external surface at a broader angle, the autozooecia lack cap-like structures, the mesozooecia are restricted to the exozone and are more numerous, and have thicker autozooecial walls in the exozone. From Hallopora furumjuliensis it can be distinguished because in this species the autozooecia bud from mesozooecia also in the endozone, and the autozooecia reach the external surface at a broader angle. And, finally, the Iberian material can be distinguished from Hallopora gracilens because in the latter the zoaria are smaller, the autozooecia reach the external surface at a broader angle, the cap-like structures are absent, and the autozooecial walls are thicker in the exozone.

Occurrence. - Hallopora elegantula is a species with a broad geographic distribution in the Upper Ordovician of Southern Europe and Scandinavia, as well as in the Lower

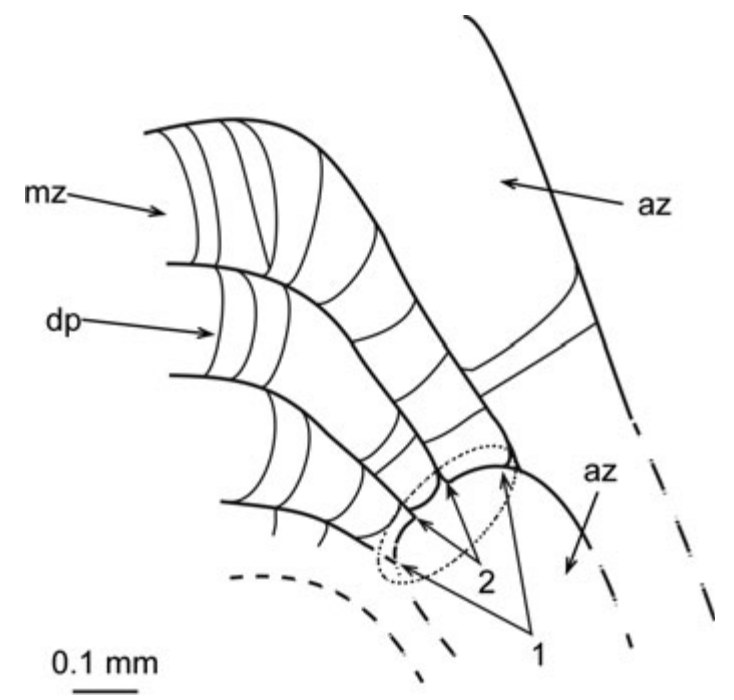

Figure 35. Hallopora elegantula (Hall, 1851). Schematic longitudinal section of the zoarium MPZ 2006/281 showing a cap-like structure (contained in the ellipse) in one autozooecium (az); numbers 1 and 2 show the outer and inner mesozoooecial $(\mathrm{mz})$ ring. The mesozooecia are densely tabulated by diaphragms (dp).

and Middle Silurian of North America. In the Mediterranean Region it has been identified in the Maciurru and Punta S'Argiola Member from the Domus-Novas Formation in Sardinia (Italy) (Conti 1990); in the carbonate and clastic sequence from the Montagne Noire (France) (Ernst \& Key 2007) both upper Katian in age; in La Peña Member (layers 1 and 2) in the Valdelaparra section (Fombuena, Zaragoza).

Hallopora cf. peculiaris (Pushkin, 1987)

Figures 36A-C, Table 18

cf. 1987 Hallopora peculiaris n. sp.; Pushkin, p. 153, pl. 8, fig. 5 , pl. 9 , fig. 1 .

cf. 1991a Hallopora peculiaris Pushkin, 1987. - Buttler, pp. 86-88, pl. 3, figs 3-8.

Table 17. Summary of the statistical analysis of Hallopora elegantula (Hall, 1851). Abbreviations as in Table 1.

\begin{tabular}{|c|c|c|c|c|c|}
\hline Character & Or & $X$ & DS & $\mathrm{Nm}$ & Nsp \\
\hline Autozooecial angle with zoarial surface & $43^{\circ}-85^{\circ}$ & $60^{\circ}$ & 11 & 15 & 2 \\
\hline Autozooecial diameter (in mm) & $0.21-0.45$ & 0.33 & 0.05 & 97 & 11 \\
\hline Autoooecial wall thickness in exozone (in mm) & $0.005-0.02$ & 0.011 & 0.004 & 74 & 10 \\
\hline Mesozooecial diameter (in mm) & $0.09-0.27$ & 0.16 & 0.04 & 92 & 11 \\
\hline Number of autozooecia per $2 \mathrm{~mm}$ & $2-4$ & 3.2 & 0.6 & 4 & 10 \\
\hline Number of mesozooecial diaphragms per $1 \mathrm{~mm}$ & $8-20$ & 14 & 3 & 63 & 10 \\
\hline Number of mesozooecia per $2 \mathrm{~mm}$ & $4.5-12$ & 7.3 & 2.3 & 4 & 10 \\
\hline Zoarial diameter (in mm) & $5-1.8$ & 3.4 & 1.1 & 11 & 11 \\
\hline
\end{tabular}


Table 18. Summary of the statistical analysis of Hallopora cf. peculiaris (Pushkin, 1987). Abbreviations as in Table 1.

\begin{tabular}{|c|c|c|c|c|c|}
\hline Character & Or & $\mathrm{X}$ & DS & $\mathrm{Nm}$ & Nsp \\
\hline Autozooecial angle with zoarial surface & $60^{\circ}-90^{\circ}$ & $83^{\circ}$ & 8 & 15 & 2 \\
\hline Autozooecial diameter (in mm) & $0.21-0.45$ & 0.34 & 0.05 & 31 & 1 \\
\hline Autoooecial wall thickness (in mm) & $0.005-0.01$ & 0.009 & 0.001 & 15 & 3 \\
\hline Cingulum thickness (in mm) & $0.025-0.12$ & 0.042 & 0.020 & 24 & 3 \\
\hline Mesozooecial large diameter (in mm) & $0.12-0.24$ & 0.18 & 0.04 & 24 & 1 \\
\hline Number of autozooecia per 1 square mm & $3-5.5$ & 4.2 & 1.2 & 4 & 1 \\
\hline Number of autozooecia per $2 \mathrm{~mm}$ & $0.5-4.5$ & 3 & 1 & 13 & 1 \\
\hline Number of mesozooecial diaphragms per $1 \mathrm{~mm}$ & $7-18$ & 13 & 3 & 11 & 3 \\
\hline Number of mesozooecia per 1 square mm & $13-16$ & 14.5 & 1.3 & 4 & 1 \\
\hline Number of mesozooecia per $2 \mathrm{~mm}$ & $2-7$ & 5 & 1.5 & 13 & 1 \\
\hline Zoarial diameter (in mm) & $3-5.5$ & 4 & 1.3 & 3 & 2 \\
\hline
\end{tabular}

Material. - One zoarium in tangential, longitudinal and transversal section (MPZ 2006/286); one zoarial fragment in longitudinal section (MPZ 2006/276); and one zoarial fragment in transversal section (MPZ 2006/277).

Description. - Zoarial growth habit branching with circular branches, $4.0 \mathrm{~mm}$ diameter on average. Autozooecia tubular, budding in the endozone with only slight inclination, but bending at the endozone-exozone boundary to reach the external zoarial surface at an average angle of $83^{\circ}$; autozooecia rarely budding from mesozooecia. Autozooecial apertures irregularly circular and without any specific arrangement pattern, $0.34 \mathrm{~mm}$ diameter on average, and with laminated cingulum, $0.042 \mathrm{~mm}$ thick; three autozooecia per $2 \mathrm{~mm}$ and 4.2 autozooecia per $1 \mathrm{~mm}^{2}$. Autozooecial diaphragms scarce in the endozone and inner exozone and absent in the outer exozone. Autozooecial cross section circular or subpolygonal in the endozone. Mesozooecial apertures irregular in shape, placed in gaps between autozooecia; mesozooecial large diameter $0.18 \mathrm{~mm}$ on average, with a frequency of $5 \mathrm{me}-$ sozooecia per $2 \mathrm{~mm}$ and 14.5 mesozooecia per $\mathrm{mm}^{2}$. Mesozooecia also present in the inner endozone, distinguishable from autozooecia by smaller diameter and more numerous diaphragms; mesozooecial diaphragms numerous, 13 per $\mathrm{mm}$ on average, increasing in number in the outer exozone, where cystoidal diaphragms are also present. Zooecial walls thin, $0.009 \mathrm{~mm}$ on average, with laminated microstructure parallel to the zooecial growth direction. Endozone and exozone well defined, with endozonal diameter twice the exozonal width.

Discussion. - According to Ernst \& Key's (2007) emended diagnosis the following characters allow this material to be included in the genus Hallopora: the branching growth habit of the zoarium; the well defined endozone and exozone; the distribution of autozooecia and mesozooecia; and the absence of acanthostyles.

The Iberian zoaria are similar to Hallopora peculiaris, a species well represented in the Upper Ordovician of Wales (Buttler 1991a). The Iberian material shares with it the broad angle made by the autozooecia at the external zoarial surface, the shape and size of autozooecial and mesozooecial apertures, the budding of mesozooecia also in the endozone, and the presence of a cingulum in the autozooecia. However, in the Iberian material the branch diameter is much smaller, the cingulum is thinner, and the autozooecial diaphragms are absent in the outer exozone. So, the Iberian material is only provisionally referred to Hallopora peculiaris until new material is found.

Hallopora cf. peculiaris can be distinguished from Hallopora elegantula, described above, because in the former the autozooecial tubes have a cingulum, the mesozooecia are also developed in the inner endozone, cap-like structures are absent, the autozooecial diaphragms are absent in the outer exozone and the mesozooecial cystoidal diaphragms are more numerous.

Occurrence. - The La Peña Member (layer 1), in the Valdelaparra section (Fombuena, Zaragoza).

\section{Genus Parvohallopora Singh, 1979}

Type species. - Monticulipora ramosa d'Orbigny, 1850. Lower Silurian of Cincinnati (Ohio, USA).

Discussion. - The genus Hallopora Bassler, 1911, include a group of morphologically heterogeneous species, with a wide age range (Middle Ordovician-Upper Silurian), characterized by the presence of diaphragms in the endozone and in the exozone, by the abundance of diaphragms in the inner endozone 

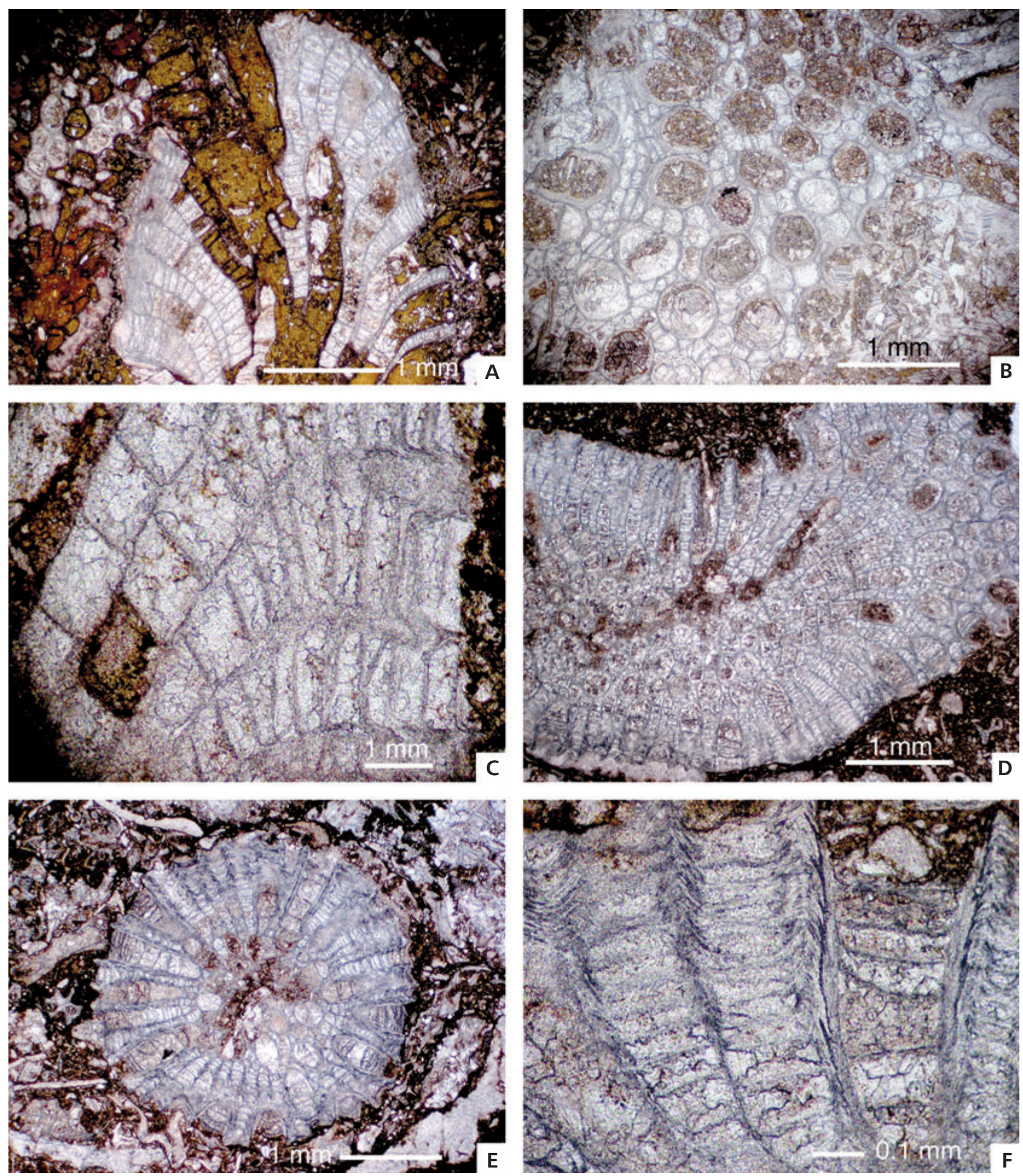

Figure 36. A-C - Hallopora cf. peculiaris (Pushkin, 1987). A, C - MPZ 2006/276; A - longitudinal section, C - detail of a mesozooecial group; B - MPZ 2006/286, transversal section. • D-F - Parvohallopora cf. ramosa (d'Orbigny, 1850). D - MPZ 2006/119, oblique section; E - MPZ 2006/121, transversal section; F-MPZ 2006/124, transversal section showing the wall units in the mesozooecia. A-C from the La Peña Member in the Valdelaparra section, D-F from the La Peña Member in the La Peña del Tormo section (Fombuena, Zaragoza).

and less abundance in the outer endozone, by the abundance of mesozooecia, by the circular autozooecial apertures, and by the absence of acanthostyles (Singh 1979).
Singh (1979) proposed segregating from this heterogeneous group the species displaying the following features: smaller autozooecial diameter, mural spines absent in the 
autozooecia, numerous, small mesozooecia between the autozooecia, cystoidal diaphragms rare to absent in autozooecia and absent in mesozooecia, and laminated zooecial walls with inverse $\mathrm{U}$ or $\mathrm{V}$ patterns which in Hallopora are rarely present. To accommodate these species Singh (1979) erected the genus Parvohallopora.

\section{Parvohallopora cf. ramosa (d'Orbigny, 1850)} Figures 36D-F, Table 19

cf. 1850 Monticulipora ramosa sp. nov.; d'Orbigny, p. 25. cf. 1979 Parvohallopora ramosa (d'Orbigny, 1850). - Singh, p. 228 , pl. 41, figs $1-3,4 a-c$, pl. 42 , figs 1,2 , 3a-c, pl. 43, figs 1a-c, 2, 3. Synonymies also included.

Material. - Four zoarial fragments in transversal section (MPZ 2006/121-124); one zoarial fragment in longitudinal section (MPZ 2006/120); and one zoarial fragment in oblique section (MPZ 2006/119).

Description. - Zoaria with branching growth habit, circular branches with $2.3 \mathrm{~mm}$ diameter on average. Autozooecia tubular, budding in the endozone with an inclination of $13^{\circ}$ on average; at the endozone-exozone boundary they suddenly bend to terminate at the external zoarial surface at an angle of $87^{\circ}$ on average; autozooecial apertures completely isolated by mesozooecia, circular in shape with $0.24 \mathrm{~mm}$ diameter on average and with a cingulum $0.017 \mathrm{~mm}$ thick on average; autozooecial cross section irregularly six-sided polygonal in the endozone. Autozooecia budding also at the endozone-exozone boundary. Autozooecial dia- phragms present in the endozone and exozone, with 9.5 diaphragms per $\mathrm{mm}$, and laminated microstructure with layers discontinuous with cingulum layers. Mesozooecia tubular, developing in the outer endozone and with the same inclination as autozooecia; mesozooecial apertures subcircular or four-sided polygonal, $0.11 \mathrm{~mm}$ diameter on average, isolating autozooecia or in small groups forming maculae; mesozooecia densely tabulated by diaphragms, 22.5 per $\mathrm{mm}$; diaphragms with laminated microstructure, with clear wall units continuing through adjacent mesozooecia and terminating at the mesozooecial-autozooecial boundary. Zooecial walls laminated with an inverse $\mathrm{V}$ pattern; laminae concentrically arranged around autozooecial and mesozooecial apertures in the exozone; autozooecial walls $0.024 \mathrm{~mm}$ thick and mesozooecial walls $0.017 \mathrm{~mm}$ thick in the exozone, but in the endozone $0.009 \mathrm{~mm}$ thick and $0.008 \mathrm{~mm}$ thick, respectively. Endozone and exozone well defined, but with the exozone more developed than the endozone $(0.70 \mathrm{~mm}$ thick exozone vs. $1.04 \mathrm{~mm}$ diameter endozone).

Discussion. - According to Singh's (1979) diagnosis: the presence of a large exozone, the zooecial angle with respect to the zoarial surface, the shape of autozooecia in the endozone and exozone, the wall units in mesozooecial diaphragms, the inverse $\mathrm{V}$ laminated pattern of the zooecial walls, the presence of autozooecial and mesozooecial diaphragms, both in the endozone and exozone, the abundance, shape and size of mesozooecia, and the high density of diaphragms, are the characters which allow this material to be included in the genus Parvohallopora.

The Iberian material is similar to Parvohallopora

Table 19. Summary of the statistical analysis of Parvohallopora cf. ramosa (d'Orbigny, 1850). Abbreviations as in Table 1.

\begin{tabular}{|c|c|c|c|c|c|}
\hline Character & Or & $\mathrm{X}$ & DS & $\mathrm{Nm}$ & Nsp \\
\hline Autozooecial angle with zoarial surface & $83^{\circ}-90^{\circ}$ & $87^{\circ}$ & 4 & 3 & 1 \\
\hline Autozooecial angle in endozone & $20^{\circ}-8^{\circ}$ & $13^{\circ}$ & 5 & 5 & 2 \\
\hline Autozooecial diameter (in mm) & $0.19-0.27$ & 0.24 & 0.02 & 19 & 2 \\
\hline Autozooecial wall thicknes in endozone (in mm) & $0.005-0.02$ & 0.009 & 0.004 & 19 & 4 \\
\hline Autoooecial wall thickness in exozone (in mm) & $0.01-0.04$ & 0.024 & 0.008 & 17 & 2 \\
\hline Cingulum thickness (in mm) & $0.01-0.025$ & 0.017 & 0.004 & 20 & 6 \\
\hline Endozone diameter (in mm) & $0.9-1.44$ & 1.04 & 0.2 & 6 & 6 \\
\hline Exozone thickness (in mm) & $0.48-1.05$ & 0.7 & 0.15 & 25 & 6 \\
\hline Mesozooecial diameter (in mm) & $0.05-0.16$ & 0.11 & 0.03 & 15 & 2 \\
\hline Mesozooecial wall thickness in endozone (in mm) & $0.005-0.01$ & 0.008 & 0.003 & 13 & 2 \\
\hline Mesozooecial wall thickness in exozone (in mm) & $0.005-0.03$ & 0.017 & 0.008 & 13 & 2 \\
\hline Number of autozooecial diaphragms per mm & $2-18$ & 9.5 & 4.1 & 31 & 5 \\
\hline Number of mesozooecial diaphragms per $1 \mathrm{~mm}$ & $13.5-30$ & 22.5 & 4.4 & 42 & 6 \\
\hline Zoarial diameter (in mm) & $1.7-2.5$ & 2.3 & 0.5 & 7 & 6 \\
\hline
\end{tabular}


Table 20. Summary of the statistical analysis of Heterotrypa sp. Abbreviations as in Table 1.

\begin{tabular}{|c|c|c|c|c|c|}
\hline Character & Or & $\mathrm{X}$ & DS & $\mathrm{Nm}$ & Nsp \\
\hline Acanthostyles diameter (in mm) & $0.04-0.2$ & 0.11 & 0.03 & 39 & 1 \\
\hline Autozooecial angle with zoarial surface & $72^{\circ}-82^{\circ}$ & $77^{\circ}$ & 3 & 11 & 1 \\
\hline Autozooecial diameter (in mm) & $0.18-0.28$ & 0.24 & 0.03 & 17 & 1 \\
\hline Autozooecial wall thicknes in endozone (in mm) & $0.005-0.02$ & 0.01 & 0.005 & 13 & 1 \\
\hline Autoooecial wall thickness in exozone (in mm) & $0.035-0.08$ & 0.05 & 0.015 & 13 & 1 \\
\hline Endozone diameter (in mm) & $1.29-1.71$ & 1.47 & 0.16 & 5 & 1 \\
\hline Exozone thickness (in mm) & $0.51-0.81$ & 0.7 & 0.14 & 6 & 1 \\
\hline Mesozooecial diameter (in mm) & $0.07-0.13$ & 0.1 & 0.02 & 16 & 1 \\
\hline Number of acanthostyles per $1 \mathrm{~mm}$ & $1-3$ & 1.7 & 0.9 & 10 & 1 \\
\hline Number of acanthostyles per 1 square mm & $9-14$ & 12 & 3 & 3 & 1 \\
\hline Number of autozooecia per $1 \mathrm{~mm}$ & $1.5-3$ & 2.2 & 0.5 & 10 & 1 \\
\hline Number of autozooecia per 1 square $\mathrm{mm}$ & $9.5-10$ & 9.8 & 0.3 & 3 & 1 \\
\hline Number of autozooecial diaphragms per mm & $1-7$ & 4 & 2 & 8 & 1 \\
\hline Number of mesozooecial diaphragms per $1 \mathrm{~mm}$ & $2-12$ & 7 & 4 & 6 & 1 \\
\hline Number of mesozooecia per $1 \mathrm{~mm}$ & $0-2$ & 0.4 & 0.9 & 10 & 1 \\
\hline Number of mesozooecia per 1 square mm & $0-3$ & 2 & 2 & 3 & 1 \\
\hline Zoarial diameter (in mm) & $2.7-3.3$ & 3 & 0.2 & 5 & 1 \\
\hline
\end{tabular}

ramosa (d'Orbigny, 1850), widely distributed during the Upper Ordovician in the palaeocontinents of Baltica and Laurentia. In addition to the diagnostic characters of the genus, both share the following features: the development of autozooecia at the endozone-exozone boundary, the presence of diaphragms throughout the endonoze and exozone, as well as the high density of diaphragms in the exozone, and the presence of a cingulum in the autozooecia. But the zoarial surface of Parvohallopora ramosa is completely covered by monticules. These monticules vary from conical protuberances to rings completely encircling the branches. In the Iberian material there is no evidences of such structures, and in spite of the few available zoaria, these structures are of sufficient size to have been visible in some of the studied sections. So, the Iberian material is only provisionally referred to Parvohallopora ramosa.

Occurrence. - The La Peña Member in the La Peña del Tormo section (Fombuena, Zaragoza).

Family Heterotrypidae Ulrich, 1890

\section{Genus Heterotrypa Nicholson, 1879}

Type species. - Monticulipora frondosa d'Orbigny, 1850. Upper Ordovician of USA.

\section{Heterotrypa sp.}

Figures 37A-C, 38, Table 20

Material. - One zoarium (MPZ 2006/111) in tangential, longitudinal, transversal and oblique section.

Description. - Zoaria with branching growth habit, branch cross section being circular, $3 \mathrm{~mm}$ diameter on average. Autozooecial apertures circular, with $0.24 \mathrm{~mm}$ diameter on average, frequently modified by extremely abundant acanthostyles so that they acquire petal shape due to the inclusion of large acanthostyles in their walls; 2.2 autozooecial apertures per $\mathrm{mm}$ and 9.8 autozooecial apertures per $\mathrm{mm}^{2}$. Autozooecia tubular, budding in the endozone and developing parallel to branch growth direction up to the outer endozone where they slightly bend; in the inner exozone they strongly bend to reach the external zoarial surface at an angle of $77^{\circ}$ on average; some autozooecia develop at the endozone-exozone boundary. Autozooecial diaphragms present in the exozone, 4 diaphragms per mm on average, but almost absent in the endozone. Mesozooecial apertures subcircular or irregularly polygonal, with $0.10 \mathrm{~mm}$ diameter on average; mesozooecia scarce, 0.4 per $\mathrm{mm}$ and 2.0 per $\mathrm{mm}^{2}$, on average. Wedge shaped mesozooecia developed in the outer endozone, with 7 diaphragms per mm. Mesozooecial diaphragms with walls units. Acanthostyles characterized by a large diameter, $0.11 \mathrm{~mm}$ on average (with a range of 
0.04-0.20 mm), composed of a large central lumen of hyaline calcite and dark laminae concentrically arranged around the lumen; most acanthostyles develop at the endozone-exozone boundary, but some of them develop in the inner endozone parallel to autozooecia; four or five acanthostyles around each autozooecial aperture, 1.7 per $\mathrm{mm}$ and 12.0 per $\mathrm{mm}^{2}$. Autozooecial walls laminated with laminae altered by acanthostyles; with a thickness of $0.05 \mathrm{~mm}$ in the exozone and $0.01 \mathrm{~mm}$ in the endozone, on average, wavy and with nodular thickenings. Endozone and exozone well defined, with an average diameter of $1.47 \mathrm{~mm}$ and an average width of $0.70 \mathrm{~mm}$, respectively.

Discussion. - According to Ernst \& Key's (2007) emended diagnosis of the genus Heterotrypa Nicholson, 1879, the following characters have allowed this zorium to be included in Heterotrypa: the zoarial growth habit, the endozonal walls with nodular thickenings, the distribution of autozooecial and mesozooecial diaphragms, the wedge shape of the mesozooecia, and the presence of acanthostyles in both the exozone and the endozone.

The large diameter of the acanthostyles and the distortion that they produce in the autozooecial apertures are characters not described before in other Heterotrypa species. However, since there is only one zoarium here and it is not possible to study the external surface, it cannot be assigned to a precise species.

Along the Mediterranean margin of Gondwana Heterotrypa magnopora Boulange, 1963, has been previously identified and described by Ernst \& Key (2007) from the upper Katian of the Montagne Noire (France). The Iberian Heterotrypa shares with it the absence of autozooecial diaphragms in the endozone and also the low number of mesozooecia, plus the fact that mesozooecia are only present in the exozone. But they can be distinguished because in Heterotrypa magnopora the autozooecia reach the external zoarial surface at an angle of $90^{\circ}$ while in the presently studied zoarium it is at an angle of $77^{\circ}$, and the acanthostyles are much smaller.

The Iberian Heterotrypa in similar to Heterotrypa sladei Buttler, 1991, described by Buttler (1991a) in the Upper Ordovician of Wales. But they can also be distinguished because in the Welsh species autozooecial diaphragms develop in both the endozone and the exozone, the mesozooecia are also present in endozone and are abundant, and the acanthostyles are smaller than in the Iberian species.

Occurrence. - The La Peña Member (layer 1) in the Valdelaparra section (Fombuena, Zaragoza).

Family Monticuliporidae

\section{Genus Homotrypa Ulrich, 1882}

Type species. - Homotrypa curvata Ulrich, 1882. Upper Ordovician (Ashgill) of North America.

\section{Homotrypa sp.}

Figures 39E, Table 21

Material. - One zoarial fragment in tangential section (MPZ 2006/196); and one zoarial fragment in transversal and oblique section (MPZ 2006/197).

Table 21. Summary of the statistical analysis of Homotrypa sp. Abbreviations as in Table 1.

\begin{tabular}{|c|c|c|c|c|c|}
\hline Character & Or & $\mathrm{X}$ & DS & $\mathrm{Nm}$ & Nsp \\
\hline Autozooecial angle with zoarial surface & $22^{\circ}-72^{\circ}$ & $42^{\circ}$ & 17 & 9 & 2 \\
\hline Autozooecial large diameter (in mm) & $0.3-0.45$ & 0.36 & 0.05 & 8 & 1 \\
\hline Autozooecial small diameter (in mm) & $0.17-0.27$ & 0.22 & 0.03 & 8 & 1 \\
\hline Autozooecial wall thicknes in endozone (in mm) & $0.005-0.015$ & 0.009 & 0.003 & 24 & 2 \\
\hline Autoooecial wall thickness in exozone (in mm) & $0.025-0.04$ & 0.033 & 0.006 & 8 & 2 \\
\hline Endozonal diameter & $1.2-2.2$ & 1.7 & 0.4 & 6 & 2 \\
\hline Exozona thickness (in mm) & $0.39-0.66$ & 0.5 & 0.08 & 15 & 2 \\
\hline Mesozooecial diameter (in mm) & $0.05-0.15$ & 0.11 & 0.04 & 5 & 1 \\
\hline Number of autozooecia per $1 \mathrm{~mm}$ & $3-6$ & 4.2 & 0.9 & 17 & 2 \\
\hline Number of autozooecia per 1 square mm & $15-18$ & 16.7 & 1.2 & 5 & 2 \\
\hline Number of autozooecial cystiphragms per mm & $10-17$ & 13 & 3 & 3 & 1 \\
\hline Number of autozooecial diaphragms per mm & $7-12$ & 11 & 3 & 8 & 2 \\
\hline Number of mesozooecial diaphragms per mm & $10-20$ & 15 & 7 & 2 & 1 \\
\hline Zoarial diameter (in mm) & $2.67-3.3$ & 2.93 & 0.21 & 7 & 2 \\
\hline
\end{tabular}



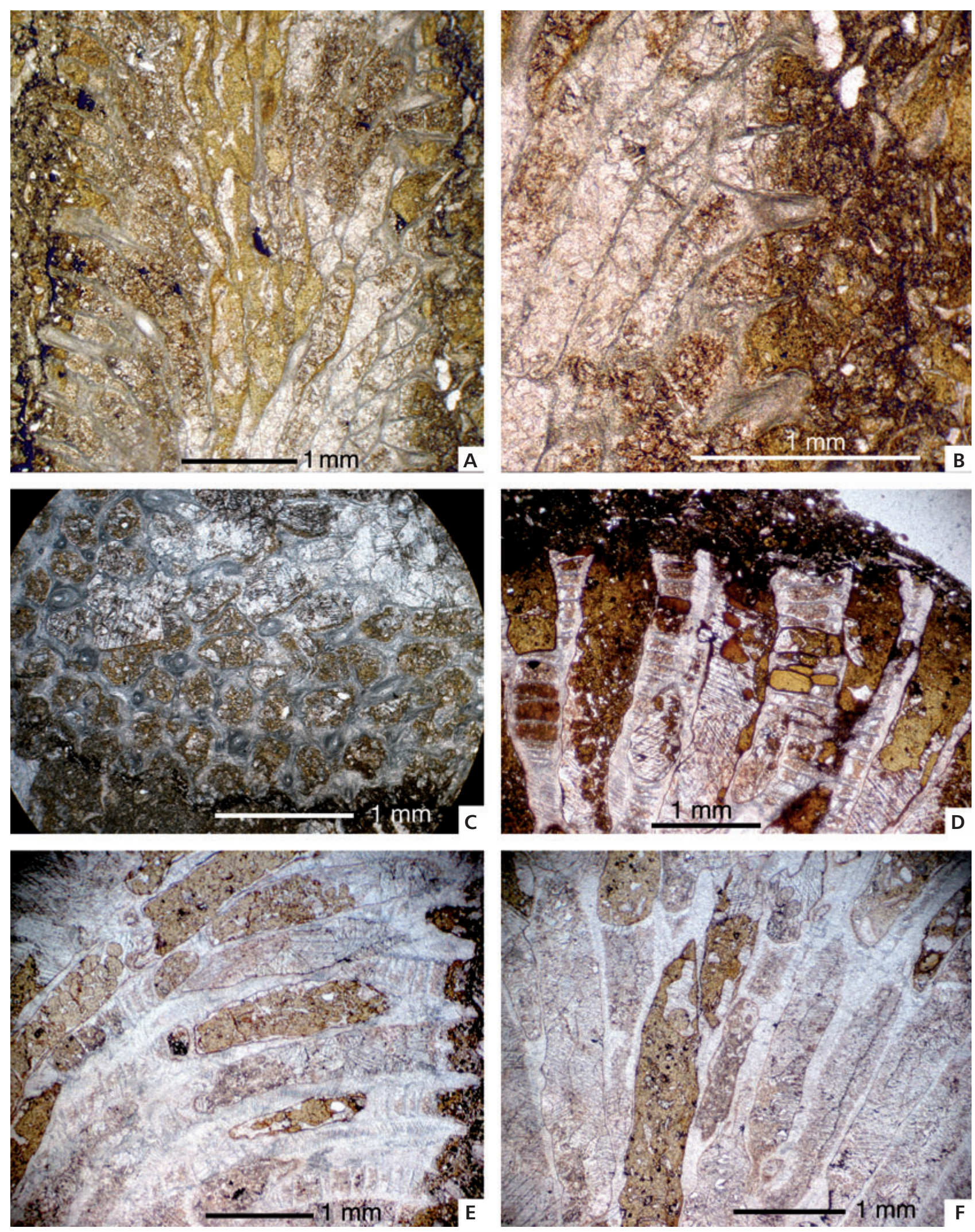

Figure 37. A-C - Heterotrypa sp., MPZ 2006/111; A - longitudinal section; B - detail of the longitudinal section; C - tangential section. - D-F - Dybowskites ernsti sp. nov. D - MPZ 2006/289 (holotype), transversal section; E, F - MPZ 2006/288, longitudinal sections. All specimens from the La Peña Member in the Valdelaparra section (Fombuena, Zaragoza). 


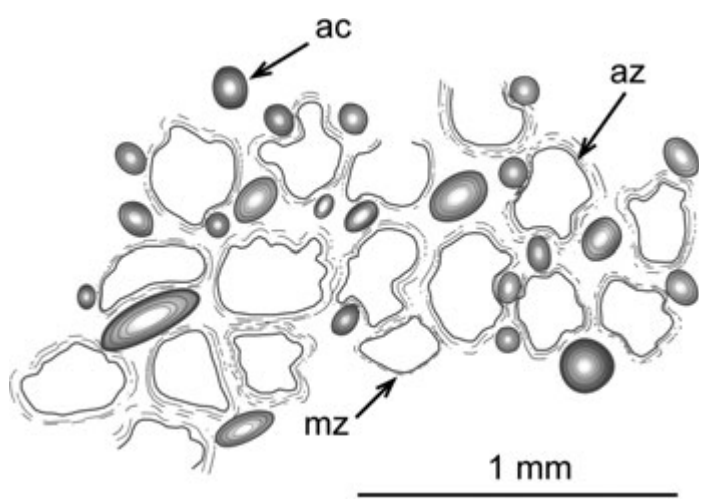

Figure 38. Heterotrypa sp. Schematic tangential section showing the large acanthostyles (ac) modifying autozooecial apertures (az), and the irregular mesozooecial sections $(\mathrm{mz})$.

Description. - Zoarial growth habit branching, branches with circular cross section, $2.93 \mathrm{~mm}$ diameter on average. Autozooecial apertures elongated polygonal, with five or six sides, with the long axis parallel to branch growth direction; large diameter $0.36 \mathrm{~mm}$ and small diameter $0.22 \mathrm{~mm}$, on average, and 4.2 autozooecia per $\mathrm{mm}$ and 16.7 autozooecia per $\mathrm{mm}^{2}$; autozooecia tubular, budding in the axial zone, parallel to the growth direction of the branch in the inner endozone, but narrowing and bending slightly in the outer endozone to reach the external zoarial surface at an average angle of $42^{\circ}$. Endozone-exozone boundary marked by budding of new autozooecia and development of autozooecial cystiphragms on one side of their walls; 13 autozooecial cystiphragms per $\mathrm{mm}$ on average. Autozooecial diaphragms absent or scarce in the inner endozone and numerous in the outer endozone and exozone ( 7 to 12 diaphragms per mm), some of them with cystiphragms joined to the opposite wall. Mesozooecia with apertures irregularly polygonal, with an average diameter of $0.11 \mathrm{~mm}$, developing in the outer exozone; mesozooecia scarce (less than one per $\mathrm{mm}^{2}$ ), wedge shaped and densely tabulated by diaphragms, averaging 15 diaphragms per mm. Autozooecial wall microstructure lost due to diagenesis, $0.033 \mathrm{~mm}$ thick in the exozone and $0.009 \mathrm{~mm}$ thick in the endozone, on average. Small structures similar to acanthostyles thickening autozooecial walls in the exozone. Endozone and exozone well defined, but the endozone being larger than the exozone ( $1.7 \mathrm{~mm}$ diameter on average in the endozone and average width $0.5 \mathrm{~mm}$ in the exozone).

Discussion. - The characters which allow these zoaria to be included in the genus Homotrypa, following Ernst \& Key's (2007) diagnosis, are: the zoarial branching growth habit, the polygonal autozooecial cross section, the presence of cystiphragms only in the outer exozone, more numerous diaphragms in the exozone, the presence of mesozooecia and acanthostyles, and the thickness of zooecial walls both in the endozone and the exozone.
Homotrypa sp. is similar to Homotrypa oweni Ross, 1965, but they can be distinguished because the latter has less autozooecial diaphragms but more numerous mesozooecia.

In the Mediterranean Province (Jiménez-Sánchez \& Villas in press) Homotrypa miqueli (Prantl, 1940) has been described from the upper Katian of the Montagne Noire (France) [Ernst \& Key (2007)]. Homotrypa sp. can be distinguished from Homotrypa miqueli because the former has slimmer zoaria, diaphragms both in the endozone and exozone, and abundant mesozooecial diaphragms.

Occurrence. - La Peña Member (layer 1), in the Valdelaparra section (Fombuena, Zaragoza).

Family Ralfimartitidae Gorjunova, 2005

\section{Genus Dybowskites Pushkin, 1987}

Type species. - Lioclemella clava Bassler, 1911. Jewe Shale (Baron toll), in Kegel' beds (Habbinem), and in Wassalem's beds (Uxnorm); Upper Ordovician of Estonia.

\section{Dybowskites ernsti sp. nov.}

Figures 37D-F, 39A, 40, 41, Table 22

Holotype. - MPZ 2006/289.

Paratypes. - MPZ 2006/288.

Type horizon. - La Peña Member of the Cystoid Limestone Formation, Upper Ordovician.

Type locality. - The Valdelaparra section (Fombuena, Zaragoza).

Material. - Two zoaria in tangential, longitudinal and transversal section (MPZ 2006/288, 289).

Etymology. - After Andrej Ernst thanking him for his help with my doctoral thesis.

Diagnosis. - Dybowskites characterized by the large size of the autozooecial and mesozooecial apertures, as well as by its large acanthostyles.

Description. - Zoaria with branching growth habit, branches circular in cross section, $13 \mathrm{~mm}$ diameter on average, and dichotomously divided. Autozooecial apertures circular or subpolygonal, $0.49 \mathrm{~mm}$ diameter on average and without any apparent arrangement on the zoarial external surface; autozooecial apertures at a frequency of 2.5 per $2 \mathrm{~mm}$ and 2.7 per $\mathrm{mm}^{2}$, on average. Autozooecia tubular, bud- 

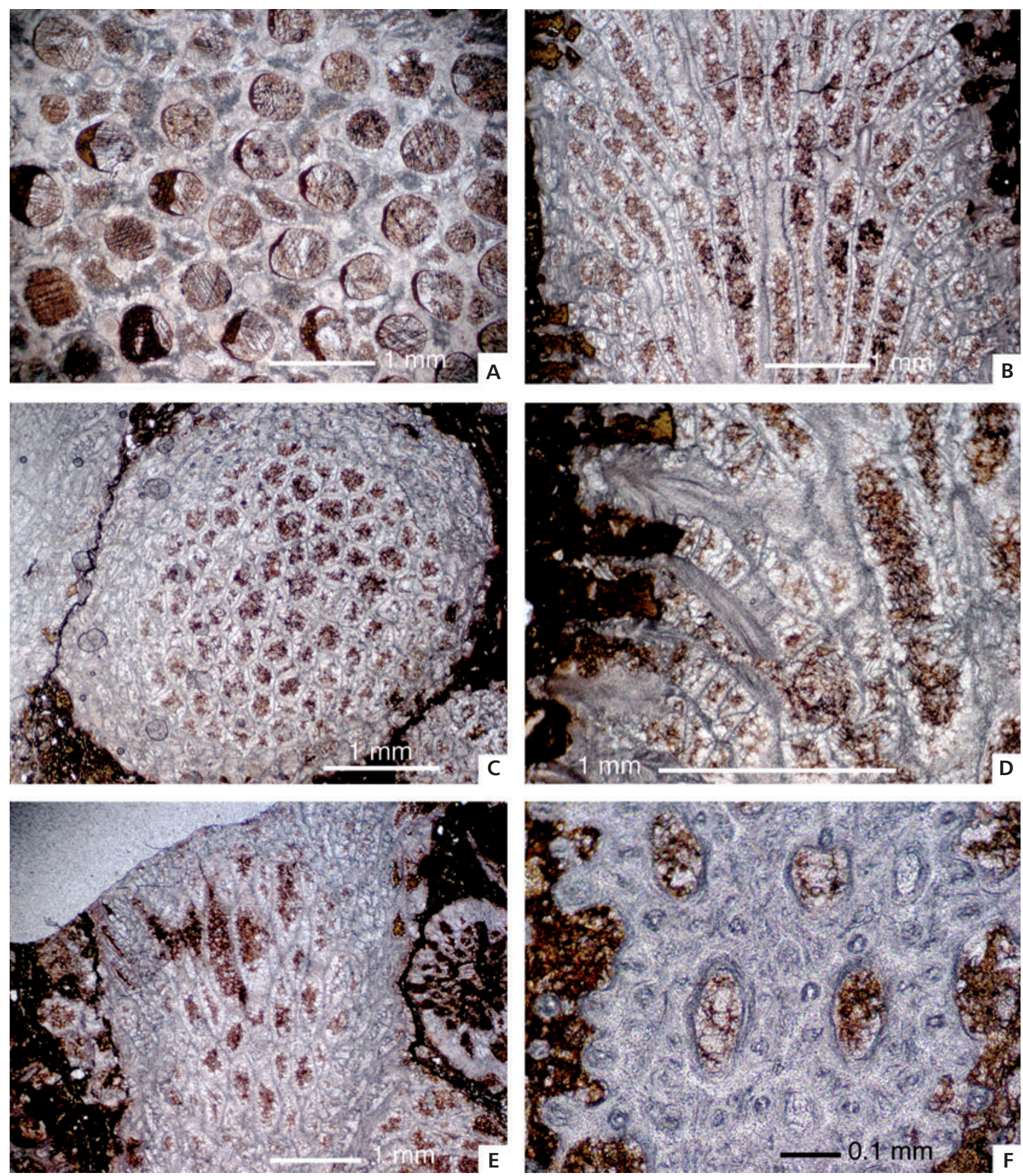

Figure 39. A - Dybowskites ernsti sp. nov., MPZ 2006/289 (holotype), transversal section. • B-D - Eridotrypa obliqua Conti, 1990 , MPZ 2006/188. B - longitudinal section; C - transversal section; D - detail of the longitudinal section. • E - Homotrypa sp., MPZ 2006/197, longitudinal section. - F - Trematopora acanthostylita sp. nov., MPZ 2006/165, tangential section. A-E from the La Peña Member in the Valdelaparra section, F from the La Peña Member in the La Peña del Tormo section.

ding in the endozone, parallel to the branch growth direction; in the outer endozone they bend slightly up towards the endozone-exozone boundary where they strongly bend to reach the zoarial external surface at an angle of almost $90^{\circ}$. Autozooecial diaphragms frequent in the endozone, reduced to one or two in the exozone. Mesozooecial aper- 


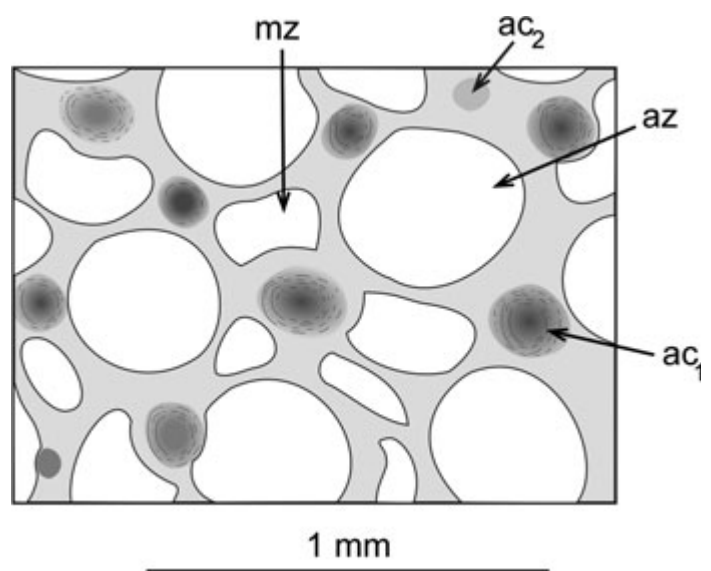

Figure 40. Dybowskites ernsti sp. nov. Schematic tangential section of the zoarium MPZ 2006/289 showing large autozooecia (az), irregular mesozooecia (mz), and the two types of acanthostyles: the larger ones with laminated microstructure $\left(\mathrm{ac}_{1}\right)$ and the smaller ones with massive microstructure $\left(\mathrm{ac}_{2}\right)$.

tures irregular in shape due to large acanthostyles, with a large diameter of $0.25 \mathrm{~mm}$ on average; mesozooecia scarce, 1.4 per $2 \mathrm{~mm}$ and 2.1 per $\mathrm{mm}^{2}$, on average. Mesozooecia developed at the endozone-exozone boundary, wedge-shaped in its proximal part and tubular in its distal part; mesozooecial tubes sometimes narrowed due to acanthostyles; mesozooecial diaphragms abundant, 9 per mm, and varied in shape. Two types of acanthostyles: the largest ones composed of a large dark lumen with laminae concentrically arranged around it, larger than some mesozooecia in cross section and developed close to them; smaller acanthostyles with massive microstructure, commonly protruding above the external zoarial surface. Considering both types of acanthostyle, they range from $0.13 \mathrm{~mm}$ to

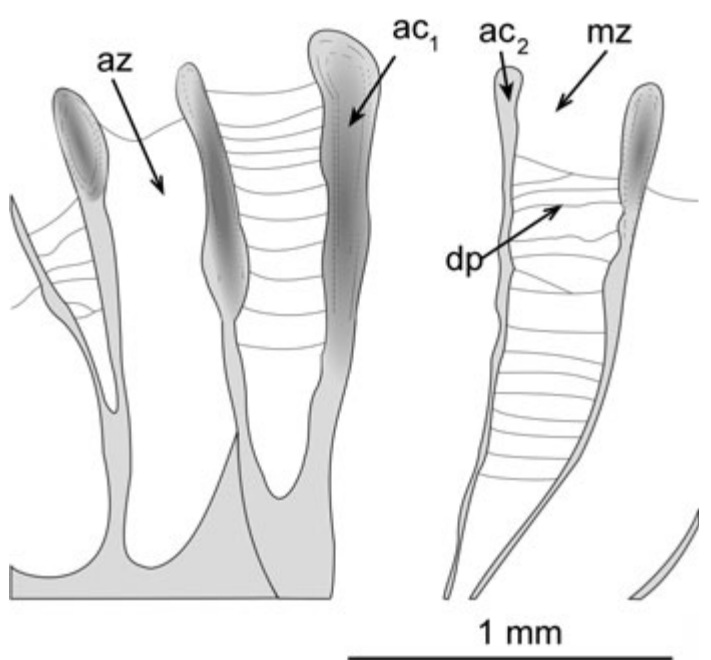

Figure 41. Dybowskites ernsti sp. nov. Schematic transversal section of the zoarium MPZ 2006/289 showing autozooecia (az), mesozooecia (mz) densely tabulated by diaphragms (dp), and the two types of acanthostyles $\left(\mathrm{ac}_{1}\right.$ and $\left.\mathrm{ac}_{2}\right)$

$0.30 \mathrm{~mm}$, with $0.21 \mathrm{~mm}$ diameter on average; 2 acanthostyles per $2 \mathrm{~mm}$ and 4 per $\mathrm{mm}^{2}$. Autozooecial walls laminated, $0.051 \mathrm{~mm}$ thick on average in the exozone and $0.019 \mathrm{~mm}$ thick on average in the endozone.

Discussion. - According to Ernst \& Key's (2007) emended diagnosis the following characters allow this Iberian material to be included in the genus Dybowskites: the branching growth habit, the shape of the autozooecia and the mesozooecia, their budding pattern, the distribution of autozooecial and mesozooecial diaphragms, as well as the presence of two types of acanthostyles.

The presence of autozooecia, mesozooecia and

Table 22. Summary of the statistical analysis of Dybowskites ernsti sp. nov. Abbreviations as in Table 1.

\begin{tabular}{|c|c|c|c|c|c|}
\hline Character & Or & $\mathrm{X}$ & DS & $\mathrm{Nm}$ & Nsp \\
\hline Acanthostyles diameter (in mm) & $0.13-0.3$ & 0.21 & 0.07 & 38 & 2 \\
\hline Autozooecial diameter (in mm) & $0.36-0.6$ & 0.49 & 0.06 & 47 & 2 \\
\hline Autozooecial wall thicknes in endozone (in mm) & $0.01-0.03$ & 0.019 & 0.005 & 20 & 2 \\
\hline Autoooecial wall thickness in exozone (in mm) & $0.02-0.06$ & 0.051 & 0.01 & 13 & 2 \\
\hline Mesozooecial large diameter (in mm) & $0.18-0.36$ & 0.25 & 0.05 & 26 & 2 \\
\hline Number of acanthostyles per 1 square mm & $2-6$ & 4 & 1 & 21 & 2 \\
\hline Number of acanthostyles per $2 \mathrm{~mm}$ & $0-4$ & 2 & 1.2 & 12 & 2 \\
\hline Number of autozooecia per 1 square mm & $2-4.5$ & 2.7 & 0.6 & 21 & 2 \\
\hline Number of autozooecia per $2 \mathrm{~mm}$ & $0.5-2.5$ & 2.5 & 0.9 & 12 & 2 \\
\hline Number of mesozooecial diaphragms per $1 \mathrm{~mm}$ & $6-13$ & 9 & 2 & 15 & 2 \\
\hline Number of mesozooecia per 1 square mm & $0-4$ & 2.1 & 1.7 & 21 & 2 \\
\hline Number of mesozooecia per $2 \mathrm{~mm}$ & $0-3$ & 1.4 & 1 & 12 & 2 \\
\hline Zoarial diameter (in mm) & $10-15$ & 13 & 2 & 4 & 2 \\
\hline
\end{tabular}


acanthostyles with a larger diameter than those present in other species of Dybowskites, even in those with larger branch diameter, prevent assigning these zoaria to any of the known species. So, Dybowskites ernsti sp. nov. is defined to include in it this Iberian material.

Dybowskytes orbicularis (Modzalevskaya, 1953) was previously described from the upper Katian of the Montagne Noire (Ernst \& Key 2007). Dybowskites ernsti sp. nov. and Dybowskytes orbicularis can be distinguished because the former has less mesozooecia and acanthoslyles with respect to autozooecia (a relationship slightly greater than $1: 1$ between autozooecia and mesozooecia in the new species vs. a relationship of almost 1:3 in Dybowskytes orbicularis; and of 2 to 6 acanthostyles per $\mathrm{mm}^{2}$ in the new species vs. 5 to 8 acanthostyles in the French species). The mesozooecial shape in cross sections is also different in both species (irregular in the Iberian species and polygonal in the French species). Additionally, the number of mesozooecial diaphragms per $\mathrm{mm}$ is higher in the French species.

Dybowskites ernsti sp. nov. can be distinguished from Dybowskites clavus (Bassler, 1911) described by Gorjunova (2005) and from Dybowskites hispidus Gorjunova, 2005 , because these two have branches with smaller diameter and thinner autozooecial walls than the Iberian species. It can be also distinguished from Dybowskites clavus because in the latter the mesozooecial apertures are strongly distorted by the acanthostyles, while in the Iberian material there is much less distortion; and it can also be distinguished from Dybowskites hispidus because in the latter the autozooecia have several hemiphragms in the endozone that are absent in Dybowskites ernsti sp. nov.

Occurrence. - This species is known exclusively from its type locality: the La Peña Member (layer 1) in the Valdelaparra section (Fombuena, Zaragoza).
Family Trematoporidae Miller, 1889

\section{Genus Eridotrypa Ulrich, 1893}

Type species. - Eridotrypa mutabilis Ulrich, 1893. Galena Shales, Upper Ordovician of Minnesota; Trenton Group, Upper Ordovician of Kentucky; Middle and Upper Ordovician of Iowa and Wisconsin (USA).

Discussion. - Ulrich (1893) included the new genus Eridotrypa in the family Batostomellidae. Ross (1967b) emended the diagnosis of Eridotrypa and assigned it to the family Aisenvergiidae, based on the constriction in the autozooecial tubes at the endozone-exozone boundary. McKinney (1971) assigned Eridotrypa to the family Trematoporidae following the Russian school (e.g., Astrova 1965), and suggesting that the constriction of the autozooecial wall in the inner exozone is a convergent character and, thus, it does not indicate any phylogenetic relationship between taxa. Conti (1990) considered that Eridotrypa is closely related to the genus Batostomella Ulrich, 1882, and Bythopora Miller \& Dyer, 1878, because they share the same astogenetic pattern (McKinney 1977) as well as the appearance of the autozooecial walls, and therefore included Eridotrypa in the family Batostomellidae as Ulrich (1893) did originally. It is not clear what is the phylogenetic significance of the astogenetic pattern, since one specimen can have more than one; so I follow McKenney's (1971) proposal and Eridotrypa is assigned here to the family Trematoporidae.

\section{Eridotrypa obliqua Conti, 1990}

Figures 39B-D, 42, Table 23

1990 Eridotrypa obliqua n. sp.; Conti, p. 106, pl. 14, figs 5-8.

Table 23. Summary of the statistical analysis of Eridotrypa obliqua Conti, 1990. Abbreviations as in Table 1.

\begin{tabular}{|c|c|c|c|c|c|}
\hline Character & Or & $\mathrm{X}$ & DS & $\mathrm{Nm}$ & Nsp \\
\hline Acanthostyles diameter (in mm) & $0.04-0.15$ & 0.09 & 0.03 & 26 & 1 \\
\hline Autozooecial angle with zoarial surface in adult zone of colony & $85^{\circ}-90^{\circ}$ & $89^{\circ}$ & 2 & 8 & 1 \\
\hline Autozooecial angle with zoarial surface in young zone of colony & $46^{\circ}-68^{\circ}$ & $58^{\circ}$ & 11 & 3 & 1 \\
\hline Autozooecial large diameter (in mm) & $0.28-0.5$ & 0.39 & 0.08 & 10 & 1 \\
\hline Autozooecial small diameter (in mm) & $0.17-0.3$ & 0.23 & 0.04 & 13 & 1 \\
\hline Autozooecial wall thicknes in endozone (in mm) & $0.005-0.02$ & 0.015 & 0.013 & 20 & 1 \\
\hline Autoooecial wall thickness in exozone (in mm) & $0.03-0.08$ & 0.05 & 0.01 & 17 & 1 \\
\hline Endozonal diameter & $1.65-2.7$ & 2.2 & 0.4 & 5 & 1 \\
\hline Exozona thickness (in mm) & $0.36-0.9$ & 0.6 & 0.15 & 12 & 1 \\
\hline Mesozooecial diameter (in mm) & $0.04-0.09$ & 0.07 & 0.02 & 4 & 1 \\
\hline Number of autozooecial diaphragms per mm & $5-11$ & 8 & 3 & 9 & 1 \\
\hline Zoarial diameter (in mm) & $2.8-4.2$ & 3.6 & 0.5 & 6 & 1 \\
\hline
\end{tabular}




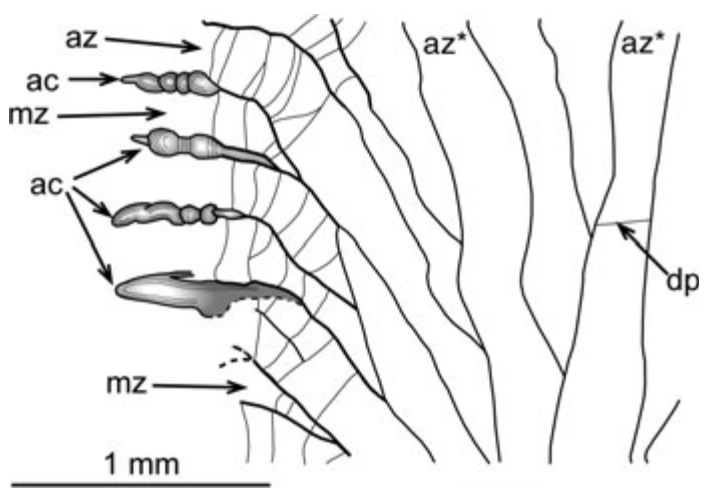

Figure 42. Eridotrypa obliqua Conti, 1990. Schematic longitudinal section showing autozooecia budding in the axial zone (az*), with occasional diaphragms (dp), and autozooecia developed in the inner exozone (az), small mesozooecia (mz), and "moniliform" acanthostyles (ac).

2007 Eridotrypa sp.; Jiménez-Sánchez et al., fig. 7 (3, 4).

Material. - One zoarium in longitudinal, transversal and oblique section (MPZ 2006/188).

Description. - Zoarial growth habit branching with branches circular in cross section, $3.6 \mathrm{~mm}$ diameter on average and with overgrown surfaces. Autozooecial apertures oval or elongate polygonal with the large diameter being parallel to the branch growth direction, $0.39 \mathrm{~mm}$ on average, and small diameter $0.23 \mathrm{~mm}$ on average; autozooecia budding in the endozone with two size ranges: the most numerous are those with the larger diameter $(0.18-0.50 \mathrm{~mm}$, measurements from longitudinal section), and developed parallel to the axial zone, the second type having a smaller diameter (0.17-0.30 mm, measurements from longitudinal section); both types of autozooecia gently bending and their diameter slightly decreasing in the outer endozone; autozooecia reach the external zoarial surface at the same inclination as in the endozone ( $58^{\circ}$ on average) in the young zoarial zones; in the old zone of the zoarium, autozooecia suddenly bend at the endozone-exozone boundary to reach the zoarial external surface at an average angle of $89^{\circ}$. Autozooecial diaphragms absent or scarce in the endozone and outer exozone, but abundant in the inner exozone, with 8 diaphragms per mm on average; autozooecial cross section hexagonal or four-sided polygonal in the inner endozone, with two size ranges of diameter; autozooecia homogeneous in size in the outer endozone. Mesozooecial apertures three or four sided polygonal with an average diameter of $0.07 \mathrm{~mm}$; mesozooecia scarce, developed in the outer exozone as small wedges and with diaphragms separated by a distance equal to one mesozooecial diameter. Acanthostyle cross section circular, $0.09 \mathrm{~mm}$ diameter on average, composed of a large, light central lumen with laminae concentrically arranged around it; acanthoslyles developed in the outer exozone, mainly in the zoarium old zone; irregularly moniliform in longitudinal section and thickening autozooecial walls. Autozooecial walls laminated, with autozooecial boundary marked by dark granular layer, with a thickness of $0.05 \mathrm{~mm}$ on average in the exozone; autozooecial walls slightly wavy in the endozone with a thickness of $0.015 \mathrm{~mm}$ on average. Endozone and exozone well defined, with the endozone larger than the exozone (endozone with $2.2 \mathrm{~mm}$ diameter on average and exozone width $0.6 \mathrm{~mm}$ on average).

Discussion. - According to Ross's (1967b) emended diagnosis this zoarium can be placed in Eridotrypa because it shares with it the slender and circular zoarial branches with overgrowth, the oval or polygonal elongated autozooecial apertures, the mesozooecia developed in the exozone, the autozooecial angle with respect to the zoarial external surface, the distribution of the autozooecial diaphragms, and the number of mesozooecial diaphragms. However, the Iberian zoarium does not fit Ross's (1967b) emended diagnosis in having large acanthostyles in the exozone of the old zone of the zoarium, but I suggest adding this feature to Eridotrypa's diagnosis, since acanthostyles with similar diameter were described by Conti (1990) in Eridotrypa obliqua Conti, 1990, from the upper Katian of Sardinia. Moreover, the Iberian zoarium shares with this species the average angle with which autozooecia reach the external zoarial surface in the old zone of the colony (almost $90^{\circ}$ ), the distribution and density of the autozooecial diaphragms, and the low number of mesozooecia. Due to these shared characters, the Iberian zoarium is assigned to the Sardinian species.

Eridotrypa obliqua is similar to Eridotrypa abrupta Loeblich, 1942. Both species share the autozooecial angle with respect to the zoarial external surface and the presence of a dark layer marking the autozooecial boundary. But the two species can be distinguished because the autozooecia in Eridotrypa abrupta have cystiphragms, the mesozooecia are more numerous, and lack large acanthostyles.

Along the Mediterranean margin of Gondwana the following are also known: Eridotrypa constans Conti, 1990, described by Conti (1990) and Ernst \& Key (2007) from the upper Katian of Sardinia and the Montagne Noire (France), respectively; and Eridotrypa spicata Dreyfuss, 1948, identified by Dreyfuss (1948) and Ernst \& Key (2007) in the same Ordovician levels in the Montagne Noire. Eridotrypa constans can be distinguished from the Iberian Eridotrypa oblicua because the former has smaller zoaria, autozooecia with irregular cross sections in the inner endozone, and a higher density of autozooecial diaphragms in the endozone, but both species share the wavy autozooecial walls in the endozone. Eridotrypa spicata can be distinguished from the Iberian material because the former has smaller zoaria and more abundant acanthostyles. 

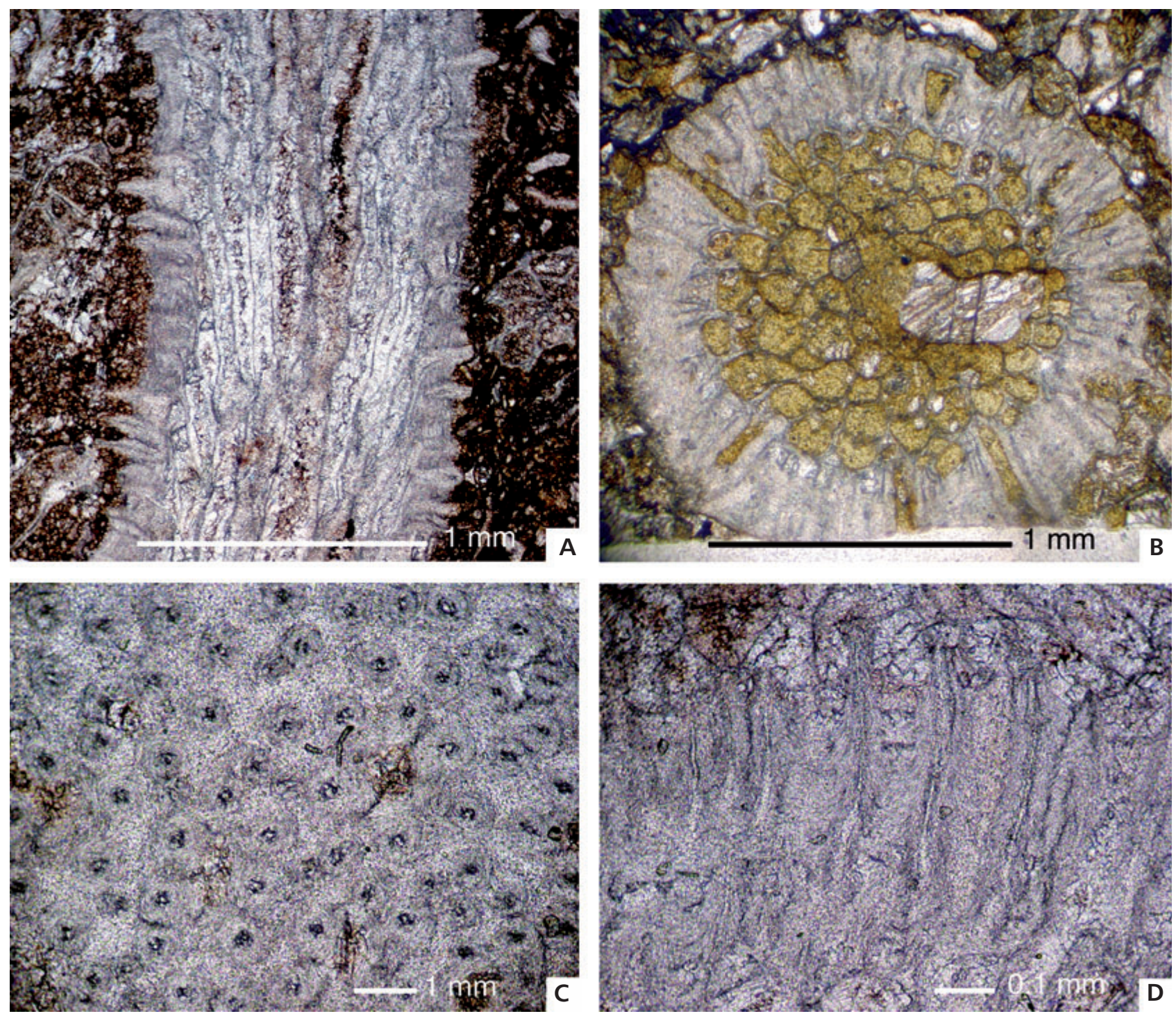

Figure 43. Trematopora acanthostylita sp. nov. • A - MPZ 2006/172 (holotype), longitudinal section. • B - MPZ 2006/173, transversal section. - C - MPZ 2006/169, detail of acanthostyles in tangential section. - D - MPZ 2006/170, detail of acanthostyles in longitudinal section. A, C and D from the La Peña Member in the La Peña del Tormo section, B from the La Peña Member in the Valdelaparra section (Fombuena, Zaragoza).

Occurrence. - Punta S'Argiola Member, lower part of the Domus-Novas Formation, upper Katian of Sardinia, Italy (Conti, 1990); the La Peña Member (layer 1), in the Valdelaparra section (Fombuena, Zaragoza).

\section{Genus Trematopora Hall, 1852}

Type species. - Trematopora tuberculosa Hall, 1852; Lower Silurian of North America.

\section{Trematopora acanthostylita sp. nov.}

Figures 39F, 43A-D, 44, 45, Table 24

2007 Jifarahpora sp.; Jiménez-Sánchez et al., fig. 6 (1, 2).
Holotype. - MPZ 2006/172.

Paratypes. - MPZ 2006/164-167, MPZ 2006/169, MPZ 2006/170, 171 and MPZ 2006/173, 174.

Type horizon. - La Peña Member of the Cystoid Limestone Formation, Upper Ordovician.

Type locality. - La Peña del Tormo Section (Fombuena, Zaragoza).

Material. - Five zoarial fragments in tangential section (MPZ 2006/164, 165, MPZ 2006/168, 169 and MPZ 2006/172); four zoarial fragments in transversal section (MPZ 2006/166, 167, MPZ 2006/170 and MPZ 2006/174); 


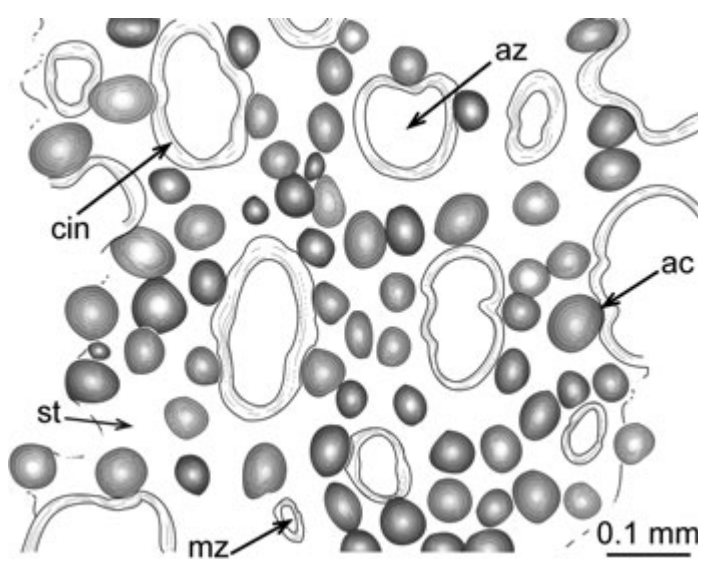

Figure 44. Trematopora acanthostylita $\mathrm{sp}$. nov. Schematic tangential section of the zoarium MPZ 2006/165 showing the large, abundant acanthostyles (ac) modifying autozooecial apertures (az) that are separated by an extensive extrazooecial skeleton (st), thickened cingulum in autozooecia (cin), and small mesozooecia (mz).

one zoarial fragment in transversal/tangential section (MPZ 2006/171); and one zoarial fragment in longitudinal section (MPZ 2006/173).

Etymology. - After the numerous, large acanthostyles present.

Diagnosis. - Trematopora characterized by the presence of numerous, large acanthostyles, by the small number of autozooecial diaphragms (absent in almost all autozooecia), and by the absence of diaphragms in mesozooecia.

Description. - Zoarial growth habit branching with branch cross section circular, $1.7 \mathrm{~mm}$ diameter on average. Nume-

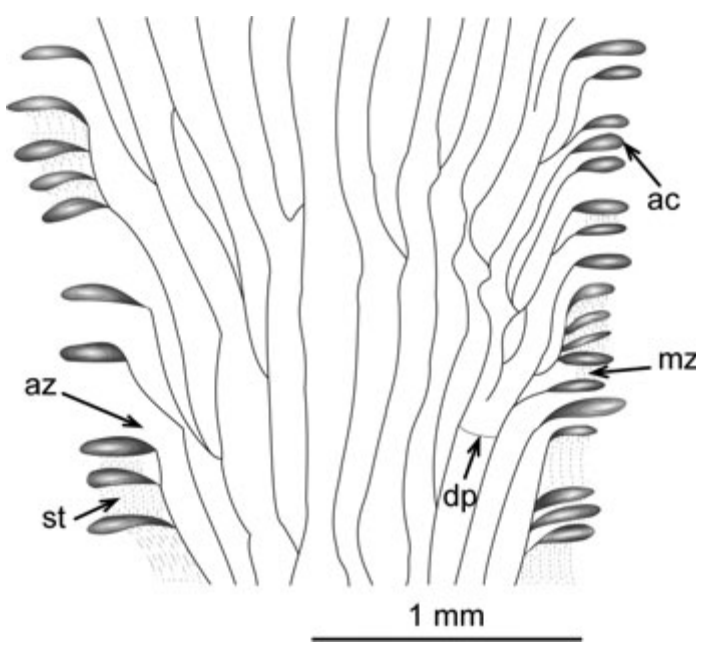

Figure 45. Trematopora acanthostylita sp. nov. Schematic longitudinal section of the holotype (MPZ 2006/172) showing the autozooecia (az) with occasional diaphragms (dp), the small mesozooecia (mz) covered by extrazooecial skeleton (st), and numerous acanthostyles (ac).

rous acanthostyles protruding from the external zoarial surface. Autozooecial apertures irregularly oval, some of them with petaloidal outline due to the acanthostyles, with large diameter of $0.09 \mathrm{~mm}$ on average; 1.3 autozooecial apertures per $\mathrm{mm}$ and 13 autozooecial apertures per $\mathrm{mm}^{2}$, separated by thickened extrazooecial laminated skeleton which is more than $0.09 \mathrm{~mm}$ thick; cingulum, $0.022 \mathrm{~mm}$ thick on average, present in autozooecial tubes. Autozooecia tubular, budding mainly in the axial zone, but with secondary budding in the outer endozone; autozooecia parallel to the growth direction of the branches in the endozone, at the endozone-exozone boundary, they strongly bend to

Table 24. Summary of the statistical analysis of Trematopora acanthostylita sp. nov. Abbreviations as in Table 1.

\begin{tabular}{|c|c|c|c|c|c|}
\hline Character & Or & $X$ & DS & $\mathrm{Nm}$ & Nsp \\
\hline Acanthostyles diameter (in mm) & $0.035-0.085$ & 0.07 & 0.02 & 47 & 6 \\
\hline Autozooecial large diameter (in mm) & $0.07-0.1$ & 0.09 & 0.01 & 67 & 6 \\
\hline Autozooecial wall thicknes in endozone (in $\mathrm{mm}$ ) & $0.005-0.015$ & 0.009 & 0.003 & 83 & 10 \\
\hline Autoooecial wall thickness in exozone (in mm) & $0.033-0.057$ & 0.041 & 0.008 & 26 & 6 \\
\hline Cingulum thickness (in mm) & $0.015-0.028$ & 0.022 & 0.004 & 25 & 7 \\
\hline Endozone diameter & $0.74-1.35$ & 1.1 & 0.2 & 39 & 10 \\
\hline Exozona thickness (in mm) & $0.24-0.54$ & 0.4 & 0.1 & 82 & 10 \\
\hline Mesozooecial diameter (in mm) & $0.05-0.07$ & 0.058 & 0.007 & 6 & 1 \\
\hline Number of acanthostyles per $1 \mathrm{~mm}$ & $6-11$ & 7.5 & 1.4 & 15 & 3 \\
\hline Number of acanthostyles per 1 square mm & $72-109.5$ & 90 & 17 & 5 & 3 \\
\hline Number of autozooecia per $1 \mathrm{~mm}$ & $0.5-1.5$ & 1.3 & 0.4 & 14 & 3 \\
\hline Number of autozooecia per 1 square $\mathrm{mm}$ & $12-14.5$ & 13 & 1 & 4 & 3 \\
\hline Number of mesozooecia per 1 square $\mathrm{mm}$ & $11-18$ & 18 & 12 & 3 & 1 \\
\hline Zoarial diameter (in mm) & $1.2-2.67$ & 1.7 & 0.4 & 36 & 10 \\
\hline
\end{tabular}


reach the zoarial external surface at an angle of $90^{\circ}$. Autozooecial diaphragms absent or scarce. Autozooecial cross section irregularly polygonal in the endozone. Mesozooecia developed at the endozone-exozone boundary, overlaid by a thick extrazooecial skeleton and only observed in deep tangential section; mesozooecia with subcircular or subpolygonal shapes and $0.058 \mathrm{~mm}$ diameter on average, located between autozooecia or in small groups forming maculae with an average density of 18 mesozooecia per $\mathrm{mm}^{2}$; mesozooecial diaphragms absent. Acanthostyles with large diameter ( $0.07 \mathrm{~mm}$ on average), composed of a light central hyaline lumen surrounded by dark laminae; high density of acanthostyles ( 90 acanthostyles per $\mathrm{mm}^{2}$ and 7.5 acanthostyles per mm), mostly developed in the inner exozone, but some in the outer endozone. Autozooecial walls in the exozone $0.041 \mathrm{~mm}$ thick on average, with an inverse $\mathrm{V}$ pattern, but with laminas strongly influenced by the presence of acanthostyles; autozooecia walls in the endozone slightly wavy with a thickness of $0.009 \mathrm{~mm}$ on average. Endozone with an average diameter of $1.1 \mathrm{~mm}$ and the exozone with an average width of $0.4 \mathrm{~mm}$, both well defined.

Discussion. - Following Ernst \& Key's (2007) diagnosis, these zoaria share with the genus Trematopora the branching growth habit, the autozooecial oval cross section and the scarce number of diaphragms in the autozooecia, the presence of mesozooecia covered by a laminated skeleton, the abundance of acanthostyles around autozooecial apertures, and the thickness of zooecial walls both in the endozone and exozone. The Iberian zoaria mesozooecia lack diaphragms, a feature included in Ernst \& Key's (2009) diagnosis, although they defined Trematopora gracile as a species lacking mesozooecial diaphragms. So, I suggest changing "Abundant mesozooecia with abundant diaphragms..." to "Abundant mesozooecia, which may have diaphragms..." in the diagnosis of the genus by Ernst \& Key's (2009).

Trematopora tuberculosa Hall, 1852, Trematopora sardoa (Vinassa de Regny, 1942), and Trematopora gracile Ernst \& Key, 2007 from the upper Katian of Montagne Noire (France), Sardinia and the Carnic Alps (Italy) [see Conti (1990) and Ernst \& Key (2007)] as well as Trematopora minima Suttner \& Ernst, 2007 from the upper Katian of India, are other species of the genus previously described from the Mediterranean Province (JiménezSánchez \& Villas in press). Trematopora acanthostylita sp. nov. is most similar to Trematopora gracile but they can be distinguished because in the former the autozooecial diaphragms are practically absent both in the endozone and in the exozone and it has a larger zoarial diameter (1.20-2.67 mm in Trematopora acanthostylita sp. nov. vs. 0.44-1.68 $\mathrm{mm}$ in Trematopora gracile). Trematopora acanthostylita sp. nov. is also similar to Trematopora sardoa, but they can be easily distinguished because the latter has abundant diaphragms in the mesozooecia.
Occurrence. - This species is known from its type locality and in the La Peña Member (layer 1) in the Valdelaparra section (Fombuena, Zaragoza).

\section{Acknowledgements}

I would like to thank Enrique Villas for his help and advice in the development of this work, to Javier Gómez for improving the standard of English, and to Andrej Ernst for his advice on systematics and his thorough revision of the paper; and also to Françoise P. Bigey for her thorough revision. This research has been funded by the Spanish Ministry of Science, Project CGL 2006-11176. This is a contribution to IGCP 503 Ordovician Paleogeography and Paleoclimate.

\section{References}

ANNOSCIA, E. 1968. Briozoi. Introduzione allo studio con particolare riguardo al Briozoi Italiani e Mediterranei. Palaeontographica Italica, Special Volume, 1-397.

ASTROVA, G.G. 1964. O novom otryade paleozoyskych mshanok [A new order of Paleozoic Bryozoa]. Paleontologicheskii Zhurnal 2, 22-31. [in Russian]

ASTROVA, G.G. 1965. Morphologiya, istoriya razvitiya i sistema Ordovikskiych i Siluriyskiych Mshanok. [Morphology, historical development and systematics of Ordovician and Silurian Bryozoa]. Trudy Paleontologicheskogo Instituta 106, 1-422. [in Russian].

ASTROVA, G.G. 1978. Istoriya razvitiya, sistema i Pilogeniya mshanok [Historical development, systematics and phylogeny of Bryozoa. Order Trepostomata]. Trudy Paleontologischeskogo Instituta Akademiya Nauk SSSR 169, 1-240. [in Russian].

ASTROVA, G.G. \& MorozovA, I.P. 1956. K sistematike mshanok Otryada Cryptostomata [Systematics of Bryozoa of the Order Cryptostomata]. Doklady Akademii Nauk S.S.S.R 110, 661-664. [in Russian]

BASSLER, R.S. 1911. The early Paleozoic Bryozoa of the Baltic provinces. United States National Museum Bulletin 77, 1-382.

BASSLER, R.S. 1913. Bryozoa, 314-355. In ZITTEL, K.A. \& EASTMAN, C.R. (eds) Text-book of Paleontology. $2^{\text {nd }}$ edition. MacMillan \& Co., London.

BASSLER, R.S. 1927. Bryozoa [Silurian, Anticosti]. Canadian Geological Survey Memoir 154, 143-168.

BASSLER, R.S. 1952. Taxonomic notes on genera of fossil and Recent Bryozoa. Journal of the Washington Academy of Science 42, 381-385.

BLAKE, D.B. 1983. The Order Cryptostomata, 440-452. In Boardman, R.S., Cheetham, A.H., Blake, D.B, UtGAARD, J., KARKLINS, O.L., COOK, P.L., SANDBERG, P.A., LUTAUD, G. \& WoOD, T.S. (eds) Bryozoa. Treatise on Invertebrate Paleontology, Part G, Revised. Geological Society of America \& University of Kansas, Boulder \& Lawrence.

BoArdman, R.S. \& CheEtham, A.H. 1973. Degrees of Colony Dominance in Stenolaemate and Gymnolaemate Bryozoa, 121-220. In BOARDMAN, R.S., CHEETHAM, A.H. \& OLIVER, W.A. JR. (eds) Animal colonies. Development and Function 
through time. Dowden, Hutchinson \& Ross Inc., Stroudsberg, Pennsylvania.

BORG, F. 1926. Studies on Recent cyclostomatous Bryozoa. Zoologiska Bidrag från Uppsala 10, 181-507.

BoCK, F. 2009. http://www.nhm.ac.uk/hosted_site/iba/bryozoa_ home_page/famsys.html

Boulange, M.F. 1963. Sur quelques espèces nouvelles de bryozoaires de l'Ordovicien Supérieur de la Montagne Noire. Bulletin de la Société géologique de France 7(5), 34-40.

BROOD, K. 1970. On two species of Saffordotaxis (Bryozoa) from the Silurian of Gotland, Sweden. Stockholm Contributions in Geology 21(5), 57-68.

BROOD, K. 1973. Palaeozoic Cyclostomata (a preliminary report), 247-256. In LARWOOD, G.P. (ed.) Living and Fossil Bryozoa. Academic Press, London.

BROOD, K. 1974. Cyclostomatous Bryozoa from the Kullsberg Limestone. Geologiska Föreningens i Stockholm Förhandlingar 96(4), 423-425.

BROOD, K. 1975a. Cyclostomatous Bryozoa from the Silurian of Gotland. Stockholm Contributions in Geology 28, 45-119.

Brood, K. 1975b. Paleoecology of Silurian Bryozoa from Gotland (Sweden), 401-414. In POUYET, S. (ed.) Bryozoa 74. Documents des Laboratoires de Géologie de la Faculté des Sciences de Lyon, HS 3.

Busk, G. 1852. Catalogue of marine Polyzoa in the collection of the British Museum. I. Cheilostomata. $54 \mathrm{pp}$. Trustees of the British Museum (Natural History), London.

ButTLER, C.J. 1989. New information on the morphology and skeletal ultrastructure of the Ordovician cyclostome bryozoan Kukersella Toots, 1952. Paläontologisches Zeitschrift 63, 215-227.

BUTTLER, C.J. 1991a. A new Upper Ordovician bryozoan fauna from the Slade and Redhill Beds, South Wales. Palaeontology 34(1), 77-108.

BUTTLER, C.J. 1991b. Bryozoans from the Llanbedrog Mudstones (Caradoc), north Wales. Bulletin of the British Museum, Natural History, Geology 47, 153-168.

ButTLER, C.J., CHERnS, L. \& MASSA, D. 2007. Bryozoan mudmounds from the Upper Ordovician Jifarah (Djeffara) Formation of Tripolitania, north-west Libya. Palaeontology 50(2), 479-494. DOI 10.1111/j.1475-4983.2007.00636.x

ButTler, C.J. \& MASSA, D. 1996. Late Ordovician bryozoans carbonate buildups, Tripolitania, Libya, 63-68. In GORDON, D.P., SMITH, A.M. \& GRANT-MACKIE, J.A. (eds) Bryozoans in Space and Time (Proceeding of the $10^{\text {th }}$ International Bryozoology Conference, Victoria University of Wellington, New Zealand). Niwa, Wellington.

CONTI, S. 1990. Upper Ordovician Bryozoa from Sardinia. Palaeontographia Italica 77, 85-165.

ConTI, S. \& SERPAGLI, E. 1987. Funtional morphology of the cap-like apparatus in autozooids of a Palaeozoic trepostome bryozoan. Lethaia 20(1), 1-20. DOI 10.1111/j.1502-3931.1987.tb00754.x

CONTI, S. \& SERPAGLI, E. 1988. Bimineralic (calcareous and phosphatic) skeleton in Late Ordovician Bryozoa from Sardinia: geological implication. Bolletino della Società Paleontologica Italiana 27(2), 129-162.

DEREIMS, A. 1898. Recherches géologiques dans le sud de l'Aragón. 199 pp. Thesis Faculté des Sciences, Paris.

Destombes, J., TERMier, H. \& TERMIER, G. 1971. Sur quelques
Bryozoaires ectoproctes de l'Ordovicien supérieur du Sud marocain. Notes et Mémoires. Service Geologique du Maroc 31(237), 61-64.

DREYFUSS, M. 1948. Contribution à l'etude géologique et paléontologique de l'Ordovicien supérieur de la Montagne Noire. Mémoires de la Société Geologique de France 58, 1-62.

DZIK, J. 1981. Evolutionary relationships of the Early Paleozoic Cyclostomatous Bryozoa. Palaeontology 24(4), 827-861.

EhrenberG, C.G. 1831. Symbolae Physicae, seu Icones et descriptiones Corporum Naturalium novarum aut minus cognitorum, quae ex itineribus per Libyam, Agyptum, Nubiam, Dagalam, Syriam, Arabiam et Habessiniam publico institutis sumptu, studio annis 1820-25, redierunt. Pars Zoologica, vol. 4 Animalia Evertebrata exclusis Insectis. 831 pp., 10 pls. Mittler, Berlin.

EICHWALD, E. 1840. Die Urwelt Russlands, durch Abbildungen erlauertet. 106 pp. Druckerei des Journal de Saint-Pétersbourg, St. Petersburg.

EICHWALD, E. 1855-1860. Lethaea Rossica ou Paléontologie de la Russie. 1 Ancienne Periode. Bryozoa, 355-494. E. Schweizerbart, Stuttgart.

ERnST, A. \& CARRERA, M. 2008. Cryptostomid bryozoans from the Sassito Formation, Upper Ordovician cool-water carbonates of the Argentinean Precordillera. Palaeontology 51(5), 1117-1127. DOI 10.1111/j.1475-4983.2008.00802.x

ERnST, A. \& KEY, M. 2007. Upper Ordovician bryozoa from the Montagne de Noire, Southern France. Journal of Systematic Palaeontology 5(4), 359-428.

DO] $10.1017 /$ S1477201907002155

FARMER, G.T. 1975. New bifoliate tubular bryozoan genera from the Simpson Group (Middle Ordovician), Arbuckle Mountains, Oklahoma. Bulletins of American Paleontology 67(287), 123-138.

GoldFuss, G.A. 1831. Petrefacta Germaniae. Abbildung und Beschreibung der Petrefacten Deutschlands und angrenzender Länder. Band 1, Lieferung 3, 165-240. Aznz \& Co, Düsseldorf.

GoRJunOVA, R.V. 1985. Morfologya, Sistema i Filogenya Mshanok (Otryad Rhabdomesida). The morphology, systematics and phylogeny of Bryozoa (Order Rhabdomesida). Trudy Paleontologischeskogo Instituta Akademiya Nauk SSSR 208, 1-140. [in Russian]

GORJUNOVA, R.V. 1987. Puti kolonial'noi integratsii paleozoiskikh mshanok, 45-69. In MorozovA, I.P. (ed.) Mofogenez $i$ puti razvitiya kolonial'nosti mshanok $i$ kishechnopolostiykh. Trudy Palaeontologischeskogo Instituta 222.

GoRJunOVA, R.V. 2005. Ralfimartitidae, a new family of Paleozoic Bryozoans of the Order Trepostomida. Paleontologicheskii Zhurnal 2, 158-172.

GorJunOVA, R.V. \& LAVRENTJEVA, V.D. 1987. Novye rod Prophyllodictya drevneyshiy predstavitel' kriptostomidnykh mshanok [The new genus Prophyllodictya - the most ancient representative of cryptostome Bryozoa]. Paleontologicheskii Zhurnal 1, 41-51. [in Russian]

GUTIÉRREZ-MARCO, J.C., ROBARDET, M., RÁBANO, I., SARMiento, G.N., SAN José, M.A., Herranz, P. \& Pieren, A.P. 2002. Ordovician, 31-49. In GiBBONS, W. \& MORENO, T. (eds) The Geology of Spain. The Geological Society, London.

HAFENRICHTER, M. 1979. Paläontologisch-Ökologische und Lithofazielle Untersuchungen des "Ashgill-Kalkes" (Jung- 
ordovizium) in Spanien. Arbeiten aus dem Paläontologischen Institut Würzburg 3, 1-139.

HALL, J. 1851. New genera of fossil corals from the report by James Hall, on the Paleontology of New York, 398-401. In Silliman, B., Silliman, B. Jr. \& DANA, J.D. (eds) The America Journal of Science Arts, Washington, serie 2(11).

HALL, J. 1852. Palaeontology of New York v. 2. Contaning descriptions of the Organic remains of the Lower middle division of the New York system. Natural History of New York 6(2), $40-52$.

HAMmANN, W. 1992. The Ordovician trilobites from the Iberian Chains in the province of Aragón, NE-Spain. I. The trilobites of the Cystoid Limestone (Ashgill Series). Beringeria 6, 1-219.

HAMMER, Ø., HARPER, D.A.T. \& RYAN, P.D. 2008. PAST v 1.81. Paleontological Statistics Software: Package for Education and Data Analysis.

HENNIG, A.H. 1908. Gotlands Silur-Bryozoer, 3. Arkiv för zoologi $4(21), 1-64$.

HILlMER, G. \& SCHALLREUTER, R. 1987. Ordovician bryozoans from erratic boulders of Northern Germany and Sweden, 113-119. In RosS, J.R.P. (ed.) Bryozoa: Present and past. Western Washington University, Bellingham, Washington.

JAROSHINSKAJA, A.M. 1962. Some representatives of the bryozoan family Monticuliporidae in the Upper Ordovician of the Altái Mountains (in Russian). Trudy Sibirskogo nauchnoisledovatelskogo instituta geologii, geofiziki i mineralnogo syrya (SNIIGGIMS) 23, 143-149.

JIMÉNEZ-SÁNCHEZ, A. In press. New Monticuliporidae (Bryozoa Trepostomata) from the Cystoid Limestone Formation (Upper Ordovician) of the Iberian Chains (NE Spain). Geodiversitas.

JimÉneZ-SÁncheZ, A., SpJeldnaes, N. \& Villas, E. 2007. Ashgill bryozoans from the Iberian Chains (NE Spain) and their contribution to the Late Ordovician biodiversity peak in North Gondwana. Ameghiniana 44(4), 681-696.

JIMÉNEZ-SÁNCHEZ, A., ANSTEY, R.L. \& AZANZA, B. Description and phylogenetic analysis of Iberostomata fombuenensis new genus and species (Bryozoa Ptilodictyina). To be published.

JIMÉNEZ-SÁNCHEZ, A. \& VILLAS, E. In press. The bryozoan dispersion into the Mediterranean margin of Gondwana during the pre-glacial Late Ordovician. Palaeogeography, Palaeoclimatology, Palaeoecology.

DOI 10.1016/J.palaeo.2009.11.027

KARKLINS, O.L. 1983. Systematic descriptions for the Suborder Ptilodictyina, 489-529. In BOARDMAN, R.S., CHEETHAM, A.H., Blake, D.B., UtgaArd, J., Karklins, O.L., CoOK, P.L., SANDberG, P.A., Lutaud, G. \& Wood, T.S. (eds) Bryozoa. Treatise on Invertebrate Paleontology Part G, Revised. Geological Society of America \& University of Kansas, Boulder \& Lawrence.

KARKLINS, O.L. 1984. Trepostome and Cystoporate Bryozoans from the Lexington Limestone and the Clays Ferry Formation (Middle and Upper Ordovician) of Kentucky. U.S. Geological Survey Professional Paper 1066(I), 1-105.

KEY, M.M. JR. 1991. The halloporid trepostome bryozoans from the Ordovician Simpson Group of Oklahoma. Journal of Paleontology 65(2), 200-212.

KeTtNeR, R. 1913. O novém nalezišti bryozoí a jiných zkamenělin spodního siluru na Pernikářce u Košír. Rozpravy České akademie císaře Frantǐska Josefa pro vědy, slovesnost a umění, Tř́da II (mathematicko-přirodnická) 22(5), 1-22.
LavrentjeVA, V.D. 1985. Mshanki podotryda Phylloporina. [Bryozoans of the suborder Phylloporina]. Trudy Paleontologischeskogo Instituta Akademiya Nauk SSSR 214, 1-102. [in Russian]

LOBDELL, F.K. 1992. Arthrostylidae (Bryozoa: Cryptostomata) from the Gunn Member, Stony Mountain Formation (Upper Ordovician), North Dakota and Manitoba. North Dakota Geological Survey Miscellaneous Series 76, 99-115.

LoEBLICH, A.R. 1942. Bryozoan from the Ordovician Bromide Formation, Oklahoma. Journal of Paleontology 16(4), 413-436.

MCKinNeY, F.K. 1971. Trepostomatous Ectoprocta (Bryozoa) from the lower Chickamauga Group (Middle Ordovician), Wills Valley, Alabama. Bulletin of American Paleontology 60, 195-337.

MCKINNEY, F.K. 1977. Autozooecial budding patterns in dendroid Paleozoic bryozoans. Journal of Paleontology 51(2), 303-329.

MENEGHINI, G. 1880. Nuovi fossili siluriani di Sardegna. Memorie della reale Accademia dei Lincei ser. 3(5), 216-229.

MILLER, S.A. 1889. North American Geology and Paleontology. 664 pp. Western Methodist Book Concern, Cincinnati.

MiLLER, S.A. \& DYER, C.B. 1878. Contributions to paleontology. Cincinnati. Journal of the Cincinnati Society of Natural History 2, 1-11.

MODZALEVSKAYA, E.A. 1953. Trepostomaty ordovika Pribaltiki i ikh stratigraficheskoje znachenije [Trepostomata of the Ordovician of the East Baltic and their stratifraphic significance]. Trudy Vsesojuznogo Nefdtjanogo Nauchno-Issledovatelskogo Geologo-Razvedochnogo Instituta (VNIGRI) 78, 91-167. [in Russian]

MOROZOVA, I.P. 2001. Mshanki otryada Fenesellida (morfologya sistema, istoricheskoe razvitie) [Bryozoans of the Order Fenestellida (morphology, system, historical development]. Trudy Paleontologischeskogo Instituta 277, 1-176. [in Russian]

NeKHOROSHEV, V.P. 1936. New discovery of Silurian Bryozoa. Transactions of the Central Geological and Prospecting Institute of the SSSR 61, 1-40. [in Russian]

NeKHoRosheV, V.P. 1956. Class Bryozoa. In Materialy po paleontologi. Novye semetstva i rody. Vsesoyuzniy NauchnoIssledovatelskiy Geologicheskiy Institut min. Geol. Okran. Nedr. SSSR (VSEGEI) 12, 42-49. [in Russian]

NiCHOLSON, H.A. 1879. On the structure and affinities of the "tabulate corals" of the Paleozoic Period, with critical descriptions of illustrative specie. 342 pp. William Blackwood and sons, Edinburgh.

NICKLES, J.M. \& BASSLER, R.S. 1900. A synopsis of American fossil Bryozoa, including bibliography and synonymy. United States Geological Survey Bulletin 173, 1-663.

ORBIGNY, A. D' 1850. Note sur quelques espèces nouvelles de Bryozoaires fossiles des terrains crétacés de la France. Espèces de l'étage cénomanien ou de la craie chloritée. Revue et Magazine de Zoologie pure et appliquée 2(2), 170-181.

PANDER, C.H. 1830. Beiträge zur Geognosie des russischen Reiches. 165 pp. K. Kray, St. Petersburg.

POČTA, P. 1902. Anthozoaires et Alcyonaires. In BARRANDE, J. Système silurien du centre de la Bohême 8(2). 347 pp. Prague.

PRANTL, F. 1940a. Note préliminaire sur les Bryozoaires ordoviciens de la Montagne Noire. Věstník Králowské České společnosti nauk 9, 1-2. 
PRANTL, F. 1940b. Ordovické a silurské mechovsky z Montagne Noire (Languedock). Some Ordovician and Silurian Bryozoa from Montagne Noire (Languedock). Sborník Národního musea v Praze, Acta Musei nationalis Praguae, 2B(4) Geologia et Paleontologia 2, 81-106. [in Czech]

PUSHKIN, V.I. 1981. A review of the genus Calloporella. Paleontologicheskii Zhurnal, 67-75. [in Russian]

PUSHKIN, V.I. 1987. Structure of communities of Ordovician bryozoans in the Baltic Basin. Paleontology and reconstruction of geological history of paleobasins. Proceedings of XXIX session of the All-Union Paleontological Society [Vsesoyuznoe Paleontologicheskoe Obschestvo], 45-49.

ROEMER, C.F. von 1876. Lethaea Geognostica oder Beschreibung und Abbildung der fur die Gebirgs-Formationen bezeichnendsten Versteinnerungen. Theil 1. Lethaea Palaeozoica. Volume 1, Atlas. J.C. Henzler, Stuttgart.

RÖHLICH, P. 1957. Stratigrafie a vývoj bohdaleckých vrstev středočeského ordoviku. Sborník Ústředního ústavu geologického, Oddíl geologický 23(2), 373-439. [in Czech]

Ross, J.R.P. 1967a. Champlainian Ectoprocta (Bryozoa), New York State. Journal of Paleontology 41(3), 632-648.

Ross, J.R.P. 1967b. Evolution of ectoproct genus Prasopora in Trentonian time (Middle Ordovician) in northern and central United States. Journal of Paleontology 41(2), 403-416.

Ross, J.R.P. 1970. Distribution, paleoecology, and correlation of Champlainian Ectoprocta (Bryozoa), New York State, Part III. Journal of Paleontology 44(2), 346-382.

SHARPE, D. 1853. Description of the New Species of Zoophyta and Mollusca, 146-158. In Ribeiro, S.C., SHARPE, C.D. \& JONES, T.R. (eds) Carboniferous and Silurian Formations of the neighbourhood of Russaco in Portugal. Quarterly Journal of the Geological Society, London 9, Appendix B, 135-160.

SingH, R.J. 1979. Trepostomatous bryozoan fauna from the Bellevue Limestone, Upper Ordovician in the tri-state area of Ohio, Indiana and Kentucky. Bulletin of American Paleontology 76(307), 161-288.

SPJELDNAES, N. 1984. Epifauna as a tool in autecological analysis of Silurian brachiopods. Special Papers in Palaeontology 32, 225-235.

SUTTNER, T.J. \& ERNST, A. 2007. Upper Ordovician bryozoans of the Pin Formation (Spit Valley, Northern India). Palaeontology 50(6), 1485-1518. DOI $10.1111 / \mathrm{j} .1475-4983.2007 .00726 . x$

TERMIER, H. \& TERMIER, G. 1950. Paléontologie marocaine. II: Invertebrés de l'Ere Primaire, 2, Bryozoaires et Brachiopodes. 254 pp. Hermann a Cie, Paris.

Toots, H. 1952. Bryozoen des estnischen Kuckersits. Mitteilungen aus dem Geologischen Staatsinstitut in Hamburg 21, 113-117.

ULRICH, E.O. 1878. Descriptions of some new species of fossils from the Cincinnati Group. The Journal of the Cincinnati Society of Natural History 1, 92-100.

ULRICH, E.O. 1882. American Palaeozoic Bryozoa. The Journal of the Cincinnati Society of Natural History 5, 121-175, 232-257.

ULRICH, E.O. 1886. Report on the Lower Silurian Bryozoa with preliminary descriptions of some of the new species. Minnesota Geology and Natural History Survey Annual Report $14^{\text {th }}$ 1885, 57-103.

ULRICH, E.O. 1889. On some Polyzoan (Bryozoa) and Ostracoda from the Cambro-Silurian Rocks of Manitoba. Geological Natural History Survey Canada, Contributions to the micro-palaeontology of the Cambro-Silurian rocks of Canada 2, 22-57.

ULRICH, E.O. 1890. Palaeontology of Illinois. Section VI. Palaeozoic Bryozoa. Part II. Report of the Geological Survey of Illinois 8, 283-688.

ULRICH, E.O. 1893. On Lower Silurian Bryozoa of Minnesota. Minnesota Geology and Natural History Survey. Final Report 3(1), 96-332.

UTGAARD, J. 1968. A revision of North American genera of ceramoporoid bryozoans (Ectoprocta): Part II: Crepipora, Ceramoporella, Acanthoceramoporella, and Ceramophylla. Journal of Paleontology 42(6), 1444-1455.

UTGAARD, J. 1969. A revision of North American genera of ceramoporoid bryozoans (Ectoprocta): Part III: the ceramoporoid genera Ceramopora, Papillalunaria, Favositella, and Haplotrypa. Journal of Paleontology 43, 289-297.

Vennin, E., Alvaro, J.J. \& Villas, E. 1998. High-latitude pelmatozoan-bryozoan mud-mounds from the Late Ordovician northern Gondwana platform. Geological Journal 3, 121-140. DOI 10.1002/(SICI)1099-1034(1998040)33:2<121::AID-GJ780 $>3.0 . \mathrm{CO} ; 2-\mathrm{D}$

VILLAS, E. 1983. Las formaciones del Ordovícico Medio y Superior de las Cadenas Ibéricas y su fauna de braquiópodos. Estudios geológicos 39, 359-377.

VILlAS, E. 1985. Braquiópodos del Ordovícico Medio y Superior de las Cadenas Ibéricas Orientales. Memorias del Museo Paleontológico de la Universidad de Zaragoza 1, 1-223.

Vinassa De Regny, P. 1910. Fossili Ordoviciani del Nucleo Centrale Carnico. Atti della Accademia Gioenia di Scienze Naturali in Catania, Serie V 3, Mem. XII, 1-48.

VINASSA DE REGNY, P. 1914. Fossili ordoviciani di Uggwa (Alpi Carniche). Memorie dell'Instituto Geologico della R. Universitetà di Padora 2, 195-221.

VinASSA DE REgNY, P. 1915. Fossili Ordoviciani del Capolago (Seekopf) presso il passo di Volaia (Alpi Carniche). Palaeontographia Italica 21, 97-117.

VINASSA DE REGNY, P. 1942. Fossili Ordoviciani sardi, Parte II. Atti delle Reale Accademia Italiana, Memorie di Scienze Fisiche, Matematiche e Naturale 12, 1025-1055.

VINE, G.R. 1884. Fourth report of the Committee, consisting of Dr. H. C. Sorby and Mr. G. R. Vine, appointed for the purpose of reporting on fossil Polyzoa. The British Association for the Advancement of Science, Report 53d, Meeting (Southport, 1883), 161-209.

VINE, G.R. 1886. Notes on the Yorekdale Polyzoa of North Lancashire. Proceedings of the Yorkshire Geological Society, New Series 9, 70-98.

XiA, F.S., ZHANG, S.G. \& WANG, Z.Z. 2007. The oldest Bryozoans: new evidence from the Late Tremadocian (Early Ordovician) of East Yangtze Gorges in China. Journal of Paleontology 81(6), 1308-1326. DOI 10.1666/04-128.1 